Prepared in cooperation with the California State Water Resources Control Board A product of the California Groundwater Ambient Monitoring and Assessment (GAMA) Program

\title{
Groundwater-Quality Data in the Santa Barbara Study Unit, 2011: Results from the California GAMA Program
}






\section{Cover photographs:}

Top right: Bridge over Rincon Creek in Carpinteria, California. (Photograph taken by Tracy Davis, U.S. Geological Survey.)

Bottom right: Well facing Santa Ynez Mountains, California. (Photograph taken by Carmen Burton, U.S. Geological Survey.) 


\section{Groundwater-Quality Data in the Santa Barbara Study Unit, 2011: Results from the California GAMA Program}

By Tracy A. Davis, Justin T. Kulongoski, and Kenneth Belitz

A product of the California Groundwater Ambient Monitoring and Assessment (GAMA) Program

Prepared in cooperation with the California State Water Resources Control Board

Data Series 742 


\title{
U.S. Department of the Interior SALLY JEWELL, Secretary
}

\section{U.S. Geological Survey Suzette M. Kimball, Acting Director}

\author{
U.S. Geological Survey, Reston, Virginia: 2013
}

For more information on the USGS - the Federal source for science about the Earth, its natural and living resources, natural hazards, and the environment, visit http://www.usgs.gov or call 1-888-ASK-USGS.

For an overview of USGS information products, including maps, imagery, and publications, visit http://www.usgs.gov/pubprod

To order this and other USGS information products, visit http://store.usgs.gov

Any use of trade, product, or firm names is for descriptive purposes only and does not imply endorsement by the U.S. Government.

Although this report is in the public domain, permission must be secured from the individual copyright owners to reproduce any copyrighted materials contained within this report.

Suggested citation:

Davis, T.A., Kulongoski, J.T., and Belitz, Kenneth, 2013, Groundwater-quality data in the Santa Barbara study unit, 2011—Results from the California GAMA Program: U.S. Geological Survey Data Series 742, 72 p. 


\section{Contents}






\section{Figures}

1. Map showing hydrogeologic provinces of California and the location of the Santa Barbara study unit, California GAMA Priority Basin Project

2. Map showing the boundaries of California Department of Water Resources groundwater basins in the Santa Barbara study unit and the locations of counties, major cities, major roads, topographic features, and hydrologic features and geologic map of the Santa Barbara Coastal Plain showing major faults and hydrologic features, Santa Barbara study unit, California GAMA Priority Basin Project

3. Maps showing the distribution of the grid cells and the location of public-supply wells from the California Department of Public Health database, and the distribution of grid cells, the location of sampled grid and understanding wells, Santa Barbara study unit, California GAMA Priority Basin Project

\section{Tables}

1. Identification, sampling, and construction information for wells sampled for the Santa Barbara study unit, January to February 2011, California GAMA Priority Basin Project.

2. Classes of chemical constituents and field water-quality indicators collected for the Santa Barbara study unit, January to February 2011, California GAMA

Priority Basin Project.

3A. Volatile organic compounds, primary uses or sources, comparative benchmarks, and reporting information for the USGS National Water Quality Laboratory Schedule 2020 .

3B. Pesticides and pesticide degradates, primary uses or sources, comparative benchmarks, and reporting information for the USGS National Water Quality Laboratory Schedule 2003.

3C. Polar pesticides and degradates, primary uses or sources, comparative thresholds, and reporting information for the USGS National Water Quality Laboratory Schedule 2060.

3D. Pharmaceutical compounds, primary uses or sources, comparative benchmarks, and reporting information for the USGS National Water Quality Laboratory Schedule 2080.

3E. Constituents of special interest, primary uses or sources, comparative benchmarks, and reporting information for Weck Laboratories, Inc., City of Industry, California, analyses.

3F. Trace elements, comparative benchmarks, and reporting information for the USGS National Water Quality Laboratory Schedule 1948.

3G. Nutrients, comparative benchmarks, and reporting information for the USGS National Water Quality Laboratory Schedule 2755.

$3 \mathrm{H}$. Major and minor ions, silica, total dissolved solids, and alkalinity, comparative benchmarks, and reporting information for the USGS National Water Quality Laboratory Schedule 1948.

31. Arsenic, chromium, and iron species, comparative benchmarks, and reporting information for the USGS Trace Metal Laboratory, Boulder, Colorado, analyses. 


\section{Tables-Continued}

3J. Isotope tracers and radioactive constituents, comparative benchmarks, and

reporting information for laboratory analyses. ................................ 33

3K. Dissolved gases and isotope tracers, comparison benchmarks, and reporting information for Lawrence Livermore National Laboratory. ....................... 33

4. Water-quality indicators in samples collected for the Santa Barbara study unit, January to February 2011, California GAMA Priority Basin Project. ...

5. Volatile organic compounds detected in samples collected for the Santa Barbara study unit, January to February 2011, California GAMA Priority Basin Project.

6. Pesticides and pesticide degradates detected in samples collected for the Santa Barbara study unit, January to February 2011, California GAMA Priority Basin Project.

7. Perchlorate detected in the samples collected for the Santa Barbara study unit, January to February 2011, California GAMA Priority Basin Project. ...

8. Trace elements detected in the samples collected for the Santa Barbara study unit, January to February 2011, California GAMA Priority Basin Project.

9. Nutrients detected in samples collected for the Santa Barbara study unit, January to February 2011, California GAMA Priority Basin Project. ...

10. Major and minor ions, silica, and total dissolved solids detected in samples collected for the Santa Barbara study unit, January to February 2011, California GAMA Priority Basin Project.

11. Arsenic, chromium, and iron species detected in samples collected for the Santa Barbara study unit, January to February 2011, California GAMA Priority Basin Project.

12. Results for analyses of stable isotope ratios, tritium activity, and carbon-14 abundance detected in samples collected for the Santa Barbara study unit, January to February 2011, California GAMA Priority Basin Project. ...

13A. Radon-222 detected in samples collected for the Santa Barbara study unit, January to February 2011, California GAMA Priority Basin Project....

13B. Gross alpha and gross beta radioactivity detected in samples collected for the Santa Barbara study unit, January to February 2011, California GAMA Priority Basin Project. 


\section{Conversion Factors}

\section{Inch/Pound to SI}

\begin{tabular}{|c|c|c|}
\hline Multiply & By & To obtain \\
\hline \multicolumn{3}{|c|}{ Length } \\
\hline inch (in.) & 2.54 & centimeter $(\mathrm{cm})$ \\
\hline inch (in.) & 25.4 & millimeter (mm) \\
\hline foot $(\mathrm{ft})$ & 0.3048 & meter (m) \\
\hline mile (mi) & 1.609 & kilometer (km) \\
\hline \multicolumn{3}{|c|}{ Area } \\
\hline square mile $\left(\mathrm{mi}^{2}\right)$ & 2.590 & square kilometer $\left(\mathrm{km}^{2}\right)$ \\
\hline \multicolumn{3}{|c|}{ Volume } \\
\hline ounce, avoirdupois (oz) & 28.35 & $\operatorname{gram}(\mathrm{g})$ \\
\hline \multicolumn{3}{|c|}{ Mass } \\
\hline pound, avoirdupois (Ib) & 0.4536 & kilogram (kg) \\
\hline
\end{tabular}

\section{SI to Inch/Pound}

\begin{tabular}{|c|c|c|}
\hline Multiply & By & To obtain \\
\hline \multicolumn{3}{|c|}{ Length } \\
\hline centimeter $(\mathrm{cm})$ & 0.3937 & inch (in.) \\
\hline meter (m) & 3.28 & foot (ft) \\
\hline kilometer $(\mathrm{km})$ & 0.6214 & mile (mi) \\
\hline \multicolumn{3}{|c|}{ Area } \\
\hline square kilometer $\left(\mathrm{km}^{2}\right)$ & 0.3861 & square mile $\left(\mathrm{mi}^{2}\right)$ \\
\hline \multicolumn{3}{|c|}{ Volume } \\
\hline liter (L) & 1.057 & quart (qt) \\
\hline \multicolumn{3}{|c|}{ Mass } \\
\hline gram (g) & 0.03527 & ounce, avoirdupois (oz) \\
\hline kilogram (kg) & 2.205 & pound avoirdupois (Ib) \\
\hline \multicolumn{3}{|c|}{ Radioactivity } \\
\hline picocurie per liter (pCi/L) & 0.037 & becquerel per liter (B $/ \mathrm{L}$ ) \\
\hline
\end{tabular}

Temperature in degrees Celsius $\left({ }^{\circ} \mathrm{C}\right)$ may be converted to degrees Fahrenheit $\left({ }^{\circ} \mathrm{F}\right)$ as follows: ${ }^{\circ} \mathrm{F}=\left(1.8 x^{\circ} \mathrm{C}\right)+32$

Temperature in degrees Fahrenheit $\left({ }^{\circ} \mathrm{F}\right)$ may be converted to Celsius $\left({ }^{\circ} \mathrm{C}\right)$ as follows: ${ }^{\circ} \mathrm{C}=\left({ }^{\circ} \mathrm{F}-32\right) / 1.8$

Vertical coordinate information is referenced to the North American Vertical Datum of 1988 (NAVD 88).

Horizontal coordinate information is referenced to the North American Datum of 1983 (NAD 83). Specific conductance is given in microsiemens per centimeter at 25 degrees Celsius $(\mu \mathrm{S} / \mathrm{cm}$ at $\left.25^{\circ} \mathrm{C}\right)$.

Concentrations of chemical constituents in water are given either in milligrams per liter (mg/L) or micrograms per liter $(\mu \mathrm{g} / \mathrm{L})$.

Milligrams per liter is equivalent to parts per million (ppm), and micrograms per liter is equivalent to parts per billion (ppb). 


\section{Abbreviations and Acronyms}






\section{Abbreviations and Acronyms-Continued}

$\mathrm{RL} \quad$ reporting level

RPD relative percent difference

RSD relative standard deviation

RSD5-US risk-specific dose at a risk factor of $10^{-5}$ (USEPA)

SBFFB Santa Barbara fold and fault belt

SD standard deviation

SMCL-CA secondary maximum contaminant level (CDPH)

SMCL-US secondary maximum contaminant level (USEPA)

SRL study reporting level (concentration cutoff for applying the $\leq$ symbol in reporting results)

$\mathrm{ss}_{\mathrm{C}} \quad$ sample-specific critical level

UV ultraviolet

VPDB Vienna Pee Dee Belemnite (the international reference standard for carbon isotopes)

VSMOW Vienna Standard Mean Ocean Water (an isotopic water standard defined in 1968 by the International Atomic Energy Agency)

\section{Selected Terms and Symbols}






\section{Selected Terms and Symbols-Continued}

* value is at a concentration greater than benchmark level

** value is at a concentration greater than upper benchmark level

\section{Organizations}

BOS Branch of Quality Systems (USGS)

CDPH California Department of Public Health

CDPR California Department of Pesticide Regulation

CDWR California Department of Water Resources

LLNL Lawrence Livermore National Laboratory, Livermore, California

NAWQA National Water-Quality Assessment Program (USGS)

NELAP National Environmental Laboratory Accreditation Program

NWQL National Water Quality Laboratory (USGS)

SITL Stable Isotope and Tritium Laboratory, Menlo Park, California (USGS)

SWRCB California State Water Resources Control Board

USEPA U.S. Environmental Protection Agency

USGS U.S. Geological Survey

\section{Selected Chemical Names}

$\begin{array}{ll}\mathrm{CaCO}_{3} & \text { calcium carbonate } \\ \mathrm{CO}_{3}{ }^{2-} & \text { carbonate } \\ \mathrm{CFC} & \text { chlorofluorocarbon } \\ \mathrm{H}_{2} \mathrm{O} & \text { water } \\ \mathrm{HCl} & \text { hydrochloric acid } \\ \mathrm{HCO}_{3}{ }^{-} & \text {bicarbonate } \\ \mathrm{MTBE}^{-} & \text {methyl tert-butyl ether } \\ \mathrm{PCE} & \text { perchloroethene (tetrachloroethene) } \\ \mathrm{PVC} & \text { polyvinyl chloride } \\ \mathrm{SiO} & \text { silicon dioxide } \\ \mathrm{TDS} & \text { total dissolved solids } \\ \mathrm{THM} & \text { trihalomethane } \\ \text { VOC } & \text { volatile organic compound }\end{array}$





\title{
Groundwater-Quality Data in the Santa Barbara Study Unit, 2011: Results from the California GAMA Program
}

\author{
By Tracy A. Davis, Justin T. Kulongoski, and Kenneth Belitz
}

\section{Abstract}

Groundwater quality in the 48-square-mile Santa Barbara study unit was investigated by the U.S. Geological Survey (USGS) from J anuary to February 2011, as part of the California State Water Resources Control Board (SW RCB) Groundwater $A$ mbient $M$ onitoring and $A$ ssessment (GAM A) Program's Priority Basin Project (PBP). The GA M A - PBP was developed in response to the $C$ alifornia Groundwater Quality M onitoring Act of 2001 and is being conducted in collaboration with the SWRCB and $L$ awrence Livermore National Laboratory (LLNL). The Santa Barbara study unit was the thirty-fourth study unit to be sampled as part of the GAMA-PBP.

The GA M A Santa B arbara study was designed to provide a spatially unbiased assessment of untreated-groundwater quality in the primary aquifer system, and to facilitate statistically consistent comparisons of untreated-groundwater quality throughout California. The primary aquifer system is defined as those parts of the aquifers corresponding to the perforation intervals of wells listed in the California Department of Public Health (CDPH) database for the Santa Barbara study unit. Groundwater quality in the primary aquifer system may differ from the quality in the shallower or deeper water-bearing zones; shallow groundwater may be more vulnerable to surficial contamination.

In the Santa B arbara study unit located in Santa B arbara and Ventura Counties, groundwater samples were collected from 24 wells. Eighteen of the wells were selected by using a spatially distributed, randomized grid-based method to provide statistical representation of the study unit (grid wells), and six wells were selected to aid in evaluation of water-quality issues (understanding wells).

The groundwater samples were analyzed for organic constituents (volatile organic compounds [V OCs], pesticides and pesticide degradates, and pharmaceutical compounds); constituents of special interest (perchlorate and $\mathrm{N}$-nitrosodimethylamine [NDM A]); naturally occurring inorganic constituents (trace elements, nutrients, major and minor ions, silica, total dissolved solids [TDS], al kalinity, and arsenic, chromium, and iron species); and radioactive constituents (radon-222 and gross al pha and gross beta radioactivity). Naturally occurring isotopes (stable isotopes of hydrogen and oxygen in water, stables isotopes of inorganic carbon and boron dissolved in water, isotope ratios of dissolved strontium, tritium activities, and carbon-14 abundances) and dissolved noble gases also were measured to help identify the sources and ages of the sampled groundwater. In total, 281 constituents and water-quality indicators were measured.

Three types of quality-control samples (blanks, replicates, and matrix spikes) were collected at up to 12 percent of the wells in the Santa B arbara study unit, and the results for these samples were used to evaluate the quality of the data for the groundwater samples. B lanks rarely contained detectable concentrations of any constituent, suggesting that contamination from sample collection procedures was not a significant source of bias in the data for the groundwater samples. Replicate samples generally were within the limits of acceptable analytical reproducibility. M atrix-spike recoveries were within the acceptable range (70 to 130 percent) for approximately 82 percent of the compounds.

This study did not attempt to evaluate the quality of water delivered to consumers; after withdrawal from the ground, untreated groundwater typically is treated, disinfected, and (or) blended with other waters to maintain water quality. Regulatory benchmarks apply to water that is served to the consumer, not to untreated groundwater. However, to provide some context for the results, concentrations of constituents measured in the untreated groundwater were compared with regulatory and non-regulatory heal th-based benchmarks established by the U.S. Environmental Protection A gency (USEPA) and CDPH and to non-regulatory benchmarks established for aesthetic concerns by CDPH. Comparisons between data collected for this study and benchmarks for drinking water are for illustrative purposes only and are not indicative of compliance or non-compliance with those benchmarks. All organic constituents and most inorganic constituents that were detected in groundwater samples from the 18 grid wells in the Santa B arbara study unit were detected at concentrations less than drinking-water benchmarks. 
Of the 220 organic and special-interest constituents sampled for at the 18 grid wells, 13 were detected in groundwater samples; concentrations of all detected constituents were less than regulatory and non-regulatory health-based benchmarks. In total, V OCs were detected in 61 percent of the 18 grid wells sampled, pesticides and pesticide degradates were detected in 11 percent, and perchlorate was detected in 67 percent. Polar pesticides and their degradates, pharmaceutical compounds, and NDM A were not detected in any of the grid wells sampled in the Santa Barbara study unit.

Eighteen grid wells were sampled for trace elements, major and minor ions, nutrients, and radioactive constituents; most detected concentrations were less than health-based benchmarks. Exceptions are one detection of boron greater than the CDPH notification level (NL-CA) of 1,000 micrograms per liter $(\mu \mathrm{g} / \mathrm{L})$ and one detection of fluoride greater than the CDPH maximum contaminant level (M CL-CA) of 2 milligrams per liter ( $\mathrm{mg} / \mathrm{L}$ ).

Results for constituents with non-regulatory benchmarks set for aesthetic concerns from the grid wells showed that iron concentrations greater than the CDPH secondary maximum contaminant level (SM CL-CA) of $300 \mu \mathrm{g} / \mathrm{L}$ were detected in three grid wells. $M$ anganese concentrations greater than the SM CL-CA of $50 \mu \mathrm{g} / \mathrm{L}$ were detected in seven grid wells. Chloride was detected at a concentration greater than the SM CL-CA recommended benchmark of $250 \mathrm{mg} / \mathrm{L}$ in four grid wells. Sulfate concentrations greater than the SM CL-CA recommended benchmark of $250 \mathrm{mg} / \mathrm{L}$ were measured in eight grid wells, and the concentration in one of these wells was also greater than the SM CL -CA upper benchmark of $500 \mathrm{mg} / \mathrm{L}$. TDS concentrations greater than the SM CL-CA recommended benchmark of $500 \mathrm{mg} / \mathrm{L}$ were measured in $17 \mathrm{grid}$ wells, and concentrations in six of these wells were also greater than the SM CL-CA upper benchmark of $1,000 \mathrm{mg} / \mathrm{L}$.

\section{Introduction}

A bout one-half of the water used for public and domestic drinking-water supply in California is groundwater (K enny and others, 2009). To assess the quality of ambient groundwater in aquifers used for public drinking-water supply and to establish a baseline groundwater-qual ity monitoring program, the California State Water R esources Control B oard (SWRCB), in cooperation with the U.S. Geological Survey (USGS) and L awrence Livermore $N$ ational Laboratory ( $L L N L$ ), implemented the Groundwater A mbient M onitoring and A ssessment (GAM A) Program (California Environmental Protection A gency, 2011, website at http://www.waterboards. ca.gov/water_issues/programs/gama/). The main goals of the GA M A Program are to improve groundwater monitoring and to increase the availability of groundwater-quality data to the public. The GA M A Program currently consists of four projects: (1) the GA M A Priority Basin Project (PBP) conducted by the USGS (U.S. Geological Survey, 2011a, California Water Science Center w ebsite at http://ca.water. usgs.gov/gama/); (2) the GAM A Domestic Well Project (DWP) conducted by the SWRCB; (3) the GA M A Special Studies conducted by LLNL; and (4) the GeoTracker GAM A online database conducted by the SWRCB. The GAM A PBP primarily focuses on the deep part of the groundwater resource, which is typically used for public drinking-water supply. The GA M A DWP generally focuses on the shallow aquifer systems, which may be particularly at risk as a result of surficial contamination. The GAMA Special Studies Project focuses on using research methods to help explain the source, fate, transport, and occurrence of chemicals that can affect groundwater quality. GeoTracker GA M A is an online interface serving all published and quality-assurance/ quality-control (QA/QC) approved analytical data from the GA M A Program (California State Water Resources Control B oard, 2009, website at http://geotracker.waterboards.ca.gov/ gama/). GeoTracker GA M A also stores groundwater-quality data and related reports collected by other State agencies, such as the California Department of Public Health (CDPH), California Department of Water Resources (CDWR), California D epartment of Pesticide Regulation (CDPR), and data collected by the SWRCB and Regional Boards from groundwater monitoring wells at contaminated or remediated sites.

The GA M A Program was initiated by the SW RCB in 2000 and later expanded by the Groundwater Quality M onitoring A ct of 2001 (State of California, 2001a, 2001b, Sections 10780-10782.3 of the California Water Code, A ssembly Bill 599). The GA M A -PB P assesses groundwater quality in key groundwater basins that account for more than 90 percent of all groundwater used for public supply in the State. For the GAM A - PBP, the USGS, in collaboration with the SWRCB, developed the monitoring plan to assess groundwater basins through direct and other statistically reliable sample approaches (B elitz and others, 2003; California State Water Resources Control B oard, 2003). A dditional partners in the GAMA-PBP include LL NL, CDPH, CDWR, CDPR, local water agencies, and well owners (K ulongoski and Belitz, 2004). Participation in the project is entirely voluntary.

The range of hydrologic, geologic, and climatic conditions in California should be considered in an assessment of groundwater quality. B elitz and others (2003) partitioned the State into 10 hydrogeologic provinces, each with distinctive hydrologic, geologic, and climatic characteristics: Cascades and M odoc Plateau, K lamath M ountains, N orthern Coast Ranges, Central Valley, Sierra N evada, B asin and Range, Southern Coast Ranges, Transverse Ranges and selected Peninsular Ranges, Desert, and San Diego Drainages (fig. 1). These 10 hydrogeologic provinces include groundwater basins and subbasins designated by the CDW R (California Department of Water Resources, 2003). Groundwater basins and subbasins generally consist of relatively permeable, unconsolidated deposits of alluvial or 
volcanic origin. Eighty percent of California's approximately 16,000 active and standby drinking-water wells listed in the statewide database maintained by the CDPH (hereinafter referred to as CDPH wells) are located in groundwater basins and subbasins within the 10 hydrogeologic provinces. $G$ roundwater basins and subbasins were prioritized for sampling on the basis of the number of CDPH wells in the basin, with secondary consideration given to municipal groundwater use, agricultural pumping, the number of formerly leaking underground fuel tanks, and the number of registered pesticide applications (B elitz and others, 2003). Of the 472 basins and subbasins designated by the CDW R, 116 were identified as priority basins that include approximately 95 percent of the CDPH wells in California. In addition, some areas outside of the defined groundwater basins were included to achieve representation of the 20 percent of the CDPH wells

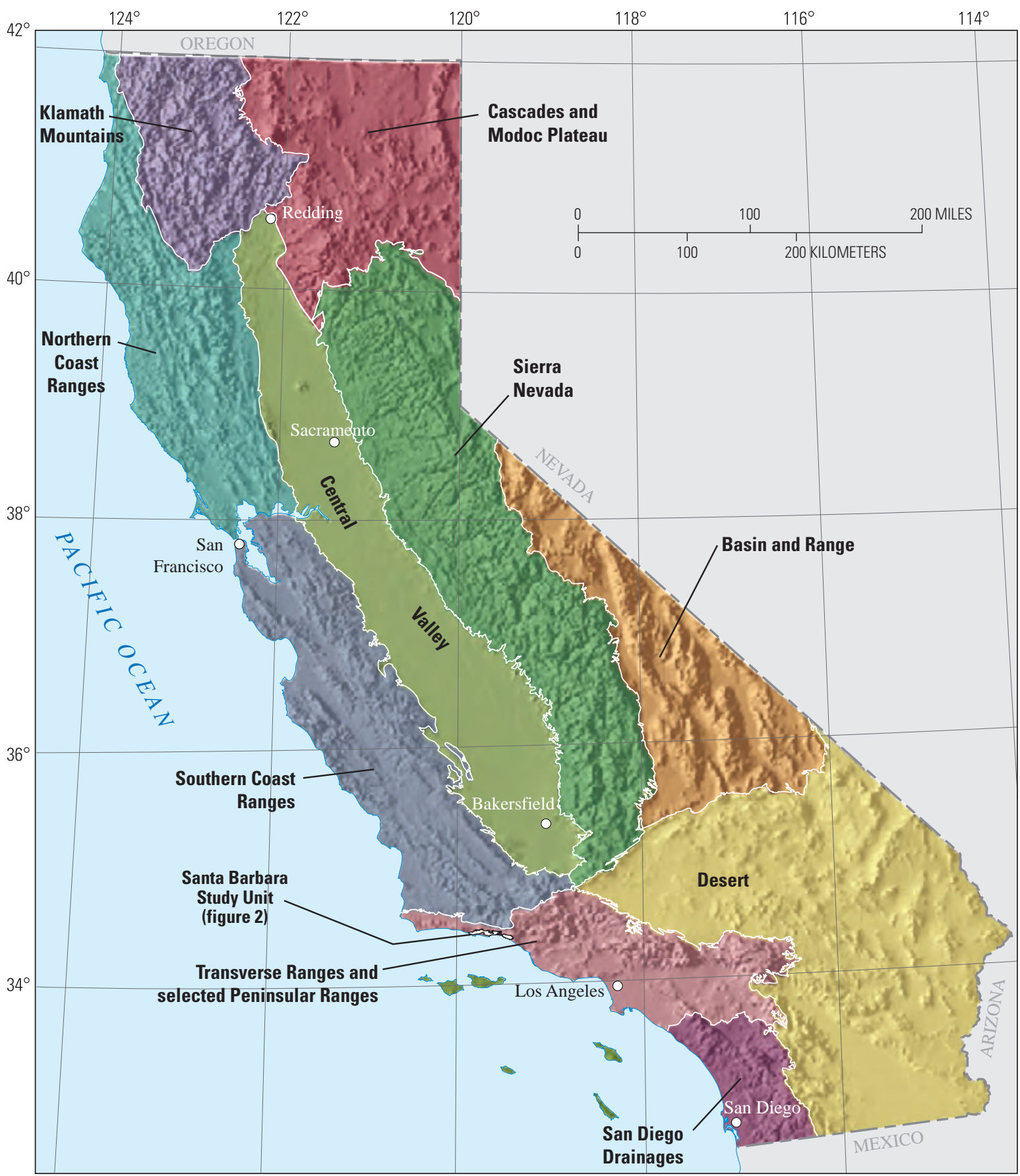

Shaded relief derived from U.S. Geological Survey

Provinces from Belitz and others, 2003

National Elevation Dataset, 2006,

Albers Equal Area Conic Projection

Figure 1. Hydrogeologic provinces of California and the location of the Santa Barbara study unit, California GAMA Priority Basin Project. 
not located in the groundwater basins. The priority basins, selected other basins, and selected areas outside of basins were grouped into 35 study units for sampling. The Santa Barbara study unit is composed of five groundwater subbasins in the Transverse Ranges and selected Peninsular Ranges hydrogeologic province (fig. 1).

Three types of water-quality assessments are being conducted with the data collected in each study unit: (1) Status- assessment of the current quality of the groundwater resource; (2) Understanding-identification of the natural and human factors affecting groundw ater quality; and (3) Trends - detection of changes in groundwater quality over time (Kulongoski and B elitz, 2004). The assessments are intended to characterize the quality of groundwater in the primary aquifer system of the study units, not the treated drinking water delivered to consumers by water purveyors. The primary aquifer system is defined as parts of the aquifers corresponding to the perforation intervals of wells listed in the CDPH databases for the study units. The CDPH database lists wells used for public drinking-water supplies and includes wells from systems classified as community (such as those in cities, towns, and mobile-home parks), non-transient and non-community (such as those in schools, workplaces, and restaurants), and transient and non-community (such as those in campgrounds and parks). Collectively, the CDPH refers to these wells as "public-supply" wells. Groundwater quality in the primary aquifer system may differ from the quality in the shallow or deep parts of the aquifer systems. In particular, shallow groundwater may be more vul nerable to surface contamination. As a result, samples from shallow wells (such as many private domestic wells and environmental monitoring wells) can have higher concentrations of constituents (such as volatile organic compounds [V OCs] and nitrate) from anthropogenic sources than samples from wells screened in the underlying primary aquifer system ( $L$ andon and others, 2010).

The GAM A -PB P is unique in California because it includes many chemical analyses that are not otherwise available in statewide water-quality monitoring datasets. Groundwater samples collected for the GA M A-PBP are typically analyzed for approximately 300 chemical constituents by using methods with lower detection limits than required by the $\mathrm{CDPH}$ for regulatory monitoring of drinking-water wells. These analyses will be especially useful for providing an early indication of changes in groundwater quality. In addition, the GA M A-PBP analyzes samples for a suite of constituents more extensive than that required by $\mathrm{CDPH}$ and for a suite of chemical and isotope tracers for exploring hydrologic and geochemical processes. A broader understanding of groundwater composition is useful for identifying the natural and human factors affecting water quality. U nderstanding the occurrence and distribution of chemical constituents of significance to water quality is important for the long-term management and protection of groundwater resources.

This USGS Data Series Report is similar to other USGS Data Series Reports written for the GA M A -PBP study units sampled to date and is the first in a series of reports (i.e., Data Series Report, Scientific Investigations Report, and Fact Sheet) presenting the water-quality data collected in the Santa B arbara study unit. Data Series Reports and additional reports addressing the status, understanding, and trends aspects of the water-quality assessments of each study unit are available from the U.S. Geological Survey (2011b) at http://ca.water. usgs.gov/gama/includes/GA M A_publications.html.

\section{Purpose and Scope}

The purposes of this report are to describe (1) the hydrogeologic setting of the Santa B arbara study unit, the study design, and the study methods; (2) the analytical results for groundwater samples collected in the Santa B arbara study unit, and (3) the results of quality-control (QC) analyses. Groundwater samples were analyzed for field water-quality indicators; organic, special-interest, inorganic, and radioactive constituents; naturally occurring isotopes; and dissolved gases. The chemical data presented in this report were evaluated by comparison to State and Federal drinking-water regulatory and other non-regulatory standards that are applied to treated drinking water. Regulatory and non-regulatory benchmarks considered for this report are those established by the U.S. Environmental Protection A gency (USEPA) and the $\mathrm{CDPH}$. Discussion of the factors that influence the distribution and occurrence of the constituents detected in groundwater samples will be the subject of subsequent publications.

\section{Hydrogeologic Setting}

The Santa B arbara study unit lies within the Transverse Ranges and selected Peninsular Ranges hydrogeologic province described by B elitz and others (2003). The study area covers 48 square miles $\left(\mathrm{mi}^{2}\right)$, primarily in Santa Barbara County, and extends into Ventura County to the east. The Santa Barbara study unit is a narrow coastal strip flanked by the Santa Y nez M ountains in the north with summit el evations over 4,000 feet (ft) and bounded by the Pacific Ocean in the south. The study unit includes five CDWR-defined groundwater basins and sub-basins: (from west to east) Goleta, Foothill, Santa Barbara, M ontecito, and Carpinteria (California Department of Water Resources, 2003) (fig. 2A). 

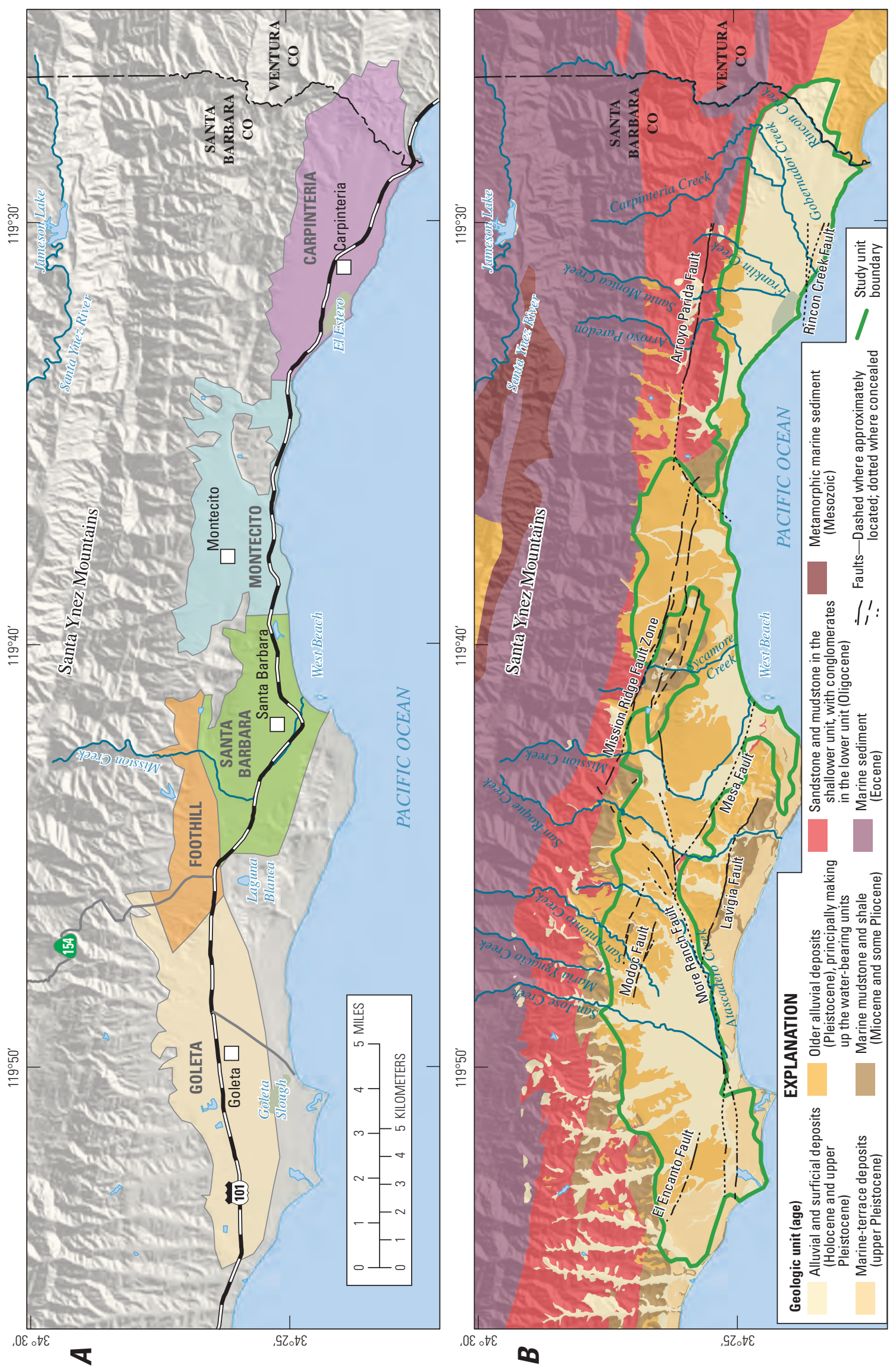

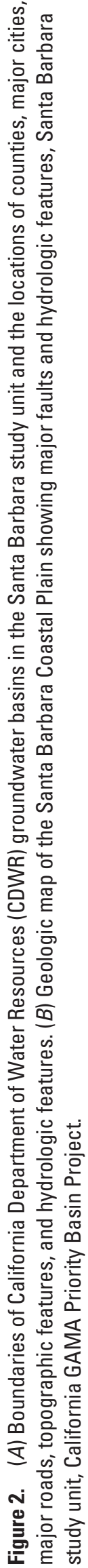


The Santa B arbara fold and fault belt (SBFFB) and the overlapping Santa Y nez M ountains uplift dominate the structural geology of the Santa B arbara coastal plain. The eastwest trending SBFFB is defined by three major fault systems: the west-northwest-trending M ission Ridge fault zone and A rroyo Parida fault, and the east-northeast-trending $M$ ore Ranch fault (fig. 2B) (M inor and others, 2009). These systems and other individual faults define some subbasin boundaries as they impede water flow within and along the perimeter of the Santa B arbara study unit. A long the southern boundary of the study unit, seawater intrusion is partially restricted by uplift along the M ore Ranch fault in the southwest, M esa and $L$ avigia faults in the central part of the coastal plain, and Rincon Creek fault in the southeast (California Department of Water Resources, 2004a-e).

Deformed Eocene marine sediments al ong the southern flank of the Santa Ynez Mountains form the backdrop to the Santa B arbara coastal plain and give way to Oligocene through Pleistocene sedimentary rocks of the lower foothills (fig. 2B). M oderately warped Pleistocene marine and terrestrial sediments underlie many of the hills and mesas, with much of the low-lying, urbanized area underlain by Pleistocene and Holocene surficial deposits (Minor and others, 2009). The Santa B arbara study unit boundary encompasses water-bearing formations which are made up of these Quaternary deposits.

The principal aquifer formations of the Santa B arbara study unit are the older alluvial deposits and the underlying Santa B arbara and Casitas Formations. L ocated in the western part of the Santa B arbara coastal plain, the middle and lower Pleistocene Santa Barbara Formation consists of fine- to medium-grained marine sandstone. In the central region of the study unit, the oldest alluvial deposits interstratify the Santa B arbara Formation below and may be correlative with the Casitas Formation. The consolidated nonmarine deposits of the Casitas Formation are of upper and middle Pleistocene age. The thickness varies from less than $164 \mathrm{ft}$ found in outcrops to much thicker in the subsurface of Carpinteria, M ontecito, and possibly Santa B arbara cities. The Casitas Formation is overlain with marine terrace deposits and was previously mapped as the Carpinteria Formation by Lian (1954). Alluvial deposits typically present in the upper part of marine terrace sequences may also be correlative with the intermediate and older alluvial deposits ( $M$ inor and others, 2009).

The sources of surface discharge for the study unit are several creeks flowing from the mountains out to the Pacific $O$ cean. The study unit is primarily drained by M ission Creek and its tributaries (fig. 2B). The creek originates in the Santa Ynez Mountains and flows southeasterly to where it enters the Pacific Ocean just east of West Beach (Izbicki and others, 2009). Other surface-drainage features are San J ose, M aria Y gnacio, San A ntonio, A tascadero, San Roque, Sycamore, A rroyo Paredon, Santa M onica, Rincon, Carpinteria, and Gobernador Creeks. Sources of recharge in the groundwater basins are infiltration of precipitation and irrigation waters, seepage from creeks and streams, imported water from L ake Cachuma and Gibraltar Reservoir, and subsurface inflow (California Department of Water Resources, 2004a-e).

The climate in the Santa B arbara study unit is characterized as $M$ editerranean, with warm, dry summers and cool, wet winters. The National Climatic Data Center located at the Santa B arbara M unicipal A irport reported an average annual temperature of 58 degrees Fahrenheit $\left({ }^{\circ} \mathrm{F}\right)$ (14.5 degrees Celsius [ ${ }^{\circ} \mathrm{C}$ ]) for 2010 ; total annual precipitation was higher than normal (about 17 inches) at more than 27 inches, occurring as rain during the winter and early spring (U.S. D epartment of Commerce, National Oceanic and A tmospheric A dministration, 2010).

\section{Methods}

M ethods used for the GA M A - PB P were selected to achieve the following objectives: (1) design a sampling plan for suitable statistical representation; (2) collect samples in a consistent manner; (3) analyze samples by using proven and reliable laboratory methods; (4) assure the quality of the groundwater data; and (5) maintain data securely and with relevant documentation. The appendix contains detailed descriptions of the sample-collection protocols and analytical methods, the quality-assurance (QA) methods, and the results of analyses of QC samples.

\section{Study Design}

The wells selected for sampling in this study reflect the combination of two well-selection strategies. Eighteen wells were selected to provide a statistically unbiased, spatially distributed assessment of the quality of groundwater resources used for public drinking-water supply. Hereinafter, wells sampled as part of the spatially distributed, randomized grid-cell network are referred to as "grid wells." Six additional, non-randomized wells (hereinafter referred to as "understanding wells") were selected to aid in the understanding of specific issues associated with vertical changes in groundwater quality and age in different parts of the Santa B arbara study unit.

The grid wells were selected using a randomized gridbased method (Scott, 1990). The randomized grid-based method divides the study unit into equal-area grid cells; however, geographic features may force a grid cell to be divided into multiple pieces to obtain the designated coverage area for each cell. For instance, a part of a grid cell may be located on either side of a mountain range, but the grid cell is still considered one grid cell. The Santa B arbara study unit was divided into 20 equal-area grid cells, each approximately $2.4 \mathrm{mi}^{2}$ in area. 
The objective was to sample one CDPH well in each grid cell (fig. 3A). If a grid cell contained more than one CDPH well, each well randomly was assigned a rank. The highest ranking well that met basic sampling criteria (for example, sampling point located prior to treatment or capability to pump for several hours) was sampled. If a grid cell contained no accessible CDPH wells, then other types of wells, such as irrigation wells, domestic wells, or commercial wells, were considered for sampling. These "alternative" wells were identified from wells listed in USGS databases or by doorto-door canvassing. Wells with depths and screened intervals similar to those in CDPH wells in the area were selected. For the six cells that contained no active wells, wells in adjacent cells near the cell boundaries were considered for sampling. In this fashion, 1 well was selected for sampling in 18 of the 20 grid cells to provide a spatially distributed, randomized monitoring netw ork. The remaining two cells contained no accessible wells.

The 18 grid wells sampled in the Santa Barbara study unit were named by using the prefix "SB" and by using a suffix numbered by location within the study unit, from west to east (fig. 3B). The six understanding wells sampled as part of the study were not included in the statistical characterization of water quality in the Santa B arbara study unit because inclusion of these wells would have lead to the overrepresentation of some cells. These additional wells were named by using the prefix "SBU" ("U" indicating "understanding") and by using a suffix numbered from west to east within the study unit. Of the understanding wells, four were short-screened monitoring (observation) wells at a single location with openings at different depths in the aquifer system.

The GAMA alphanumeric identification number for each well, along with the date sampled, well altitude, well type, and available well-construction information are show $n$ in table 1. Groundwater samples were collected during J anuary and February 2011. Grid wells included 11 CDPH wells, 5 irrigation wells, and 2 domestic wells. Understanding wells included four monitoring (observation) wells, one publicsupply well, and one unused well.

Well locations were verified by using a global positioning system (GPS), 1:24,000-scale U SGS topographic maps, comparison with existing well information in USGS and CDPH databases, and information provided by well owners, drillers' logs, or other sources of construction information. Well locations and information were recorded by hand on field sheets and electronically on field laptop computers using the A lternate Place Entry (APE) program designed by the USGS. All information was verified and then uploaded into the USGS National Water Information System (N W IS). Well owner, well use, and well location information is confidential.

\section{Sample Collection and Analysis}

Samples were collected in accordance with the protocols established by the USGS National Water-Qual ity A ssessment (NAW QA ) Program (K oterba and others, 1995) and the USGS National Field M anual (NFM) (U.S. Geological Survey, variously dated). These sampling protocols were followed so that representative samples of groundwater were collected at each site and so that the samples were collected and handled in ways that minimized the potential for contamination.

All 24 wells in the Santa B arbara study unit were sampled for a standard set of constituents (table 2 ). Tables 3A-K list the compounds analyzed in each constituent class. Groundwater samples were analyzed for $85 \mathrm{~V} \mathrm{OCs} \mathrm{(table} 3 \mathrm{~A}$ ); 63 pesticides and pesticide degradates (table 3B ); 60 polar pesticides and degradates (table 3C); 13 pharmaceutical compounds (table 3D); 2 constituents of special interest (table 3E); 24 trace elements (table 3F); 5 nutrients (table 3G); 9 major and minor ions, silica, and total dissolved solids (table $3 \mathrm{H}$ ); arsenic, chromium, and iron species (table 31); stable isotopes of hydrogen and oxygen in water, dissolved inorganic carbon, and dissolved boron, and isotope ratios of dissolved strontium, and 5 radioactive constituents, including tritium and carbon-14 abundance (table 3J); stable isotope ratios of helium, 5 dissolved noble gases, and tritium (table 3K). The methods used for sample collection and analysis are described in the appendix section titled "Sample Collection and A nalysis."

\section{Data Reporting}

The methods and conventions used for reporting the data are described in the appendix section titled "Data Reporting." Six constituents analyzed in this study were measured by more than one method at the USGS N ational Water Q uality L aboratory (NW QL), four of which only have results reported from the preferred method (see the appendix section titled "Constituents on M ultiple A nalytical Schedules" for the preferred method selection procedure). Three field waterquality indicators - alkalinity, $\mathrm{pH}$, and specific conductance (table 4) - were measured in the field and at the NWQL, and three other constituents - total arsenic, chromium, and iron-were measured by two different laboratories; both sets of results are reported for each of these constituents. Tritium activities were measured by two different laboratories, but only one set of results was available at the time this report was published. 

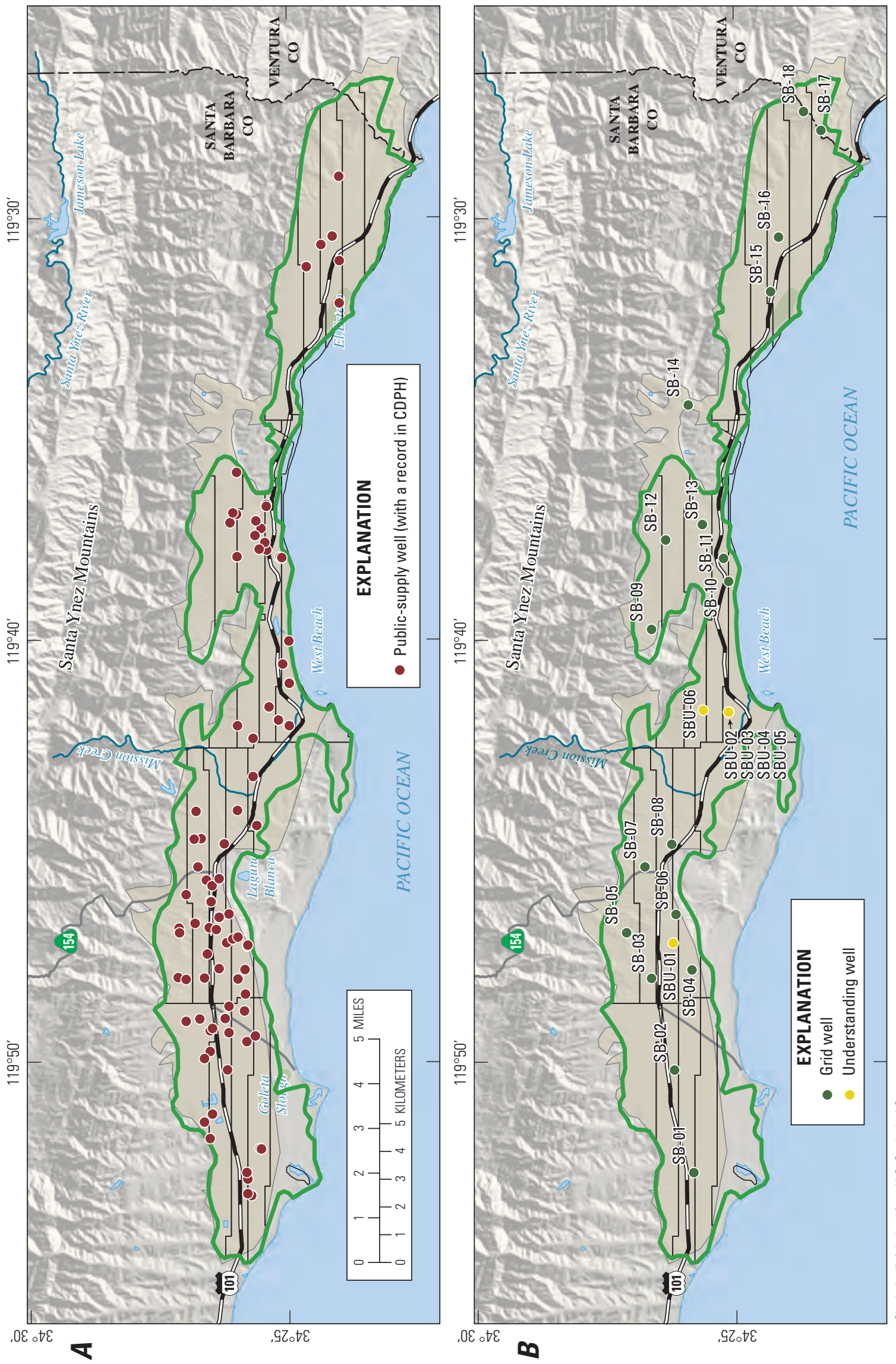

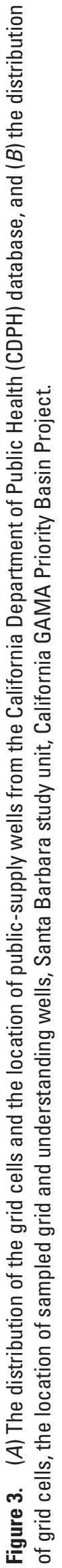




\section{Quality-Assurance Methods}

The QA procedures used for this study followed the protocols used by the NAW QA Program (K oterba and others, 1995) and described in the NFM (U.S. Geological Survey, variously dated). The QA plan followed by the NW Q L, the primary laboratory used to analyze samples for this study, is described in Pirkey and Glodt (1998) and M aloney (2005). QC samples collected in the Santa B arbara study unit are blanks, replicates, and matrix and surrogate spikes. QC samples were collected to evaluate potential contamination, as well as bias and variability of the data that may have resulted from sample collection, processing, storage, transportation, and laboratory analysis. QA procedures and $Q C$ results are described in the appendix section titled "Quality-A ssurance M ethods and Results."

\section{Water-Quality Results}

\section{Quality-Control Results}

Results of QC analyses (blanks, replicates, and matrix and surrogate spikes) were used to eval uate the quality of the data for the groundwater samples. On the basis of detections in field blanks collected for this and previous GAMAPB P study units, raised "study reporting levels" (SRLs) for 1 volatile organic compound (1,2,4-trimethylbenzene), 11 trace elements, and 1 nutrient (ammonia) were applied (see table $\mathrm{A} 3$ and additional discussion in the appendix section titled "D etections in Field B lanks and A pplication of SRLs"). Detections of these 13 constituents with concentrations less than their SRLs were flagged with a less than or equal to symbol $(\leq)$ in this report and in the NWIS database (tables 5, 8 , and 9 ).

Results from the replicate analyses confirm that the procedures used to collect and analyze the samples were consistent. Variability for nearly 100 percent of the replicate pairs for constituents detected in samples was within the acceptable limits (tables A 4A-C). The criteria for acceptable replication is described in the appendix section titled "Quality A ssurance M ethods and Results." M edian matrix-spike recoveries for 31 of the 205 organic constituents analyzed were lower than the acceptable limit of 70 percent, and 6 were greater than the acceptable limit of 130 percent (tables 3A-D and $A 5 A-D)$. The constituents for which low recoveries occurred might not have been detected in some samples if they were present in the samples at concentrations near the laboratory reporting levels (LRLs). Constituents with high recoveries may indicate that reported values could be greater than what is in the sample. The $Q C$ results are described in the appendix section titled "Q uality-C ontrol M ethods and Results."

\section{Comparative Benchmarks}

Concentrations of constituents detected in groundwater samples were compared with CDPH and U SEPA regulatory and non-regulatory drinking-water health-based benchmarks and benchmarks established for aesthetic purposes (California Department of Public Health, 2008a, b; U.S. Environmental Protection Agency, 2008a-c). The chemical data presented in this report are meant to characterize the quality of the untreated groundwater within the primary aquifer system of the Santa B arbara study unit and are not intended to represent the treated drinking water delivered to consumers by water purveyors. The chemical composition of treated drinking water may differ from untreated groundwater because treated drinking water may be subjected to disinfection, filtration, mixing with other waters, and (or) exposure to the atmosphere prior to its delivery to consumers. Comparisons of untreated groundwater to benchmarks are for illustrative purposes only and are not indicative of compliance or non-compliance with drinking-water regulations. The following benchmarks were used for comparisons:

- MCL - M aximum C ontaminant L evel. Legally enforceable standards that apply to public-water systems and are designed to protect public heal th by limiting the levels of contaminants in drinking water. MCL s established by the USEPA are the minimum standards with which States are required to comply, and individual States may choose to set more stringent standards. CDPH has established M CL s for additional constituents not regulated by the USEPA, as well as lowered the benchmark concentrations for a number of constituents with M CL s established by the USEPA. In this report, a benchmark set by the USEPA and adopted by CDPH is labeled "M CL-US," and one set by $C D P H$ that is more stringent than the MCL-US is labeled "MCL-CA." Well owners are notified when constituents are detected at concentrations greater than an M CL-US or an M CL-CA benchmark in samples collected for the GAM A - PBP, but these detections do not constitute violations of $C D P H$ regulations.

- AL -Action L evel. L egally enforceable standards that apply to public-water systems and are designed to protect public health by limiting the levels of copper and lead in drinking water. Detections of copper or lead greater than the action-level benchmarks trigger requirements for mandatory water treatment to reduce the corrosiveness of water to water pipes. The action levels established by the USEPA and CDPH are the same; thus, these benchmarks are label ed "A L-US" in this report. 
- SM CL - Secondary Maximum Contaminant Level. N on-enforceable standards applied to constituents that affect the aesthetic qualities of drinking water, such as taste, odor, and color, or the technical qualities of drinking water, such as scaling and staining. Both the USEPA and CDPH define SMCLs, but unlike MCLs, SM CLs established by CDPH are not required to be at least as stringent as those established by USEPA. SM CL s established by CDPH are used in this report (SM CL-CA) for all constituents that have SM CL-CA values. The SM CL-US is used for $\mathrm{pH}$ because no SMCL-CA has been defined.

- NL-Notification Level. Health-based notification levels established by CDPH for some of the constituents in drinking water that lack M CLs (NL CA ). If a constituent is detected in drinking water at concentrations greater than its N L-CA, California State law requires timely notification of local governing bodies and recommends consumer notification.

- HAL - L ifetime Health A dvisory L evel. The maximum concentration of a constituent at which its presence in drinking water is not expected to cause any adverse carcinogenic effects for a lifetime of exposure. HALS are established by the USEPA (HAL-US) and are calculated assuming consumption of 2 liters (2.1 quarts) of water per day over a 70-year lifetime by a 70-kilogram (154-pound) adult and that 20 percent of a person's exposure comes from drinking water.

- RSD5-Risk-Specific Dose. The concentration of a constituent in drinking water corresponding to an excess estimated lifetime cancer risk of 1 in 100,000 . RSD5 is an acronym for risk-specific dose at the $10^{-5}$ risk level $\left(10^{-5}\right.$ equals $\left.1 / 100,000\right)$. RSD 5s are calculated by dividing the $10^{-4}$ cancer risk concentration established by the USEPA by 10 (RSD5-US).

For constituents with regulatory benchmarks (M CLs or $A L s)$, detections in groundwater samples were compared to the M CL-US, M CL-CA, or A L-US. Constituents with SM CLS were compared with the SM CL-CA. For chloride, sulfate, specific conductance, and total dissolved solids, $\mathrm{CDPH}$ defines a "recommended" and an "upper" SM CL-CA; detections of these constituents in groundwater samples were compared with both levels. The SM CL -US levels for these constituents correspond to their recommended SM CL-CA s. Detected concentrations of constituents without an $M C L, A L$, or $S M C L$ were compared to the N L-CA. For constituents without an $M C L, A L, S M C L$, or NL-CA, detected concentrations were compared with the HAL-US. For constituents without an $M C L, A L, S M C L, N L-C A$, or HAL-US, detected concentrations were compared with the RSD5-US. Note that using this hierarchy to select the comparative benchmark for a constituent with more than one type of established benchmark will not necessarily result in selection of the benchmark with the lowest concentration. For example, for zinc the SM CL-CA is 5,000 micrograms per liter $(\mu \mathrm{g} / \mathrm{L})$ and the HAL-US is $2,000 \mu \mathrm{g} / \mathrm{L}$, but the comparative benchmark selected by this hierarchy is the SM CL-CA. The comparative benchmarks used in this report are listed in tables $3 \mathrm{~A}-\mathrm{K}$ for all constituents and in tables 4-13 for constituents detected in groundwater samples from the Santa B arbara study unit. Established benchmarks are not available for all constituents analyzed for this study. Detections of constituents at concentrations greater than the selected comparative benchmarks are marked with an asterisk $(*)$ in tables $4,8,10$, and 11.

\section{Groundwater-Quality Data}

Results from analyses of untreated groundwater samples from the Santa B arbara study unit are presented in tables 4-13. Groundwater samples collected in the Santa B arbara study unit were analyzed for 281 constituents. Of those constituents, 207 were not detected in any of the samples, and 66 constituents were detected. The results for stable isotopes of dissolved boron, isotope ratios of dissolved strontium, and the LLNL results for dissolved noble gases, tritium, and helium isotope ratios have not been received and are not presented in this report; they will be included in a subsequent publication.

For organic and special-interest constituents, the results tables include only those constituents that were detected, and the following summary statistics are presented for all of the grid wells: the number of wells at which each analyte was detected, the frequency at which it was detected (in relation to the number of grid wells in the study unit), and the total number of constituents detected at each well (except for special-interest constituents because only one constituent was analyzed). For the inorganic, isotopic, and radioactive constituents, the tables include all of the constituents and wells that were analyzed.

Water-quality indicators measured in the field and at the NW Q L are included in table 4. The results of groundwater analyses, organized by constituent class, are presented in tables 5-13:

- Organic constituents

- Volatile organic compounds (table 5)

- Pesticides and pesticide degradates (table 6)

- Perchlorate (table 7)

- Inorganic constituents

- Trace elements (table 8)

- Nutrients (table 9)

- M ajor and minor ions, silica, and total dissolved solids (table 10)

- A rsenic, chromium, and iron species (table 11) 
- Isotope tracers (table 12)

- Radioactive constituents

- Radon-222 (table 13A)

- Gross alpha and gross beta radioactivity (table 13B)

\section{Water-Quality Indicators}

Field measurements of dissolved oxygen and water temperature and field and laboratory measurements of $\mathrm{pH}$, specific conductance, and alkalinity are presented in table 4. Bicarbonate and carbonate concentrations were calculated from the pH and alkalinity results. Dissolved oxygen and alkalinity are used as indicators of natural processes that affect water chemistry. The pH value indicates the acidity or basicity of the water. Specific conductance is the measure of electrical conductivity of the water and is proportional to the amount of total dissolved solids (TDS) in the water.

Field $\mathrm{pH}$ values were outside of the SM CL -US range for 17 percent of the Santa Barbara study unit grid wells: three well samples had field $\mathrm{pH}$ values less than 6.5 (table 4). L ow $\mathrm{pH}$ in water may contribute to corrosion of pipes, and high $\mathrm{pH}$ in water may contribute to scaling. Laboratory $\mathrm{pH}$ values may differ from field $\mathrm{pH}$ values because the $\mathrm{pH}$ of groundwater may change upon removal from the ambient environment and exposure to the atmosphere.

Field specific-conductance values were greater than the recommended SM CL-CA of 900 microsiemens per centimeter at 25 degrees Celsius $\left(\mu \mathrm{S} / \mathrm{cm}\right.$ at $\left.25^{\circ} \mathrm{C}\right)$ for 15 of the 18 gridwell samples, 5 of which were also greater than the upper benchmark of $1,600 \mu \mathrm{S} / \mathrm{cm}$ at $25^{\circ} \mathrm{C}$. Five Santa Barbara understanding-well samples had field specific-conductance values that were greater than the recommended SM CL-CA, one of which was also greater than the upper SM CL-CA (table 4).

\section{Organic Constituents}

VOCs are present in paints, solvents, fuels, fuel additives, refrigerants, fumigants, and disinfected water, and are characterized by their tendency to evaporate. V OCs generally persist longer in groundwater than in surface water because groundwater is isolated from the atmosphere.

Of the $85 \mathrm{~V} \mathrm{OCs}$ analyzed for the Santa B arbara study unit, 11 were detected in groundwater samples; 9 of these $11 \mathrm{VOC}$ s were detected in grid wells. All concentrations were less than health-based benchmarks (table 5). One or more V OCs were detected in 11 of the 18 grid-well samples (about 61 percent detection frequency). The trihal omethane chloroform was the most frequently detected $\mathrm{VOC}$ in the study unit. Chloroform is among the most commonly detected V OCs in groundwater nationally, and its source is attributed, in part, to the recycling of chlorinated waters to aquifers (Zogorski and others, 2006). Five other V OCs also had detection frequencies greater than 10 percent in the grid wells: bromodichloromethane; 1,1,1-trichloroethane; 1,1-dichloroethane; perchloroethene (PCE, tetrachloroethene); and the gasoline oxygenate, methyl tert-butyl ether (M TBE). Four V OCs were detected in one of the understanding-well samples in the Santa B arbara study unit (SBU-05).

Pesticides include herbicides, insecticides, and fungicides and are used to control weeds, insects, fungi, and other pests in agricultural, urban, and suburban settings. Of the 120 pesticides and pesticide degradates analyzed at 18 grid wells in the Santa B arbara study unit, one was detected in groundwater samples: simazine. All concentrations were less than heal th-based benchmarks (table 6 ). N o pesticide or pesticide degradate was detected in any of the six understanding wells.

Pharmaceutical compounds may enter the environment in many ways, including septic systems, discharge of treated wastewater, sewer lines, seepage from landfills, land application of manure fertilizers, and runoff from animal wastes (Fram and B elitz, 2011). Pharmaceutical compounds were not detected at concentrations greater than or equal to the method detection limits (M DLs) in any of the 24 wells sampled for the Santa B arbara study unit.

\section{Constituents of Special Interest}

Perchlorate and NDM A are constituents of special interest in California because they may adversely affect water quality and recently have been detected in water supplies (California Department of Public Health, 2008b). Perchlorate was detected in 12 of 18 grid-well samples (about 67 percent detection frequency) and in 2 of the understandingwell samples (table 7). Perchlorate was not detected at concentrations greater than the M CL -CA of $6 \mu \mathrm{g} / \mathrm{L}$ in any of the grid- or understanding-well samples in the Santa B arbara study unit. NDMA was not detected in any of the grid or understanding wells and therefore was not included in table 7.

\section{Inorganic Constituents}

Unlike the organic constituents and the constituents of special interest, most of the inorganic constituents generally are naturally present in groundwater, al though their concentrations may be influenced by human activities.

Seventeen of the 24 trace el ements and 1 of the major and minor ions analyzed and detected in the Santa B arbara study unit have regulatory or non-regulatory health-based benchmarks (tables $3 \mathrm{~F}, 3 \mathrm{H}$ ). Of these 18 constituents with health-based benchmarks, 4 constituents were detected at concentrations greater than benchmarks; all detections of 14 constituents had concentrations less than their respective benchmarks. One grid-well sample (SB -14) contained boron and fluoride at concentrations greater than benchmark levels: CDPH notification level (NL-CA) of $1,000 \mu \mathrm{g} / \mathrm{L}$ and MCL-CA 
of 2 milligrams per liter (mg/L), respectively (tables 8 and 10). One understanding-well sample had detections of barium, boron, and strontium greater than the benchmark levels:

$\mathrm{MCL}-\mathrm{CA}$ of $1,000 \mu \mathrm{g} / \mathrm{L}, \mathrm{NL}-\mathrm{CA}$ of $1,000 \mu \mathrm{g} / \mathrm{L}$, and HAL-US of $4,000 \mu \mathrm{g} / \mathrm{L}$, respectively.

Nutrients (nitrogen and phosphorus) present in groundwater can affect biological activity in aquifers and in surface-water bodies that receive groundwater discharge. Inorganic nitrogen may be present in the form of ammonia, nitrite, or nitrate, depending on the oxidation-reduction state of the groundwater. High concentrations of nitrate can adversely affect human health, particularly the health of infants. All concentrations of ammonia, nitrite, and nitrate measured in the 24 Santa B arbara study unit wells were less than health-based benchmarks (table 9 ).

The levels of certain trace el ements, major-ion composition, and TDS content in groundwater affect the aesthetic properties of water, such as taste, color, and odor, and the technical properties of water, such as scaling and staining. A lthough there are no adverse heal th effects directly associated with these properties, they may reduce consumer satisfaction with the water or may have economic effects. The CDPH has established non-enforceable benchmarks (SM CL-CAs) that are based on aesthetic properties rather than on human-health concerns for iron, manganese, silver, zinc, chloride, sulfate, and TDS. Iron and manganese are trace elements whose concentrations are affected by the oxidationreduction state of the groundwater. Precipitation of minerals containing iron or manganese may cause orange, brown, or black staining of surfaces.

Iron concentrations greater than the SM CL-CA of $300 \mu \mathrm{g} / \mathrm{L}$ were detected in three grid-well samples. Manganese concentrations greater than the SMCL-CA of $50 \mu \mathrm{g} / \mathrm{L}$ were detected in seven grid-well samples. I ron was detected at a concentration greater than the benchmark level in one understanding-well sample, and manganese was detected at concentrations greater than the benchmark level in three understanding-well samples (table 8).

Chloride concentrations were greater than the recommended SM CL-CA of $250 \mathrm{mg} / \mathrm{L}$ in four grid-well samples. Chloride was detected at a concentration greater than the upper SM CL-CA of $500 \mathrm{mg} / \mathrm{L}$ in one understandingwell sample. Sulfate concentrations were greater than the recommended SM CL-CA of $250 \mathrm{mg} / \mathrm{L}$ in eight grid-well samples, one of which was also above the upper SM CL-CA of $500 \mathrm{mg} / \mathrm{L}$. Sulfate was detected at a concentration greater than the recommended SM CL-CA in one understanding well. TDS concentrations were greater than the recommended SM CL-CA of $500 \mathrm{mg} / \mathrm{L}$ for $17 \mathrm{grid}$-well samples, 6 of which were also greater than the upper SM CL-CA of $1,000 \mathrm{mg} / \mathrm{L}$. TDS concentrations were greater than the recommended SM CL-CA for five of the six understanding-well samples, one of which was also greater than the upper SM CL -CA (table 10).
A rsenic, chromium, and iron occur as different species depending on the oxidation-reduction state of the groundwater. The oxidized and reduced species have different solubilities in groundwater and may have different effects on human health. The relative proportions of the oxidized and reduced species of each el ement can be used to aid in interpretation of the oxidation-reduction conditions of the aquifer, which affect the mobility of many constituents. Concentrations of total arsenic, chromium, and iron and the dissolved concentration of either the reduced or the oxidized species of these elements are reported in table 11.

\section{Isotopic Tracers}

The isotopic delta values, activities, and abundances of many elements and the concentrations of dissolved gases (including noble gases) may be used as tracers of hydrologic processes (Clark and Fritz, 1997).

Stable isotopes of hydrogen and oxygen in water (table 12) aid in the interpretation of the sources of groundwater recharge (see appendix section titled "N otation" for how the isotope delta values are cal culated). These stable-isotope delta values reflect the altitude, latitude, and temperature of precipitation and also the extent of evaporation of the water in surface-water bodies or soils prior to infiltration into the aquifer.

Tritium activities (table 12) and helium isotope ratios provide information about the age (time since recharge) of groundwater. Tritium is a short-lived radioactive isotope of hydrogen that is incorporated into the water molecule. Low levels of tritium are produced continuously by interaction of cosmic radiation with the Earth's atmosphere, and a large amount of tritium was produced as a result of atmospheric testing of nuclear weapons between 1952 and 1963. Thus, concentrations of tritium greater than background generally indicate the presence of water recharged after the early 1950s. Helium isotope ratios are used in conjunction with tritium concentrations to estimate ages for young groundwater. Of the isotope-tracer constituents analyzed for this study, tritium is the only one with a health-based benchmark. All measured tritium activities in samples from the Santa B arbara study unit were less than 1/1,000 of the M CL-CA benchmark (table 12).

Carbon-14 (table 12), a radioactive isotope of carbon, is also an age-dating tracer. Low levels of carbon-14 are produced continuously by interaction of cosmic radiation with the Earth's atmosphere and incorporated into atmospheric carbon dioxide. Carbon dioxide dissolves in precipitation, surface water, and groundwater exposed to the atmosphere, thereby entering the hydrologic cycle. B ecause carbon-14 decays with a half-life of approximately 5,700 years, low activities of carbon-14, relative to modern values, generally indicate a presence of groundwater that is several thousand years old or more. 


\section{Radioactive Constituents}

R adioactivity is the release of energy or energetic particles during changes in the structure of the nucleus of an atom. M ost radioactivity in groundwater comes from decay of naturally occurring isotopes of uranium and thorium that are present in minerals in the sediments or fractured rocks of the aquifer. U ranium and thorium decay in a series of steps eventually forming stable isotopes of lead (Soddy, 1913; Faure and $M$ ensing, 2005). In each step in the decay series, one radioactive el ement turns into a different radioactive el ement by emitting an alpha or a beta particle from its nucleus. The al pha and beta particles emitted during radioactive decay may be hazardous to human health because these energetic particles may damage cells. Radiation damage to cell DNA may increase the risk of getting cancer.

A ctivity often is used instead of concentration for reporting the presence of radioactive constituents. A ctivity of radioactive constituents in groundwater is measured in units of picocuries per liter ( $\mathrm{pCi} / \mathrm{L})$, and $1 \mathrm{pCi} / \mathrm{L}$ is approximately equal to two atoms decaying per minute. The number of atoms decaying is equal to the number of al pha or beta particles emitted.

Radon-222 was sampled for at 22 of the 24 wells in the Santa B arbara study unit. Radon-222 activity was less than the proposed MCL-US of $4,000 \mathrm{pCi} / \mathrm{L}$ in all sampled wells (table 13A). The proposed M CL-US will apply if the state or local water agency has an approved multimedia mitigation program to address radon levels in indoor air (U.S. Environmental Protection A gency, 1999). A ctivities in all grid- and understanding-well samples for gross al pha and gross beta radioactivity were less than established healthbased benchmarks (table 13B).

\section{Future Work}

Subsequent reports for the Santa B arbara study unit will be focused on assessment of the data presented in this report by using a variety of statistical, qualitative, and quantitative approaches to evaluate the natural and human factors affecting groundwater quality in the Santa $B$ arbara study unit. Water-qual ity data contained in the CDPH databases will be compiled, evaluated, and used in combination with the data that are presented in this report. A dditionally, these subsequent reports will include the results for the analysis of stable isotopes of dissolved boron and strontium in water and the LLNL results (dissolved noble gas, tritium, and helium isotope ratios) for the Santa B arbara study unit.

\section{Summary}

Groundwater quality in the 48-square-mile Santa B arbara study unit was investigated by the U.S. Geological Survey (USGS) from J anuary to February 2011, as part of the California State Water Resources Control B oard (SW RCB) Groundwater A mbient M onitoring and A ssessment (GAMA) Program's Priority B asin Project (PBP). The GA M A

Program was created to provide a comprehensive baseline of groundwater quality in the State. The GA M A-PBP was created as a result of the Groundwater Quality M onitoring A ct of 2001 (Sections 10780-10782.3 of the California Water Code, A ssembly Bill 599) to assess and monitor the quality of groundwater. The GAM A-PBP is being conducted by the USGS in cooperation with the SWRCB and Lawrence Livermore National Laboratory (LLNL).

The GA M A Santa B arbara study was designed to provide a spatially unbiased assessment of untreated-groundwater quality within the primary aquifer system and to facilitate statistically consistent comparisons of untreated-groundwater quality throughout $C$ alifornia. The primary aquifer system is defined as the depth intervals of the wells listed in the California Department of Public Health (CDPH) database for the Santa B arbara study unit. The quality of groundwater in shallow or deeper water-bearing zones may differ from that in the primary aquifer system; shallow groundwater may be more vulnerable to surficial contamination.

This study did not attempt to evaluate the quality of water delivered to consumers; after withdrawal from the ground, water typically is treated, disinfected, and blended with other waters to maintain acceptable water quality. Regulatory benchmarks apply to treated water that is served to the consumer, not to untreated groundwater. However, to provide some context for the results, concentrations of constituents measured in the untreated groundwater were compared with regulatory and non-regulatory heal th-based benchmarks established by the U.S. Environmental Protection A gency (USEPA) and CDPH and non-regulatory benchmarks established for aesthetic concerns by the CDPH.

The Santa B arbara study unit is located within the Transverse and selected Peninsular Ranges hydrologic province and includes five groundwater basins defined by the California Department of Water R esources. The Santa $B$ arbara study included assessment of the groundwater quality from 24 wells in Santa B arbara County. Eighteen wells were selected by using a randomized grid approach to achieve a statistically unbiased representation of groundwater used for public drinking-water supplies (grid wells), and six additional wells were selected to aid in the evaluation of water-quality issues (understanding wells). 
Groundwater samples were analyzed for field waterquality indicators, organic constituents, special-interest constituents, inorganic constituents, and radioactive constituents. $\mathrm{N}$ aturally occurring isotopes and dissolved noble gases also were measured to provide a dataset that will be used to interpret the sources and ages of the sampled groundwater. In total, 281 constituents and water-quality indicators were measured for this study. This report describes the sampling, analytical, and quality-assurance methods used in the study, and presents the results of the chemical analyses of the groundwater samples.

Three types of quality-control samples (blanks, replicates, and matrix spikes) were collected at up to 12 percent of the wells in the Santa B arbara study unit, and the results for these samples were used to evaluate the quality of the data for the groundwater samples. Blanks rarely contained detectable concentrations of any constituent, suggesting that contamination from sample collection procedures was not a significant source of bias in the data for the groundwater samples. Replicate samples generally were within the limits of acceptable analytical reproducibility. M atrix-spike recoveries were within the acceptable range (70 to 130 percent) for approximately 87 percent of the compounds.

All constituents were sampled for at all 24 wells in the Santa B arbara study unit, and most detections had concentrations less than drinking-water benchmarks.

In the grid-well samples, one detection of boron was greater than the CDPH notification level (NL-CA), and one detection of fluoride was greater than the $\mathrm{CDPH}$ maximum contaminant level (M CL-CA). The following constituents had concentrations in grid-well samples greater than their $\mathrm{CDPH}$ secondary maximum contaminant levels (SM CL -CA): 3 detections of iron, 7 detections of manganese, 4 detections of chloride, 8 detections of sulfate ( 1 of which was also greater than the SM CL-CA upper benchmark), and 17 detections of TDS (6 of which were also greater than the SM CL-CA upper benchmark).

In the understanding-well samples, one detection of barium was greater than the MCL-CA, one detection of boron was greater than the NL-CA, and one detection of strontium was greater than the USEPA lifetime heal th advisory level (HAL-US). Three detections of manganese were greater than the SM CL -CA. One detection of chloride was greater than the recommended and upper SMCL-CA, one detection of sulfate was greater than the SMCL-CA, and five detections of TDS were greater than the recommended SM CL-CA (one detection was also greater than the upper SM CL-CA).

\section{Acknowledgments}

The authors thank the following cooperators for their support: the California State Water Resources Control B oard, California Department of Public Health, California Department of Water Resources, and L awrence Livermore $N$ ational L aboratory. We especially thank the well owners and water purveyors for allowing the U.S. Geological Survey to collect samples from their wells.

\section{References Cited}

A merican Public Heal th A ssociation, 1998, Standard methods for the examination of water and wastewater (20th ed.): Washington, D.C., A merican Public Health A ssociation, A merican Water Works A ssociation, and Water Environment Federation, p. 3-37-3-43.

A merican Society for Testing and M aterials, 1998, Water and Environmental Technology, in A nnual B ook of A STM Standards: Philadel phia, Pa., A merican Society for Testing and M aterials, section 11.02 (Water II), p. 664-666.

A nderson, R.L., 1987, Practical statistics for analytical chemists: N ew York, Van N ostrand Reinhold Company, Inc., $315 \mathrm{p}$.

Ball, J.W., and M cCleskey, R.B., 2003a, A new cationexchange method for accurate field speciation of hexavalent chromium: U.S. Geological Survey Water-Resources Investigations Report 03-4018, $17 \mathrm{p}$.

Ball, J.W., and M cCleskey, R.B., 2003b, A new cationexchange method for accurate field speciation of hexavalent chromium: Talanta, v. 61, p. 305-313.

B elitz, K enneth, Dubrovsky, N.M ., B urow, K .R ., Jurgens, B ryant, and J ohnson, Tyler, 2003, Framework for a groundwater quality monitoring and assessment program for California: U.S. G eological Survey Water-Resources Investigations Report 03-4166, 78 p.

Bullen, T.D., K rabbenhoft, D.P., and K endall, Carol, 1996, $K$ inetic and mineralogic controls on the evolution of groundwater chemistry and ${ }^{87} \mathrm{Sr} /{ }^{86} \mathrm{Sr}$ in a sandy silicate aquifer, northern Wisconsin, USA : Geochimica et Cosmochimica A cta, v. 60, no. 10, p. 1807-1821. 
California D epartment of Public Health, 2008a, California drinking water-related laws - D rinking water-related regulations, Title 22: California D epartment of Public Health, accessed October 27, 2011, at http://www.cdph. ca.gov/certlic/drinkingwater/Pages/L awbook.aspx.

California D epartment of Public Health, 2008b, Drinking water notification levels-Notification levels: California Department of Public Health, accessed October 27, 2011, at http://www.cdph.ca.gov/certlic/drinkingwater/Pages/ NotificationLevels.aspx.

California D epartment of Water Resources, 2003, California's groundwater update 2003: Cal ifornia Department of Water Resources Bulletin 118, 246 p., accessed October 27, 2011, at http://www.water.ca.gov/groundwater/bulletin118/ update2003.cfm.

California Department of Water Resources, 2004a, California's groundwater-Individual basin descriptions, Carpinteria: California Department of Water R esources B ull letin 118, accessed A pril 6, 2011, at http://www.water.ca.gov/pubs/ groundwater/bulletin_118/basindescriptions/3-18.pdf.

California Department of Water Resources, 2004b, California's groundwater-Individual basin descriptions, Foothill: California Department of Water R esources Bulletin 118, accessed A pril 6, 2011, at http://www.water.ca.gov/pubs/ groundwater/bulletin_118/basindescriptions/3-53.pdf.

California Department of Water Resources, 2004c, California's groundwater-Individual basin descriptions, Goleta: California Department of Water R esources B ulletin 118, accessed A pril 6, 2011, at http://www.water.ca.gov/pubs/ groundwater/bulletin_118/basindescriptions/3-16.pdf.

California Department of Water Resources, 2004d, California's groundwater-Individual basin descriptions, M ontecito: California Department of Water R esources B ulletin 118, accessed A pril 6, 2011, at http://www.water.ca.gov/pubs/ groundwater/bulletin_118/basindescriptions/3-49.pdf.

California Department of Water Resources, 2004e, California's groundwater-Individual basin descriptions, Santa B arbara: California Department of Water R esources Bulletin 118, accessed A pril 6, 2011, at http://www.water.ca.gov/pubs/ groundwater/bulletin_118/basindescriptions/3-17.pdf.

California State Water Resources Control B oard, 2003, Report to the Governor and Legislature, A comprehensive groundwater quality monitoring program for California: A ssembly Bill 599 M arch 2003, 121 p., accessed October 27, 2011, at http://www.waterboards.ca.gov/gama/ docs/final_ab_599_rpt_to_legis_7_31_03.pdf.
California State Water Resources Control B oard, 2009, Geotracker GA M A : State Water Resources Control B oard database, accessed O ctober 27, 2011, at https://geotracker. waterboards.ca.gov/gama/.

California State Water Resources Control B oard, 2011, GA M A - Groundwater A mbient M onitoring and A ssessment Program: State Water Resources Control B oard website, accessed A pril 6, 2011, at http://www.waterboards. ca.gov/water_issues/programs/gama/.

Childress, C.J.O., Foreman, W.T., Connor, B.F., and M aloney, T.J., 1999, N ew reporting procedures based on long-term method-detection levels and some considerations for interpretations of water-quality data provided by the U.S. Geological Survey National Water Quality Laboratory: U.S. Geological Survey Open-File R eport 99-193, 19 p.

Clark, I.D., and Fritz, P., 1997, Environmental isotopes in hydrogeology: B oca Raton, Florida, CRC Press LLC, 328 p.

Connor, B.F., Rose, D.L., N oriega, M .C., M urtagh, L.K., and A bney, S.R., 1998, M ethods of analysis by the U.S. Geological Survey N ational Water Quality L aboratory-D etermination of 86 volatile organic compounds in water by gas chromatography/mass spectrometry, including detections less than reporting limits: U.S. Geological Survey Open-File Report 97-829, 78 p.

Coplen, T.B., 1994, Reporting of stable hydrogen, carbon, and oxygen isotopic abundances: Pure and A pplied Chemistry, v. 66, p. 273-276.

Coplen, T.B., Hopple, J.A ., Bohlke, J.K ., Peiser, H.S., Rieder, S.E., K rouse, H.R., Rosman, K.J.R., Ding, T., Vocke, R.D., J r., Revesz, K .M ., L amberty, A ., Taylor, P., and DeBierve, P., 2002, Compilation of minimum and maximum isotope ratios of selected el ements in naturally occurring terrestrial materials and reagents: U.S. Geological Survey Water-Resources Investigations Report 01-4222, $98 \mathrm{p}$.

Coplen, T.B., Wildman, J.D., and Chen, J., 1991, Improvements in the gaseous hydrogen-water equilibrium technique for hydrogen isotope analysis: A nalytical Chemistry, v. 63, p. 910-912.

Donahue, D.J ., Linick, T.W., and J ull, A .J .T., 1990, Isotoperatio and background corrections for accelerator mass spectrometry radiocarbon measurements: Radiocarbon, v. 32 , book 2, p. 135-142.

Dwyer, G.S., and Vengosh, A., 2008, Alternative filament loading solution for accurate analysis of boron isotopes by negative thermal ionization mass spectrometry: Eos Transactions A GU, v. 89, no. 53, A bstract H51C-0824. 
Eaton, G.F., Hudson, G.B., and M oran, J .E., 2004, Tritiumhelium-3 age-dating of groundwater in the Livermore Valley of California: A merican Chemical Society A CS Symposium Series, v. 868, p. 235-245.

Epstein, Samuel, and M ayeda, T.K., 1953, Variation of $0^{18}$ content of water from natural sources: Geochimica et Cosmochimica A cta, v. 4, p. 213-224.

Faires, L.M ., 1993, M ethods of analysis by the U.S. Geological Survey National Water Quality L aboratory - D etermination of metals in water by inductively coupled plasma-mass spectrometry: U.S. Geological Survey Open-File Report 92-634, 28 p.

Farrar, J.W., and L ong, H.K., 1997, Report on the U.S. Geological Survey's evaluation program for standard reference samples distributed in September 1996- T-143 (trace constituents), T-145 (trace constituents), M -140 (major constituents), N-51 (nutrient constituents), P-27 (low ionic strength constituents), and $\mathrm{Hg}-23$ (mercury): U.S. Geological Survey Open-File Report 97-20, 145 p.

Faure, Gunter, and M ensing, T.M ., 2005, I sotopesPrinciples and A pplications ( $3 d$ ed.): Hoboken, N ew Jersey, J ohn Wiley \& Sons, Inc., 897 p.

Fishman, M.J., 1993, M ethods of analysis by the U.S. Geological Survey National Water Quality Laboratory-D etermination of inorganic and organic constituents in water and fluvial sediments: U.S. Geological Survey Open-File Report 93-125, 217 p.

Fishman, M .J ., and Friedman, L.C., 1989, M ethods for determination of inorganic substances in water and fluvial sediments: U.S. Geological Survey Techniques of WaterResources Investigations, book 5, chap. A 1, 545 p.

Fram, M .S., and B elitz, K enneth, 2011, Occurrence and concentrations of pharmaceutical compounds in groundwater used for public drinking-water supply in California: Science of the Total Environment, v. 409, no. 18, p. 3409-3417. (A Iso available at http://www.sciencedirect. com/science/article/pii/S0048969711005778.)

Fram, M .S., OIsen, L.D., and B elitz, Kenneth, 2012, Evaluation of volatile organic compound (VOC) blank data and application of study reporting levels to groundwater data collected for the California GA M A Priority Basin Project, M ay 2004 through September 2010: U.S. Geological Survey Scientific Investigations Report 2012-5139, 94 p.
Furlong, E.T., A nderson, B.D., Werner, S.L., Soliven, P.P., Coffey, L.J., and Burkhardt, M.R., 2001, M ethods of analysis by the U.S. Geological Survey National Water Quality Laboratory-D etermination of pesticides in water by graphitized carbon-based solid-phase extraction and high-performance liquid chromatography/mass spectrometry: U.S. Geological Survey Water-Resources Investigations Report 01-4134, 73 p.

Furlong, E.T., Werner, S.L., A nderson, B.D., and Cahill, J.D., 2008, M ethods of analysis by the U.S. Geological Survey National Water Quality L aboratory-D etermination of human-health pharmaceuticals in filtered water by chemically modified styrene-divinylbenzene resin-based solid-phase extraction and high-performance liquid chromatography/mass spectrometry: U.S. Geological Survey Techniques and M ethods, book 5, chap. B5, $56 \mathrm{p}$.

Gagnon, A .R ., and J ones, G .A., 1993, A M S-graphite target production methods at the Woods Hole O ceanographic Institution during 1986-1991: Radiocarbon, v. 35, book 2, p. 301-310.

Garbarino, J.R., 1999, M ethods of analysis by the U.S. Geological Survey National Water Quality L aboratory-Determination of dissolved arsenic, boron, lithium, selenium, strontium, thallium, and vanadium using inductively coupled plasma-mass spectrometry: U.S. Geological Survey Open-File Report 99-093, 31 p.

Garbarino, J.R., K anagy, J.R., and Cree, M .E., 2006, Determination of elements in natural-water, biota, sediment, and soil samples using collision/reaction cell inductively coupled plasma-mass spectrometry: U.S. Geological Survey Techniques and M ethods, book 5, chap. B 1, 88 p.

Gran, G., 1952, Determination of the equivalence point in potentiometric titration, Part II: A nalyst, v. 77, p. 661.

Hahn, G.J ., and M eeker, W.Q., 1991, Statistical intervals-A guide for practitioners: N ew York, John Wiley $\&$ Sons, $392 \mathrm{p}$.

Hem, J.D., 1985, Study and interpretation of the chemical characteristics of natural water: U.S. Geological Survey Water-Supply Paper 2254, 263 p., 3 pls.

H oaglin, D.C., 1983, L etter values-A set of selected order statistics, in Hoaglin, D.C., M osteller, F., and Tukey, J.W., eds., Understanding robust and exploratory data analysis: N ew York, John Wiley \& Sons, p. 33-54. 
Izbicki, J.A ., Swarzenski, P.W., Reich, C.D ., Rollins, C., and Holden, P.A ., 2009, Sources of fecal indicator bacteria in urban streams and ocean beaches, Santa B arbara, Cal ifornia: A nnals of Environmental Science, v. 3, p. 139-178, accessed M arch 27, 2013, at http://iris.lib.neu.edu/cgi/ view content. cgi article $=1034 \&$ context $=$ aes.

K enny, J.F., B arber, N.L., Hutson, S.S., Linsey, K.S., L ovelace, J.K., and M aupin, M .A., 2009, Estimated use of water in the U nited States in 2005: U.S. Geological Survey Circular 1344, $52 \mathrm{p}$.

Kolpin, D.W., Furlong, E.T., M eyer, M .T., Thurman, E.M ., Zaugg, S.D., B arber, L.B., and Buxton, H.T., 2002, Pharmaceuticals, hormones and other organic wastewater contaminants in U.S. streams, 1999-2000: Environmental Science \& Technology, v. 36, no. 6, p. 1202-1211.

K oterba, M .T., Wilde, F.D., and L apham, W.W., 1995, Groundwater data-collection protocols and procedures for the N ational Water-Q ual ity A ssessment ProgramCollection and documentation of water-quality samples and related data: U.S. Geological Survey Open-File Report 95-399, $113 \mathrm{p}$.

K rieger, H.L., and W hittaker, E.L., 1980, Prescribed procedures for measurement of radioactivity in drinking water: U.S. Environmental Protection A gency EPA-600-4-80-032, 142 p. (A Iso available as PB 80-224744 at http://www.ntis.gov.)

K ulongoski, J.T., and B elitz, K enneth, 2004, Groundwater A mbient $M$ onitoring and A ssessment Program: U.S. Geological Survey Fact Sheet 2004-3088, 2 p.

L andon, M .K ., Belitz, K enneth, J urgens, B.C., Kulongoski, J.T., and J ohnson, T.D., 2010, Status and understanding of groundwater quality in the CentralEastside San Joaquin Basin, 2006: California GA M A Priority Basin Project: U.S. Geological Survey Scientific Investigations Report 2009-5266, 97 p.

L ane, S.L., Flanagan, Sarah, and Wilde, F.D., 2003, Selection of equipment for water sampling (ver. 2.0): U.S. G eological Survey Techniques of Water-R esources Investigations, book 9 , chap. A 2, accessed 0 ctober 27, 2011, at http://pubs. water.usgs.gov/twri9A 2/.

Lewis, M .E., 2006, Dissolved oxygen (ver. 2.1): U.S. Geological Survey Techniques of Water-Resources Investigations, book 9, chap. A 6.2, accessed 0 ctober 27, 2011, at http://pubs.water.usgs.gov/twri9A 6.2/.

Lian, H.M ., 1954, Geology of the Carpinteria district, Santa B arbara County, in Geology of southern California: California Division of M ines and Geology Bulletin 170, map sheet 25.
Lindley, C.E., Stewart, J.T., and Sandstrom, M.W., 1996, Determination of low concentrations of acetochlor in water by automated solid-phase extraction and gas chromatography with mass selective detection: J ournal of A OA C International, v. 79, no. 4, p. 962-966.

M adsen, J.E., Sandstrom, M .W., and Zaugg, S.D., 2003, M ethods of analysis by the U.S. Geological Survey National Water Quality Laboratory-A method supplement for the determination of fipronil and degradates in water by gas chromatography/mass spectrometry: U.S. Geological Survey O pen-File Report 02-462, 11 p.

M aloney, T.J ., ed., 2005, Q uality management system, U.S. Geological Survey National Water Quality Laboratory: U.S. Geological Survey Open-File R eport 2005-1263, accessed October 27, 2011, at http://pubs.usgs.gov/ of/2005/1263/.

M cCleskey, R.B., N ordstrom, D.K., and B all, J.W., 2003, $M$ etal interferences and their removal prior to the determination of $A s(T)$ and $A s(I I I)$ in acid mine waters by hydride generation atomic absorption spectrometry: U.S. Geological Survey Water-Resources Investigations Report 03-4117, $14 \mathrm{p}$.

M cCurdy, D.E., Garbarino, J.R., and M ullin, A.H., 2008, Interpreting and reporting radiological water-quality data: U.S. Geological Survey Techniques and M ethods, book 5, chap. B6, 33 p.

M CL ain, B ., 1993, M ethods of analysis by the U.S. Geological Survey $N$ ational Water Quality L aboratory- Determination of chromium in water by graphite furnace atomic absorption spectrophotometry: U.S. Geological Survey O pen-File Report 93-449, 16 p.

M cNichol, A .P., Gagnon, A .R., J ones, G.A., and Osborne, E.A., 1992, Illumination of a black box-A nalysis of gas composition during graphite target preparation, in L ong, A., and K ra, R.S., eds., Proceedings of the 14th International ${ }^{14} \mathrm{C}$ Conference: Radiocarbon, v. 34, book 3, p. 321-329.

M cNichol, A .P., J ones, G.A ., Hutton, D.L., and Gagnon, A.R., 1994, The rapid preparation of seawater $\sum \mathrm{CO}_{2}$ for radiocarbon analysis at the $\mathrm{N}$ ational $\mathrm{O}$ cean Sciences A M S Facility: Radiocarbon, v. 36, book 2, p. 237-246.

M inor, S.A., K ellogg, K.S., Stanley, R.G., Gurrola, L.D., K eller, E.A., and B randt, T.R., 2009, Geologic map of the Santa B arbara Coastal Plain area, Santa B arbara County, California: U.S. Geological Survey Scientific Investigations M ap 3001, scale 1:25,000, 1 sheet, pamphlet, 38 p.

M oran, J.E., Hudson, G.B ., Eaton, G.F., and L eif, R., 2002, A contamination vul nerability assessment for the L ivermore-A mador and Niles Cone Groundwater B asins: $L$ awrence Livermore $N$ ational $L$ aboratory internal report UCRL-AR-148831, 25 p. 
M ueller, D.K., and Titus, C.J ., 2005, Quality of nutrient data from streams and ground water sampled during water years 1992-2001: U.S. Geological Survey Scientific Investigations Report 2005-5106, 27 p.

Olsen, L.D., Fram, M.S., and B elitz, K enneth, 2010, Review of trace-element field-blank data collected for the California Groundwater A mbient M onitoring and A ssessment (GA M A) Program, M ay 2004-January 2008: U.S. Geological Survey Scientific Investigations Report 2009-5220, 47 p.

Patton, C.J., and K ryskalla, J.R., 2003, M ethods of analysis by the U.S. Geological Survey National Water Quality Laboratory-Evaluation of al kaline persulfate digestion as an alternative to $\mathrm{K}$ jeldahl digestion for determination of total and dissolved nitrogen and phosphorous in water: U.S. Geological Survey Water-R esources Investigations Report 03-4174, $33 \mathrm{p}$.

Pirkey, K.D., and Glodt, S.R., 1998, Quality control at the U.S. G eological Survey National Water Quality L aboratory: U.S. G eological Survey Fact Sheet 026-98, 4 p., accessed October 27, 2011, at http://pubs.er.usgs.gov/usgspubs/fs/ fs02698.

Plomley, J.B ., K oester, C.J ., and M arch, R.E., 1994, Determination of NDM A in complex environmental matrices by quadrupole ion storage tandem mass spectrometry enhanced by unidirectional ion ejection: A nalytical Chemistry, v. 66, no. 24, p. 4437-4443.

Radtke, D.B., Davis, J.V., and Wilde, F.D., 2005, Specific electrical conductance (ver. 1.2): U.S. G eological Survey Techniques of Water-Resources Investigations, book 9 , chap. A 6.3, accessed October 27, 2011, at http://pubs.water. usgs.gov/twri9A 6.3/.

Sandstrom, M .W., Stroppel, M .E., Foreman, W.T., and Schroeder, M .P., 2001, M ethods of analysis by the U.S. Geological Survey National Water Quality L aboratory-D etermination of moderate-use pesticides and selected degradates in water by $\mathrm{C}-18$ solid-phase extraction and gas chromatography/mass spectrometry: U.S. G eological Survey Water-Resources Investigations Report 01-4098, $70 \mathrm{p}$.

Schneider, R.J., Jones, G.A ., M cNichol, A .P., von Reden, K .F., Elder, K.A., Huang, K., and K essel, E.D., 1994, Methods for data screening, flagging, and error analysis at the $\mathrm{N}$ ational $O$ cean Sciences A M S Facility: N uclear Instruments and M ethods in Physics Research, book 92, p. 172-175.

Scott, J.C., 1990, Computerized stratified random site selection approaches for design of a groundwater quality sampling network: U.S. Geological Survey Water-Resources Investigations Report 90-4101, 109 p.
Shelton, J.L., B urow, K.R., B elitz, K enneth, Dubrovsky, N.M ., L and, M .T., and Gronberg, J.M ., 2001, Low-level volatile organic compounds in active public supply wells as groundwater tracers in the L os A ngeles physiographic basin, California, 2000: U.S. Geological Survey Water-R esources Investigations Report 01-4188, 29 p.

Soddy, F., 1913, Radioactivity: A nnual Reports on the Progress of Chemistry, v. 10, p. 262-288.

State of California, 2001a, A ssembly Bill N 0. 599, Chapter 522, accessed October 27, 2011, at http://www. swrcb.ca.gov/gama/docs/ab_599_bill_20011005_chaptered. pdf.

State of California, 2001b, Groundwater M onitoring A ct of 2001: California Water Code, part 2.76, Sections 1078010782.3, accessed October 27, 2011, at http://www.leginfo. ca.gov/cgi-bin/displaycode?section $=$ wat\& group $=10001$ 11000\&file $=10780-10782.3$.

Stookey, L.L., 1970, FerroZine-A new spectrophotometric reagent for iron: A nalytical Chemistry, v. 42, p. 779-781.

Thatcher, L.L., J anzer, V.J ., and Edwards, K.W., 1977, $M$ ethods for the determination of radioactive substances in water: U.S. G eological Survey Techniques of WaterResources Investigations, book 5, chap. A 5, 95 p.

Timme, P.J ., 1995, N ational Water Quality Laboratory 1995 services catal og: U.S. Geological Survey Open-File Report 95-352, $120 \mathrm{p}$.

To, T.B ., Nordstrom, D.K., Cunningham, K.M., B all, J.W., and M cCleskey, R.B., 1998, New method for the direct determination of dissolved $\mathrm{Fe}(\mathrm{III})$ concentration in acid mine waters: Environmental Science \& Technology, v. 33, p. 807-813.

U.S. Department of Commerce, $N$ ational O ceanic and A tmospheric A dministration, 2010, National Climatic Data Center, accessed October 27, 2011, at http://www1.ncdc. noaa.gov/pub/orders/IPS-FC 06B F 11-2768-478F -B 77B 771EEE910A 2B.pdf.

U.S. Environmental Protection A gency, 1989, Semivolatile organic compounds by isotope dilution GSM S (J uly 1989): Washington, D.C., U.S. Environmental Protection A gency, $68 \mathrm{p}$.

U.S. Environmental Protection A gency, 1999, National primary drinking water regulations, Radon-222: Federal Register, v. 64, no. 211, p. 59, 245-259, and 294.

U.S. Environmental Protection A gency, 2002, Guidelines for establishing procedures for the analysis of pollutants: U.S. Code of Federal Regulations, Title 40, 136 p. 
U.S. Environmental Protection A gency, 2005, M ethod 331.0Determination of perchlorate in drinking water by liquid chromatography electrospray ionization mass spectrometry (Revision 1.0, January 2005): Office of Groundwater and Drinking Water, EPA Document \# 815-R-05-007, 34 p., accessed October 27, 2011, at http://www.epa.gov/ safewater/methods/pdfs/methods/met331_0.pdf.

U.S. Environmental Protection A gency, 2008a, D rinking water contaminants, accessed J uly 12, 2010, at http://www.epa. gov/safewater/contaminants/index.html.

U.S. Environmental Protection A gency, 2008b, D rinking water heal th advisories- 2006 D rinking water standards and health advisory tables, accessed October 27, 2011, at http:// www.epa.gov/waterscience/criteria/drinking/.

U.S. Environmental Protection A gency, 2008c, Proposed radon in drinking water rule, accessed 0 ctober 27, 2011, at http://www.epa.gov/ogwdw/radon/proposal.html.

U.S. Geological Survey, 2011a, W hat is the Priority Basin Project?: California Water Science Center website, accessed October 27, 2011, at http://ca.water.usgs.gov/gama/.

U.S. Geological Survey, 2011b, Publications: California Water Science Center website, accessed October 27, 2011, at http://ca.water.usgs.gov/gama/includes/GA M A publications.html.

U.S. Geological Survey, 2011c, B ranch of Quality Systems, Inorganic Blind Sample Project (IBSP) QADATA summaries, accessed October 27, 2011, at http://bqs.usgs. gov/ibsp/qadata.shtml.

U.S. Geological Survey, 2011d, B ranch of Quality Systems, Inorganic Blind Sample Project (IBSP) NW Q L control charts for fiscal year 2011 analytes, accessed October 27, 2011, at http://bqs.usgs.gov/ibsp/FY 11charts.shtml.

U.S. Geological Survey, [variously dated], National field manual for the collection of water-quality data: U.S. Geological Survey Techniques of Water-R esources Investigations, book 9, chap. A 1-A 9, accessed 0 ctober 27, 2011, at http://water.usgs.gov/owq/F ieldM anual/.

U.S. Geological Survey Office of Water Quality, 2010, Changes to the reporting convention and to data qualification approaches for selected analyte results reported by the National Water Quality L aboratory (NW QL): U.S. Geological Survey Office of Water Quality Technical M emorandum 2010.07.

Vengosh A ., Chivas, A.R., and M cCulloch M .T., 1989, Direct determination of boron and chlorine isotopes in geological materials by negative thermal ionization mass spectrometry: Chemical Geology, v. 79, p. 333-343.
Vogel, J.S., N elson, D.E., and Southon, J.R., 1987, ${ }^{14} \mathrm{C}$ background levels in an accelerator mass spectrometry system: Radiocarbon, v. 29, book 3, p. 323-333.

Weiss, R.F., 1968, Piggyback sampler for dissolved gas studies on seal ed water samples: Deep Sea Research, v. 15, p. 721-735.

Wilde, F.D., ed., 2004, Cleaning of equipment for water sampling (ver. 2.0): U.S. Geological Survey Techniques of Water-Resources Investigations, book 9, chap. A 3, accessed October 27, 2011, at http://pubs.water.usgs.gov/twrigA 3/.

Wilde, F.D., 2006, Temperature (ver. 2): U.S. Geological Survey Techniques of Water-Resources Investigations, book 9, chap. A6.1, accessed October 27, 2011, at http:// pubs.water.usgs.gov/twrigA 6.1/.

Wilde, F.D., B usenberg, E., and Radtke, D.B., 2006, pH (ver. 1.3): U.S. G eological Survey Techniques of WaterResources Investigations, book 9, chap. A 6.4, accessed October 27, 2011, at http://pubs.water.usgs.gov/twri9A 6.4/.

Wilde, F.D., and Radtke, D.B., 2005, General information and guidelines (ver. 1.2): U.S. Geological Survey Techniques of Water-Resources Investigations, book 9, chap. A 6.0, accessed October 27, 2011, at http://pubs.water.usgs.gov/ twri9A 6.0/.

Wilde, F.D., Radtke, D.B., Gibs, J., and I watsubo, R .T., 1999, Collection of water samples: U.S. G eological Survey Techniques of Water-R esources Investigations, book 9 , chap. A 4, accessed October 27, 2011, at http://pubs.water. usgs.gov/twrigA 4/.

Wilde, F.D., Radtke, D.B., Gibs, J., and I watsubo, R.T., 2004, Processing of water samples: U.S. Geological Survey Techniques of Water-R esources Investigations, book 9, chap. A 5, accessed October 27, 2011, at http://pubs.water. usgs.gov/twrigA 5/.

Wright, M .T., B elitz, K enneth, and Burton, C.A., 2005, California GA M A Program-Ground-water quality data in the San Diego D rainages hydrogeologic province, California, 2004: U.S. Geological Survey Data Series 129, 91 p. (Also available at http://pubs.usgs.gov/ds/2005/129.)

Zaugg, S.D., Sandstrom, M.W., Smith, S.G., and Fehlberg, K.M., 1995, M ethods of analysis by the U.S. G eological Survey National Water Quality L aboratory-Determination of pesticides in water by $\mathrm{C}-18$ solid-phase extraction and capillary-column gas chromatography/mass spectrometry: U.S. Geological Survey Open-File R eport 95-181, 60 p.

Zogorski, J.S., Carter, J.M ., Ivahnenko, T., Lapham, W.W., M oran, M.J., Rowe, B.L., Squillace, P.J ., and Toccalino, P.L., 2006, Volatile organic compounds in the $N$ ation's ground water and drinking-water supply wells: U.S. Geological Survey Circular 1292, 101 p. 
Table 1. Identification, sampling, and construction information for wells sampled for the Santa Barbara study unit, January to February 2011, California GAMA Priority Basin Project.

[GAMA well identification number: SB, Santa B arbara study unit grid well; SBU, Santa B arbara study unit understanding well. Other abbreviations: ft, foot; LSD, land surface datum; NAVD 88, N orth A merican Vertical Datum of 1988; na, not available]

\begin{tabular}{|c|c|c|c|c|c|c|}
\hline \multirow[b]{2}{*}{$\begin{array}{c}\text { GAMA well } \\
\text { identification } \\
\text { number }\end{array}$} & \multirow[b]{2}{*}{$\begin{array}{l}\text { Date Sampled } \\
\text { (m/dd/ yyyy) }\end{array}$} & \multirow[b]{2}{*}{$\begin{array}{c}\text { Altitude of LSD } \\
\text { (ft above NAVD 88) }\end{array}$} & \multirow[b]{2}{*}{ Well type } & \multicolumn{3}{|c|}{ Construction information } \\
\hline & & & & $\begin{array}{c}\text { Well depth } \\
\text { (ft below LSD) }\end{array}$ & $\begin{array}{c}\text { Depth to top } \\
\text { perforation } \\
\text { (ft below LSD) }\end{array}$ & $\begin{array}{c}\text { Depth to bottom } \\
\text { perforation } \\
\text { (ft below LSD) }\end{array}$ \\
\hline \multicolumn{7}{|c|}{ Santa Barbara grid wells } \\
\hline SB-01 & $2 / 3 / 2011$ & 47 & Production & 150 & 110 & 150 \\
\hline SB-02 & $2 / 1 / 2011$ & 21 & Production & 840 & 210 & 820 \\
\hline SB -04 & $1 / 31 / 2011$ & 45 & Production & 700 & 180 & 680 \\
\hline SB-05 & $2 / 14 / 2011$ & 363 & Production & 420 & 255 & 410 \\
\hline SB -06 & $2 / 2 / 2011$ & 83 & Production & 630 & 350 & 630 \\
\hline SB-07 & $1 / 26 / 2011$ & 191 & Production & 427 & 215 & 427 \\
\hline SB-11 & $2 / 9 / 2011$ & 26 & Production & 206 & 100 & 206 \\
\hline SB -12 & $2 / 7 / 2011$ & 267 & Production & 140 & na & na \\
\hline SB-13 & $2 / 7 / 2011$ & 81 & Production & 460 & 170 & 460 \\
\hline SB-14 & $2 / 9 / 2011$ & 358 & Production & 975 & 195 & 975 \\
\hline SB-15 & 2/2/2011 & 43 & Production & 958 & 317 & 938 \\
\hline SB-16 & $2 / 3 / 2011$ & 66 & Production & 1,245 & 310 & 1,230 \\
\hline SB -17 & $2 / 16 / 2011$ & 153 & Production & 250 & na & na \\
\hline SB-18 & $2 / 10 / 2011$ & 198 & Production & 295 & 85 & 295 \\
\hline SBU-06 & $2 / 15 / 2011$ & 22 & Unused & 464 & 280 & 464 \\
\hline
\end{tabular}

${ }^{1}$ LSD is a datum plane that is approximately at land surface at each well. The altitude of the LSD is described in feet above the N orth A merican Vertical Datum of 1988. 
Table 2. Classes of chemical constituents and field water-quality indicators collected for the Santa Barbara study unit, January to February 2011, California GAMA Priority Basin Project.

\begin{tabular}{|c|c|c|}
\hline Constituent classes & $\begin{array}{l}\text { Constituent } \\
\text { list table }\end{array}$ & $\begin{array}{c}\text { Results } \\
\text { table }\end{array}$ \\
\hline \multicolumn{3}{|l|}{ Field water-quality indicators } \\
\hline Dissolved oxygen, temperature, $\mathrm{pH}$, and specific conductance & - & 4 \\
\hline Field alkalinity, bicarbonate, and carbonate & - & 4 \\
\hline \multicolumn{3}{|l|}{ Organic constituents } \\
\hline Volatile organic compounds (V OC) & $3 \mathrm{~A}$ & 5 \\
\hline Pesticides and pesticide degradates & 3B & 6 \\
\hline Polar pesticides and degradates & $3 C$ & none ${ }^{1}$ \\
\hline Pharmaceutical compounds & $3 \mathrm{D}$ & none ${ }^{1}$ \\
\hline \multicolumn{3}{|l|}{ Constituents of special interest } \\
\hline Perchlorate & $3 \mathrm{E}$ & 7 \\
\hline N-Nitrosodimethylamine (NDMA) & $3 \mathrm{E}$ & none ${ }^{1}$ \\
\hline \multicolumn{3}{|l|}{ Inorganic constituents } \\
\hline Trace elements & $3 F$ & 8 \\
\hline Nutrients & $3 G$ & 9 \\
\hline M ajor and minor ions, silica, and total dissolved solids (TDS) & $3 \mathrm{H}$ & 10 \\
\hline L aboratory alkalinity, bicarbonate, and carbonate & $3 \mathrm{H}$ & 4 \\
\hline A rsenic, chromium, and iron species & 31 & 11 \\
\hline \multicolumn{3}{|c|}{ Isotopic tracers, dissolved noble gases, and radioactive constituents } \\
\hline Stable isotopes of hydrogen and oxygen in water & 3] & 12 \\
\hline Stable isotopes of carbon in dissolved inorganic carbon and carbon-14 abundance & 3) & 12 \\
\hline Stable isotopes of dissolved boron in water & 3] & none $^{2}$ \\
\hline Isotope ratio of dissolved strontium in water & 3] & none $^{2}$ \\
\hline Tritium & 3] & 12 \\
\hline Stable isotope ratio of helium, dissolved nobles gases, and tritium & $3 \mathrm{~K}$ & none $^{2}$ \\
\hline Radon-222 & 3) & $13 \mathrm{~A}$ \\
\hline Gross alpha and gross beta radioactivity (72-hour and 30-day counts) & 3] & $13 B$ \\
\hline
\end{tabular}

${ }^{1}$ Constituent(s) not detected in groundwater samples.

${ }^{2}$ Results were not completed in time for inclusion in this report; results will be presented in a subsequent publication. 


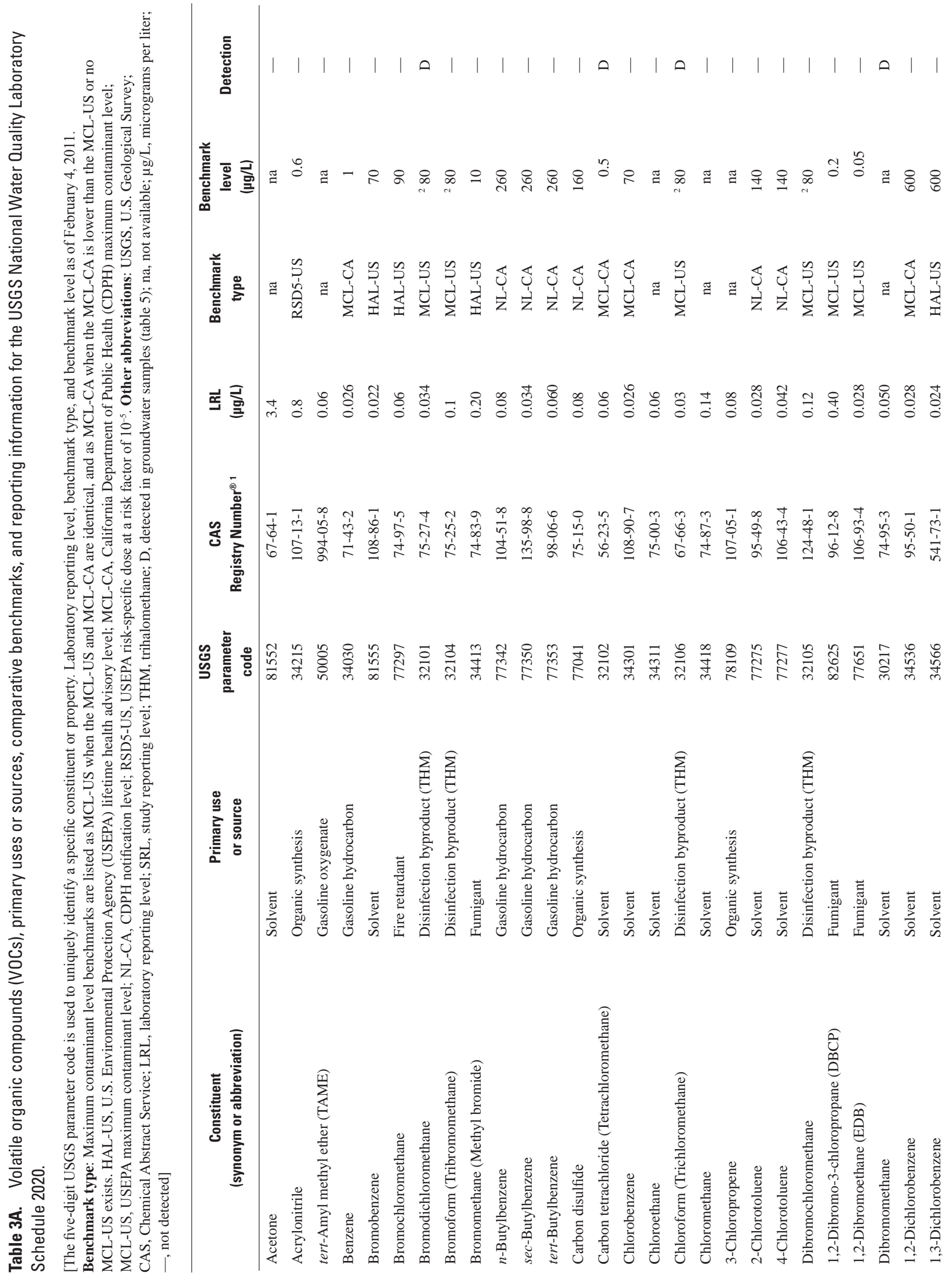




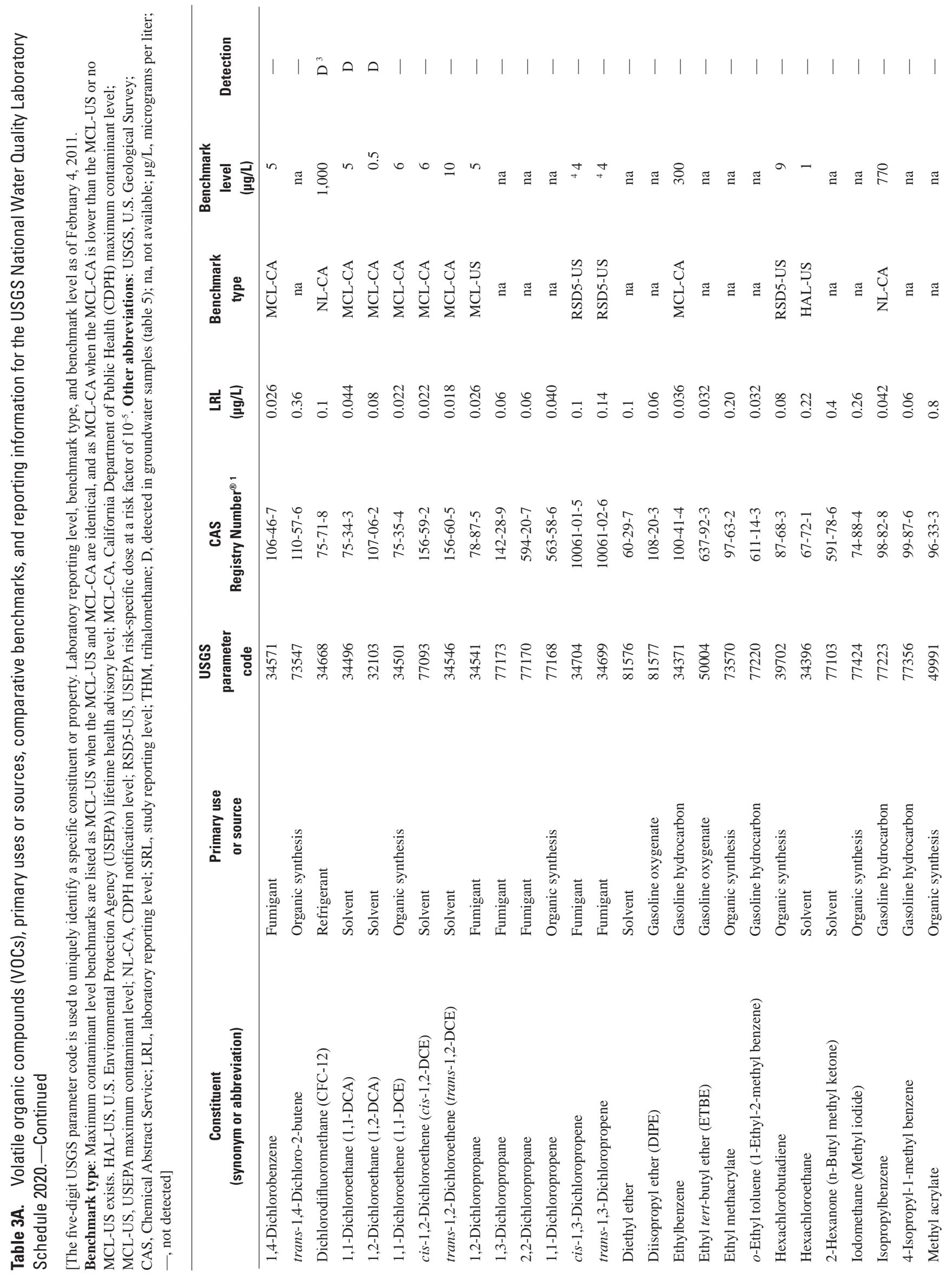




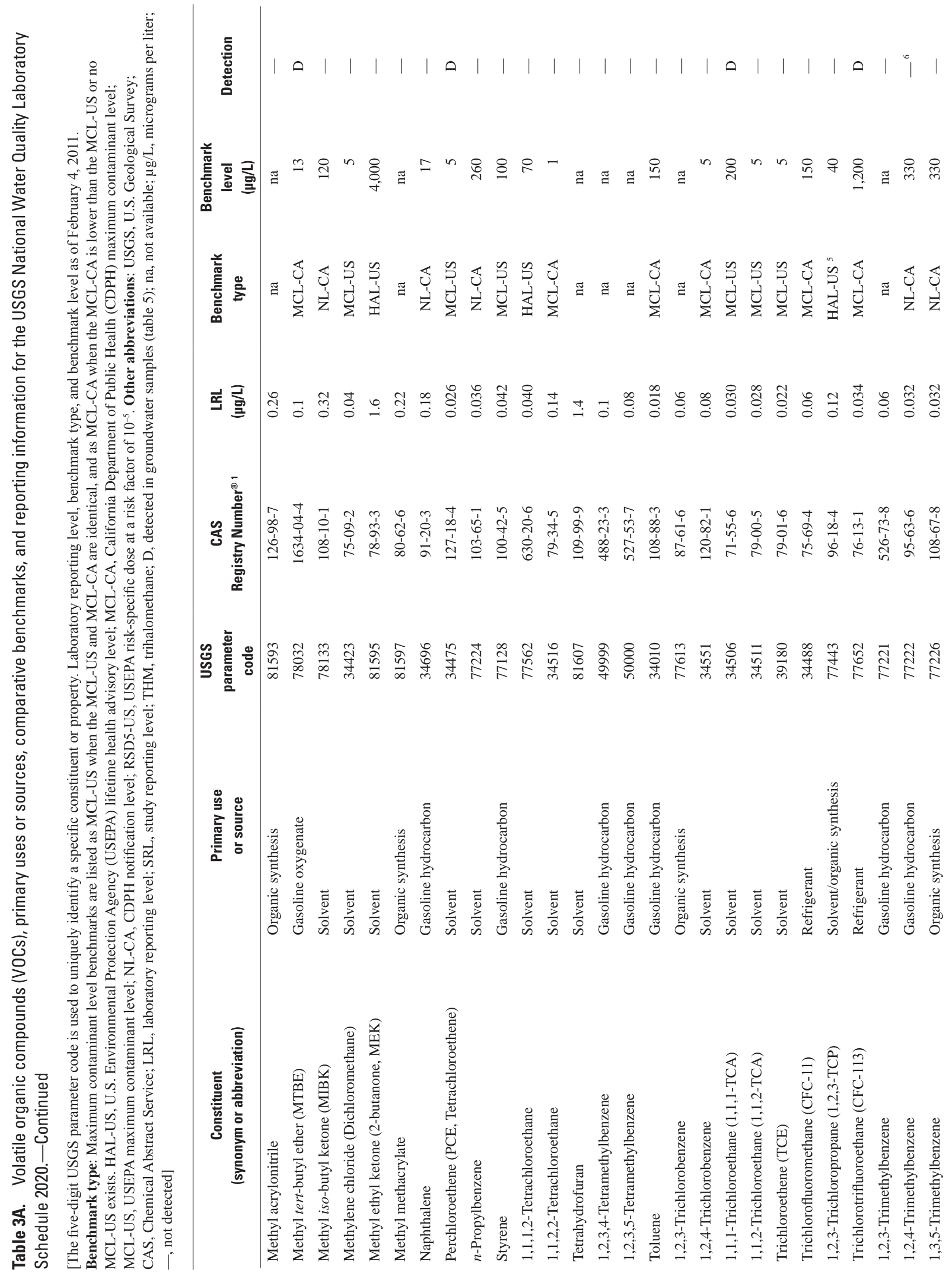







Table 3B. Pesticides and pesticide degradates, primary uses or sources, comparative benchmarks, and reporting information for the USGS National Water Quality Laboratory Schedule 2003.

[The five-digit USGS parameter code is used to uniquely identify a specific constituent or property. Laboratory reporting level, benchmark type, and benchmark level as of February 4, 2011. Benchmark type: M aximum contaminant level benchmarks are listed as M CL-US when the M CL-US and M CL-CA are identical, and as M CL-CA when the M CL-CA is lower than the M CL-US or no M CL-US exists. HAL-US, U.S. Environmental Protection A gency (USEPA) lifetime health advisory level; M CL-CA, California Department of Public Health maximum contaminant level; M CL-US, USEPA maximum contaminant level; RSD5-US, USEPA risk-specific dose at a risk factor of $10^{-5}$. Other abbreviations: USGS, U.S. G eological Survey; CA S, Chemical A bstract Service; $L R L$, laboratory reporting level; $D$, detected in groundwater samples (table 6); na, not available; $\mu \mathrm{g} / \mathrm{L}$, micrograms per liter; - , not detected]




Table 3B. Pesticides and pesticide degradates, primary uses or sources, comparative benchmarks, and reporting information for the USGS National Water Quality Laboratory Schedule 2003.-Continued

[The five-digit USGS parameter code is used to uniquely identify a specific constituent or property. Laboratory reporting level, benchmark type, and benchmark level as of February 4, 2011. Benchmark type: M aximum contaminant level benchmarks are listed as M CL-US when the M CL-US and M CL-CA are identical, and as M CL-CA when the M CL-CA is lower than the M CL-US or no M CL-US exists. HAL-US, U.S. Environmental Protection A gency (USEPA) lifetime health advisory level; M CL-CA, California Department of Public Health maximum contaminant level; M CL-US, USEPA maximum contaminant level; RSD5-US, USEPA risk-specific dose at a risk factor of $10^{-5}$. Other abbreviations: USGS, U.S. Geological Survey; CAS, Chemical A bstract Service; LRL, laboratory reporting level; $D$, detected in groundwater samples (table 6); na, not available; $\mu \mathrm{g} / \mathrm{L}$, micrograms per liter; - , not detected]



${ }^{1}$ The median matrix-spike recovery was less than 70 percent. Low recoveries may indicate that the compound might not have been detected in some samples if it was present at very low concentrations. 
Table 3C. Polar pesticides and degradates, primary uses or sources, comparative thresholds, and reporting information for the USGS National Water Quality Laboratory Schedule 2060.

[The five-digit USGS parameter code is used to uniquely identify a specific constituent or property. Laboratory reporting level, benchmark type, and benchmark level as of February 4, 2011. M aximum contaminant level benchmarks are listed as MCL-US when the M CL-US and MCL-CA are identical, and as M CL-CA when the M CL-CA is lower than the M CL-US or no M CL-US exists. Benchmark type: HAL-US, U.S. Environmental Protection A gency lifetime health advisory level; M CL-CA, California Department of Public Health (CDPH) maximum contaminant level; M CL-US, U.S. Environmental Protection A gency maximum contaminant level; RSD5-US, U.S. Environmental Protection Agency risk-specific dose at a risk factor of $10^{-5}$. Other abbreviations: USGS, U.S. Geological Survey; CA S, Chemical A bstract Service; LRL, laboratory reporting level; na, not available; $\mu \mathrm{g} / \mathrm{L}$, micrograms per liter; - , not detected]

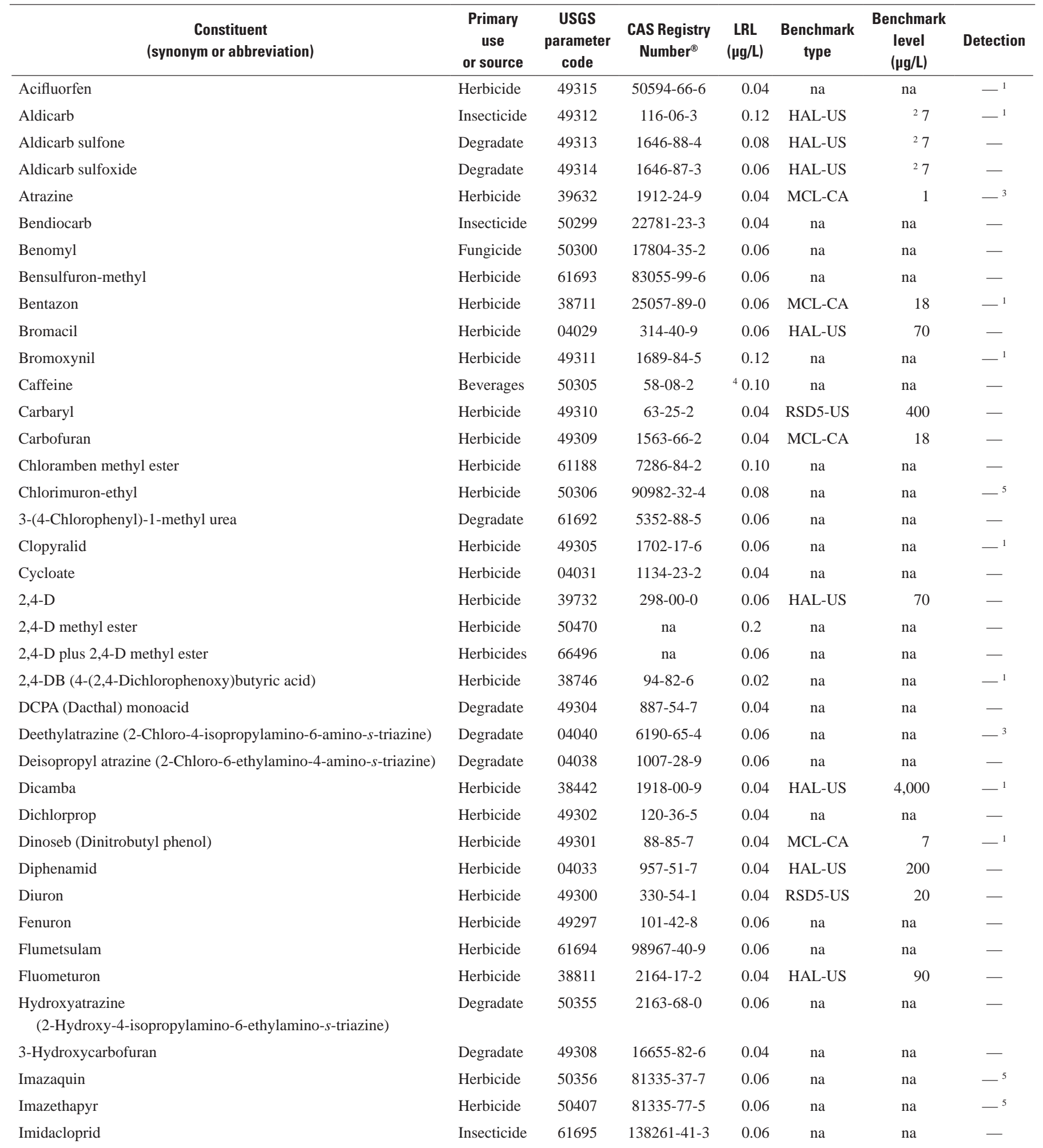


Table 3C. Polar pesticides and degradates, primary uses or sources, comparative thresholds, and reporting information for the USGS National Water Quality Laboratory Schedule 2060.-Continued

[The five-digit USGS parameter code is used to uniquely identify a specific constituent or property. Laboratory reporting level, benchmark type, and benchmark level as of February 4, 2011. M aximum contaminant level benchmarks are listed as M CL-US when the M CL-US and M CL-CA are identical, and as M CL-CA when the M CL-CA is lower than the M CL-US or no M CL-US exists. Benchmark type: HAL-US, U.S. Environmental Protection A gency lifetime health advisory level; M CL-CA, California Department of Public Health (CDPH) maximum contaminant level; M CL-US, U.S. Environmental Protection A gency maximum contaminant level; RSD5-US, U.S. Environmental Protection Agency risk-specific dose at a risk factor of $10^{-5}$. Other abbreviations: USGS, U.S. Geological Survey; CA S, Chemical A bstract Service; LRL, laboratory reporting level; na, not available; $\mu \mathrm{g} / \mathrm{L}$, micrograms per liter; - , not detected]

\begin{tabular}{|c|c|c|c|c|c|c|c|}
\hline $\begin{array}{c}\text { Constituent } \\
\text { (synonym or abbreviation) }\end{array}$ & $\begin{array}{c}\text { Primary } \\
\text { use } \\
\text { or source }\end{array}$ & $\begin{array}{c}\text { USGS } \\
\text { parameter } \\
\text { code }\end{array}$ & $\begin{array}{l}\text { CAS Registry } \\
\text { Number }^{\circledR}\end{array}$ & $\begin{array}{c}\text { LRL } \\
(\mu \mathrm{g} / \mathrm{L})\end{array}$ & $\begin{array}{l}\text { Benchmark } \\
\text { type }\end{array}$ & $\begin{array}{c}\text { Benchmark } \\
\text { level } \\
(\mu \mathrm{g} / \mathrm{L})\end{array}$ & Detection \\
\hline Linuron & Herbicide & 38478 & $330-55-2$ & 0.04 & na & na & - \\
\hline M CPA (2-M ethyl-4-chlorophenoxyacetic acid) & Herbicide & 38482 & $94-74-6$ & 0.04 & HAL-US & 30 & - \\
\hline M CPB (4-(2-M ethyl-4-chlorophenoxy)butyric acid) & Herbicide & 38487 & $94-81-5$ & 0.2 & na & na & -1 \\
\hline M etalaxyl & Fungicide & 50359 & 57837-19-1 & 0.04 & na & na & - \\
\hline M ethomyl & Insecticide & 49296 & $16752-77-5$ & 0.12 & HAL-US & 200 & - \\
\hline M etsulfuron methyl & Herbicide & 61697 & $74223-64-6$ & 0.14 & na & na & - \\
\hline Neburon & Herbicide & 49294 & $555-37-3$ & 0.02 & na & na & - \\
\hline $\mathrm{Nicosulfuron}$ & Herbicide & 50364 & $111991-09-4$ & 0.10 & na & na & $-{ }^{5}$ \\
\hline Norflurazon & Herbicide & 49293 & $27314-13-2$ & 0.04 & na & na & - \\
\hline Propham & Herbicide & 49236 & $122-42-9$ & 0.04 & HAL-US & 100 & - \\
\hline Propiconazole & Fungicide & 50471 & $60207-90-1$ & 0.04 & na & na & - \\
\hline Propoxur & Insecticide & 38538 & $114-26-1$ & 0.06 & HAL-US & 3 & - \\
\hline Siduron & Herbicide & 38548 & $1982-49-6$ & 0.04 & na & na & $-{ }^{5}$ \\
\hline Sulfometuron-methyl & Herbicide & 50337 & $74222-97-2$ & 0.06 & na & na & $-{ }^{5}$ \\
\hline Tebuthiuron & Herbicide & 82670 & 34014-18-1 & 0.06 & HAL-US & 500 & -3 \\
\hline Terbacil & Herbicide & 04032 & $5902-51-2$ & 0.04 & HAL-US & 90 & - \\
\hline Triclopyr & Herbicide & 49235 & $55335-06-3$ & 0.08 & na & na & - \\
\hline
\end{tabular}

${ }^{1}$ The median matrix-spike recovery was less than 70 percent. Low recoveries may indicate that the compound might not have been detected in some samples if it was present at very low concentrations.

${ }^{2}$ The HAL-US benchmark is the sum of aldicarb, aldicarb sulfone, and aldicarb sulfoxide.

${ }^{3}$ Constituent was measured on more than one schedule. See table 3B for results with preferred method.

${ }^{4}$ The California Groundwater A mbient M onitoring and A ssessment (GA M A) Program uses more conservative reporting limits for the pharmaceutical compounds than are used by the USGS National Water Quality Laboratory (NW QL) (Fram and B elitz, 2011). The method detection limit (M DL) corresponds to the highest long-term method detection limit (LT-M DL) or interim method detection limit (I-M DL) used by the NW QL during the period GA M A samples were analyzed (M ay 2004 through J une 2010). Results reported by the NW Q L with concentrations less than the M DLs are reported as non-detections by GAM A. D ata are stored in the USGS N ational Water Information System (NWIS) database as reported by GA M A: results initially reported as detections with concentrations below the M DLs or as non-detections less than LT-M DLs are re-coded as non-detections less than M DLs.

${ }^{5}$ The median matrix-spike recovery was greater than 130 percent. 
Table 3D. Pharmaceutical compounds, primary uses or sources, comparative benchmarks, and reporting information for the USGS National Water Quality Laboratory Schedule 2080.

[The five-digit USGS parameter code is used to uniquely identify a specific constituent or property. Abbreviations: USGS, U.S. Geological Survey; CAS, Chemical A bstract Service; M DL, method detection level; na, not available; $\mu \mathrm{g} / \mathrm{L}$, micrograms per liter]

\begin{tabular}{|c|c|c|c|c|c|c|c|}
\hline Constituent & $\begin{array}{l}\text { Primary use } \\
\text { or source }\end{array}$ & $\begin{array}{c}\text { USGS } \\
\text { parameter } \\
\text { code }\end{array}$ & $\begin{array}{c}\text { CAS } \\
\text { Registry } \\
\text { Number }^{\circledR}\end{array}$ & $\begin{array}{l}M D L^{1} \\
(\mu \mathrm{g} / \mathrm{L})\end{array}$ & $\begin{array}{c}\text { Benchmark } \\
\text { type }\end{array}$ & $\begin{array}{c}\text { Benchmark } \\
\text { level } \\
(\mu \mathrm{g} / \mathrm{L})\end{array}$ & Detection \\
\hline A cetaminophen & A nalgesic & 62000 & $103-90-2$ & 0.06 & na & na & - \\
\hline A lbuterol & Bronchodilator & 62020 & 18559-94-9 & 0.04 & na & na & $-{ }^{2}$ \\
\hline Caffeine & Stimulant & 50305 & $58-08-2$ & 0.10 & na & na & -3 \\
\hline Carbamazapine & A nticonvulsant; mood stabilizer & 62793 & $298-46-4$ & 0.03 & na & na & - \\
\hline Cotinine & Nicotine metabolite & 62005 & $486-56-6$ & 0.019 & na & na & - \\
\hline Dehydronifedipine & A ntianginal metabolite & 62004 & $67035-22-7$ & 0.04 & na & na & - \\
\hline Diltiazem & A ntianginal; antihypertensive & 62008 & 42399-41-7 & 0.04 & na & na & $-{ }^{2}$ \\
\hline 1,7-Dimethylxanthine & Caffeine metabolite & 62030 & $611-59-6$ & 0.06 & na & na & - \\
\hline Diphenydramine & Antihistime & 62796 & $147-25-0$ & 0.02 & na & na & - \\
\hline Warfarin & Anticoagulant & 62024 & $81-81-2$ & 0.05 & na & na & -2 \\
\hline
\end{tabular}

${ }^{1}$ The California Groundwater A mbient M onitoring and A ssessment (GA M A) Program uses more conservative reporting limits for the pharmaceutical compounds than are used by the USGS N ational Water Quality Laboratory (NW QL) (Fram and B elitz, 2011). The method detection limit (M DL) corresponds to the highest long-term method detection limit (LT-M DL) or interim method detection limit (I-M DL) used by the NWQL during the period GA M A samples were analyzed (M ay 2004 through J une 2010). Results reported by the NW QL with concentrations less than their M DL s are reported as non-detections by GA M A. Results for the Santa Barbara study unit for all pharmaceutical compounds on schedule 2080 were less than their respective M DL.

${ }^{2}$ The median matrix-spike recovery was less than 70 percent. Low recoveries may indicate that the compound might not have been detected in some samples if it was present at very low concentrations.

${ }^{3}$ Constituent was measured on more than one schedule. See table $3 \mathrm{C}$ for results with preferred method.

Table 3E. Constituents of special interest, primary uses or sources, comparative benchmarks, and reporting information for Weck Laboratories, Inc., City of Industry, California, analyses.

[The five-digit USGS parameter code is used to uniquely identify a specific constituent or property. Minimum reporting level, benchmark type, and benchmark level as of February 4, 2011. Benchmark type: M aximum contaminant level benchmarks are listed as M CL-US when the M CL-US and M CL-CA are identical, and as M CL-CA when the M CL-CA is lower than the M CL-US or no M CL-US exists. M CL-CA, California Department of Public Health (CDPH) maximum contaminant level; NL-CA, CDPH notification level. Other abbreviations: USGS, U.S. Geological Survey; CA S, Chemical A bstract Service; M RL, minimum reporting level; D, detected in groundwater samples (table 7); $\mu \mathrm{g} / \mathrm{L}$, micrograms per liter; - , not detected; SB, Santa B arbara grid well]

\begin{tabular}{|c|c|c|c|c|c|c|c|}
\hline Constituent & $\begin{array}{l}\text { Primary use } \\
\text { or source }\end{array}$ & $\begin{array}{c}\text { USGS } \\
\text { parameter } \\
\text { code }\end{array}$ & $\begin{array}{c}\text { CAS } \\
\text { Registry } \\
\text { Number }^{\circledR}\end{array}$ & $\begin{array}{c}\text { MRL } \\
(\mu \mathrm{g} / \mathrm{L})\end{array}$ & $\begin{array}{c}\text { Benchmark } \\
\text { type }\end{array}$ & $\begin{array}{c}\text { Benchmark } \\
\text { level } \\
(\mu \mathrm{g} / \mathrm{L})\end{array}$ & Detection \\
\hline Perchlorate & Rocket fuel, fireworks, flares & 63790 & $14797-73-0$ & 0.10 & $M C L-C A$ & 6 & D \\
\hline N-Nitrosodimethylamine (NDMA) & Disinfection by-product & 34438 & $62-75-9$ & 0.0020 & $N L-C A$ & 0.010 & -1 \\
\hline
\end{tabular}

\footnotetext{
${ }^{1}$ Sample holding time exceeded for SB-05 and the associated field blank. NDMA might not have been detected in samples if it was present at very low concentrations.
} 
Table 3F. Trace elements, comparative benchmarks, and reporting information for the USGS National Water Quality Laboratory Schedule 1948.

[The five-digit USGS parameter code is used to uniquely identify a specific constituent or property. Method detection level, benchmark type, and benchmark level as of February 4, 2011. Benchmark type: M aximum contaminant level benchmarks are listed as M CL-US when the M CL-US and M CL-CA are identical, and as M CL-CA when the M CL-CA is lower than the M CL-US or no M CL-US exists. Secondary maximum contaminant level benchmarks are listed as SM CL-CA when the SM CL-CA exists, and as the SM CL-US when no SM CL-CA exists. AL-US, U.S. Environmental Protection A gency (USEPA) action level; HAL-US, USEPA lifetime health advisory level; M CL-CA, California Department of Public Health (CDPH) maximum contaminant level; M CL-US, USEPA maximum contaminant level; NL-CA, CDPH notification level; SMCL-CA, CDPH secondary maximum contaminant level. Other abbreviations: USGS, U.S. G eological Survey; CA S, Chemical A bstract Service; LT-M DL, long-term method detection level; D, detected in groundwater samples (table 8); na, not available; $\mu \mathrm{g} / \mathrm{L}$, micrograms per liter; NWIS, USGS N ational Water Information System; N W QL, USGS National Water Quality Laboratory; B QS, USGS Branch of Quality Systems]

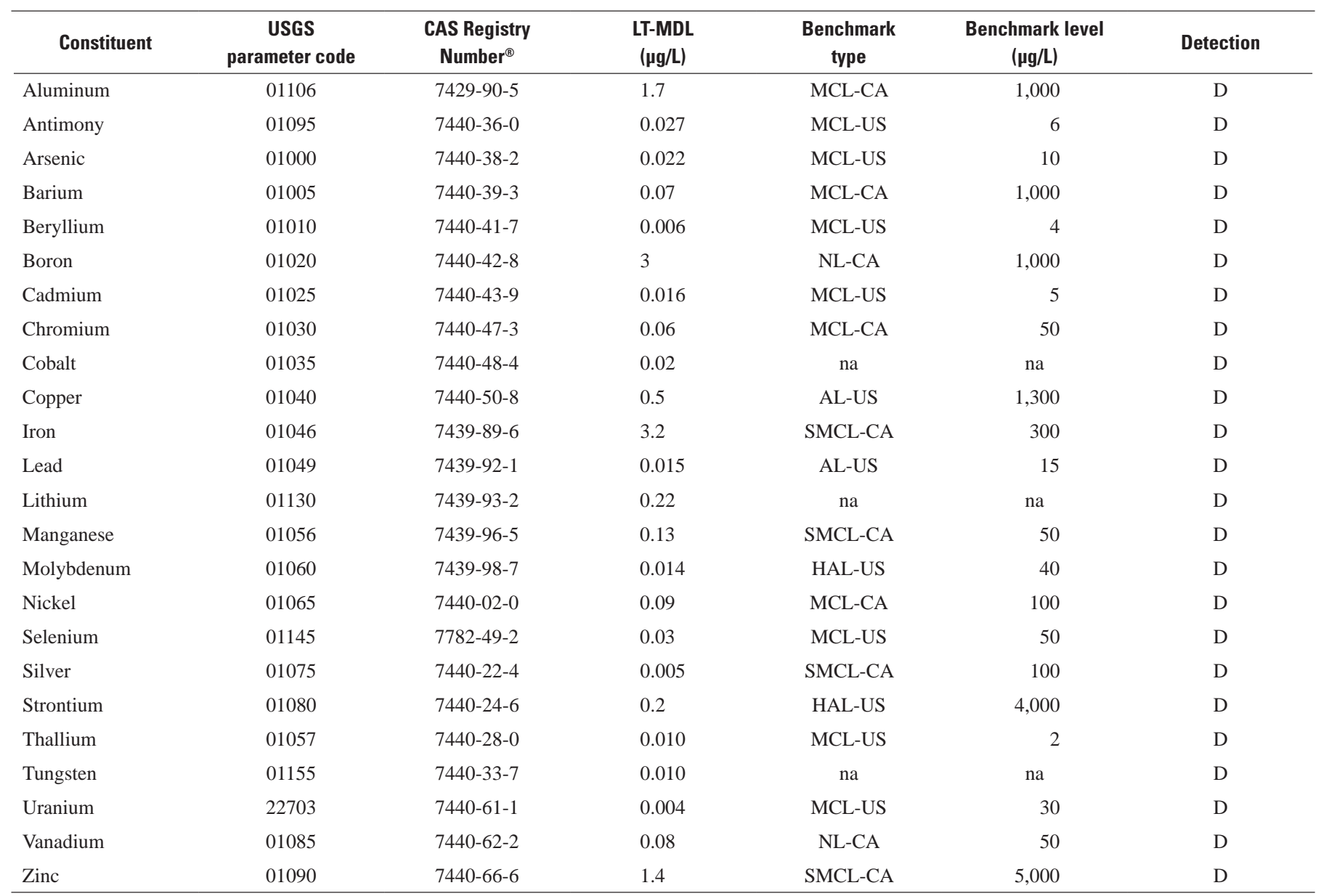

Table 3G. Nutrients, comparative benchmarks, and reporting information for the USGS National Water Quality Laboratory Schedule 2755 .

[The five-digit USGS parameter code is used to uniquely identify a specific constituent or property. Method detection level, benchmark type, and benchmark level as of February 4, 2011. Benchmark type: M aximum contaminant level benchmarks are listed as M CL-US when the M CL-US and M CL-CA are identical, and as M CL-CA when the M CL-CA is lower than the M CL-US or no M CL-US exists. HAL-US, U.S. Environmental Protection A gency (USEPA) lifetime health advisory level; M CL -US, USE PA maximum contaminant level. Other abbreviations: USGS, U.S. G eological Survey; CA S, Chemical A bstract Service; LT-M DL, long-term method detection level; D, detected in groundwater samples (table 9); na, not available; mg/L, milligrams per liter]

\begin{tabular}{|c|c|c|c|c|c|c|}
\hline Constituent & $\begin{array}{c}\text { USGS } \\
\text { parameter code }\end{array}$ & $\begin{array}{c}\text { CAS Registry } \\
\text { Number }^{\circledR}\end{array}$ & $\begin{array}{c}\text { LT-MDL } \\
\text { (mg/L) }\end{array}$ & $\begin{array}{c}\text { Benchmark } \\
\text { type }\end{array}$ & $\begin{array}{c}\text { Benchmark level } \\
\text { (mg/L) }\end{array}$ & Detection \\
\hline A mmonia (as nitrogen) & 00608 & 7664-41-7 & 0.010 & HAL-US & 124.7 & D \\
\hline Nitrate plus nitrite (as nitrogen) & 00631 & na & 0.02 & MCL-US & 10 & D \\
\hline Nitrite (as nitrogen) & 00613 & $14797-65-0$ & 0.0010 & MCL-US & 1 & D \\
\hline Total nitrogen (ammonia, nitrite, nitrate, organic nitrogen) & 62854 & $17778-88-0$ & 0.05 & na & na & D \\
\hline Phosphate, orthophosphate (as phosphorus) & 00671 & $14265-44-2$ & 0.004 & na & na & D \\
\hline
\end{tabular}

${ }^{1}$ The HAL-US is $30 \mathrm{mg} / \mathrm{L}$ "as ammonia." To facilitate comparson to the analytical results, we have converted and reported this HAL-US as $24.7 \mathrm{mg} / \mathrm{L}$ "as nitrogen." 
Table 3H. Major and minor ions, silica, total dissolved solids (TDS), and alkalinity, comparative benchmarks, and reporting information for the USGS National Water Quality Laboratory Schedule 1948.

[The five-digit USGS parameter code is used to uniquely identify a specific constituent or property. Method detection level, benchmark type, and benchmark level as of February 4, 2011. Benchmark type: M aximum contaminant level benchmarks are listed as M CL-US when the M CL-US and M CL-CA are identical, and as M CL-CA when the MCL-CA is lower than the M CL-US or no M CL-US exists. Secondary maximum contaminant level benchmarks are listed as SM CL-CA when the SM CL-CA exists, and as the SM CL-US when no SM CL-CA exists. M CL-CA, California D epartment of Public Health (CDPH) maximum contaminant level; SM CL-CA, CDPH secondary maximum contaminant level. Other abbreviations: USGS, U.S. Geological Survey; CA S, Chemical A bstract Service; LT-M DL, long-term method detection level; M RL, minimum reporting level; D, detected in groundwater samples (table 10); na, not available; $\mathrm{mg} / \mathrm{L}$, milligrams per liter]

\begin{tabular}{|c|c|c|c|c|c|c|}
\hline Constituent & $\begin{array}{c}\text { USGS } \\
\text { parameter } \\
\text { code }\end{array}$ & $\begin{array}{c}\text { CAS } \\
\text { Registry } \\
\text { Number }^{\circledR}\end{array}$ & $\begin{array}{c}\text { LT-MDL, } \\
\text { MDL, or MRL } \\
\text { (mg/L) }\end{array}$ & $\begin{array}{c}\text { Benchmark } \\
\text { type }\end{array}$ & $\begin{array}{c}\text { Benchmark } \\
\text { level } \\
\text { (mg/L) }\end{array}$ & Detection \\
\hline B romide & 71870 & $24959-67-9$ & 0.010 & na & na & $\mathrm{D}$ \\
\hline Calcium & 00915 & $7440-70-2$ & 0.022 & na & na & D \\
\hline Chloride & 00940 & $16887-00-6$ & 0.06 & SMCL-CA & ${ }^{1} 250(500)$ & D \\
\hline Fluoride & 00950 & $16984-48-8$ & 0.04 & MCL-CA & 2 & D \\
\hline M agnesium & 00925 & $7439-95-4$ & 0.008 & na & na & D \\
\hline Potassium & 00935 & $7440-09-7$ & 0.022 & na & na & D \\
\hline Silica (as $\mathrm{SiO}_{2}$ ) & 00955 & $7631-86-9$ & 0.029 & na & na & D \\
\hline Sodium & 00930 & $7440-23-5$ & 0.06 & na & na & D \\
\hline Sulfate & 00945 & 14808-79-8 & 0.09 & SMCL-CA & ${ }^{1} 250(500)$ & D \\
\hline
\end{tabular}

${ }^{1}$ The recommended SM CL-CA benchmarks for chloride, sulfate, and TDS are listed with the upper SM CL-CA benchmarks in parentheses.

${ }^{2} \mathrm{~L}$ aboratory alkalinity results are presented in table 4.

Table 3I. Arsenic, chromium, and iron species, comparative benchmarks, and reporting information for the USGS Trace Metal Laboratory, Boulder, Colorado, analyses.

[The five-digit USGS parameter code is used to uniquely identify a specific constituent or property. Method detection level, benchmark type, and benchmark level as of February 4, 2011. Benchmark type: M aximum contaminant level benchmarks are listed as M CL-US when the M CL-US and M CL-CA are identical, and as M CL-CA when the MCL-CA is lower than the M CL-US or no M CL-US exists. Secondary maximum contaminant level benchmarks are listed as SM CL-CA when the SM CL-CA exists, and as the SM CL-US when no SM CL-CA exists. M CL-CA, California Department of Public Health (CDPH) maximum contaminant level; SM CL-CA, CDPH secondary maximum contaminant level. Other abbreviations: USGS, U.S. Geological Survey; CA S, Chemical A bstract Service; M DL, method detection limit; na, not available; $\mu \mathrm{g} / \mathrm{L}$, micrograms per liter; $\mathrm{D}$, detected in groundwater samples (table 11)]

\begin{tabular}{|c|c|c|c|c|c|c|}
\hline Constituent & $\begin{array}{c}\text { USGS } \\
\text { parameter code }\end{array}$ & $\begin{array}{c}\text { CAS Registry } \\
\text { Number }^{\circledR}\end{array}$ & $\begin{array}{c}\text { MDL } \\
(\mu \mathrm{g} / \mathrm{L})\end{array}$ & $\begin{array}{c}\text { Benchmark } \\
\text { type }\end{array}$ & $\begin{array}{c}\text { Benchmark level } \\
(\mu \mathrm{g} / \mathrm{L})\end{array}$ & Detection \\
\hline A rsenic (total) & 99033 & $7440-38-2$ & 0.2 & MCL-US & 10 & $D$ \\
\hline Chromium (total) & 01030 & $7440-47-3$ & 0.1 & MCL-CA & 50 & D \\
\hline Chromium (VI) & 01032 & $18540-29-9$ & 0.1 & na & na & D \\
\hline Iron (total) & 01046 & $7439-89-6$ & 2 & $S M C L-C A$ & 300 & D \\
\hline
\end{tabular}


Table 3J. Isotope tracers and radioactive constituents, comparative benchmarks, and reporting information for laboratory analyses.

[The five-digit USGS parameter code is used to uniquely identify a specific constituent or property. Laboratory entity codes in the USGS National Water Information System (NWIS) for laboratories other than the USGS N ational Water Q uality Laboratory (NW QL) are given in parentheses after the laboratory names. Stable isotope ratios are reported in the standard delta notation $(\delta)$, the ratio of a heavier isotope to more common lighter isotope of that element, relative to a standard reference material. M ethod uncertainties for the isotope tracers are 2-sigmas; method uncertainties for radioactive constituents are 1-sigma. B enchmark type and benchmark value as of February 4, 2011. Benchmark type: M aximum contaminant level benchmarks are listed as M CL -US when the MCL-US and M CL-CA are identical, and as M CL-CA when the M CL-CA is lower than the M CL-US or no M CL-US exists. M CL-US, USEPA maximum contaminant level; M CL-CA, California Department of Public Health (CDPH) maximum contaminant level. Elements: $\mathrm{H}$, hydrogen; $\mathrm{O}$, oxygen; $B$, boron; Sr, strontium; C, carbon. Reporting units: pCi/L, picocuries per liter; pmc, percent modern carbon. Other abbreviations: USGS, U.S. Geological Survey; CA S, Chemical A bstract Service; na, not available; D, detected in groundwater samples (tables 12, 13A, and 13B); CSU, combined standard uncertainty]

\begin{tabular}{|c|c|c|c|c|c|c|c|}
\hline Constituent & $\begin{array}{c}\text { USGS } \\
\text { parameter code }\end{array}$ & $\begin{array}{c}\text { CAS } \\
\text { number }\end{array}$ & $\begin{array}{c}\text { Method } \\
\text { uncertainty }\end{array}$ & $\begin{array}{l}\text { Reporting } \\
\text { units }\end{array}$ & Benchmark type & $\begin{array}{l}\text { Benchmark level } \\
\text { (pCi/L) }\end{array}$ & Detection \\
\hline \multicolumn{8}{|c|}{ Isotope tracers } \\
\hline$\delta^{18} 0$ in water ${ }^{1}$ & 82085 & na & 0.20 & per mil & na & na & D \\
\hline$\delta^{11} \mathrm{~B}$ in water ${ }^{2}$ & 62648 & na & 2 & per mil & na & na & na \\
\hline Strontium isotope ratio $\left({ }^{87} \mathrm{Sr} /{ }^{86} \mathrm{Sr}\right){ }^{2}$ & 75978 & na & 0.0000 & atom ratio & na & na & na \\
\hline \multicolumn{8}{|c|}{ Radioactive constituents } \\
\hline Carbon-14 ${ }^{3}$ & 49933 & $14762-75-5$ & CSU & $\mathrm{pmc}$ & na & na & D \\
\hline Tritium ${ }^{4}$ & 07000 & $10028-17-8$ & CSU & $\mathrm{pCi} / \mathrm{L}$ & $\mathrm{MCL}-\mathrm{CA}$ & 20,000 & D \\
\hline Radon-222 5 & 82303 & $14859-67-7$ & CSU & $\mathrm{pCi} / \mathrm{L}$ & Proposed M CL-US & 4,000 & D \\
\hline
\end{tabular}

${ }^{1}$ USGS Stable Isotope L aboratory, Reston, Virginia (USGSSIVA).

2 USGS NRP M etals I sotope Research Laboratory, M enlo Park, California (USGSM ICA).

${ }^{3}$ Woods Hole Oceanographic Institution, National Ocean Sciences A ccelerator M ass Spectrometry Facility (N OSA M S), Woods Hole, M assachusetts (MA-WHAMS).

${ }^{4}$ USGS Stable Isotope and Tritium L aboratory, M enlo Park, California (USGSH3CA).

${ }^{5}$ USGS N ational Water Quality Laboratory (USGSNWQL).

${ }^{6}$ Eberline A nalytical Services, Richmond, California (CA-EBERL).

Table 3K. Dissolved gases and isotope tracers, comparison benchmarks, and reporting information for Lawrence Livermore National Laboratory.

[The five-digit USGS parameter code is used to uniquely identify a specific constituent or property. Benchmark type and benchmark values as of February 4 , 2011. Benchmark type: M aximum contaminant level benchmarks are listed as M CL-US when the M CL-US and M CL-CA are identical, and as M CL-CA when the M CL-CA is lower than the M CL-US or no M CL-US exists. M CL-US, USEPA maximum contaminant level; M CL-CA, California Department of Public Health (CDPH) maximum contaminant L evel. R eporting units: $\mathrm{cm}^{3} \mathrm{STP} / \mathrm{g}$, cubic centimeters of gas at standard temperature and pressure per gram of water; pCi/L, picocuries per liter. Other abbreviations: USGS, U.S. Geological Survey; CA S, Chemical A bstract Service; na, not available]






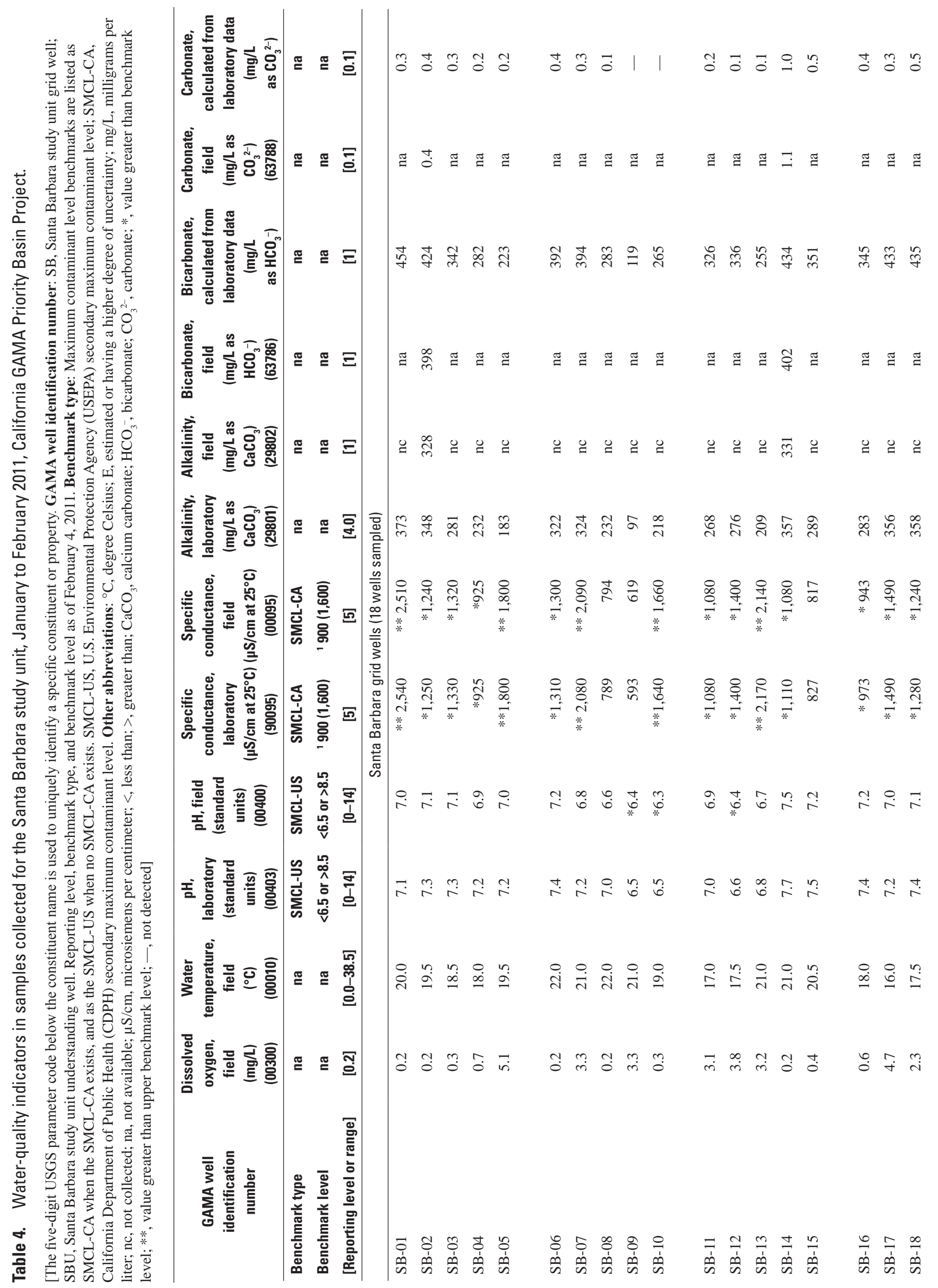


号

$\circ$ के ह का

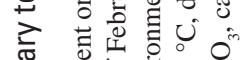

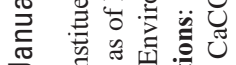

त हैं एं

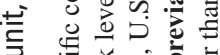

ते हू v

$\approx$

¿

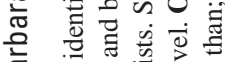

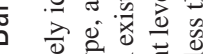

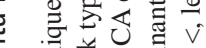

峦

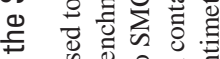

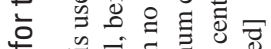

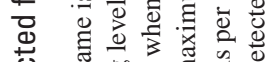

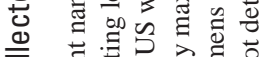

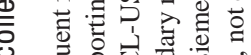

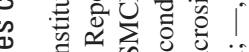

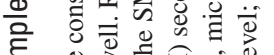

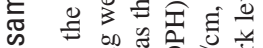

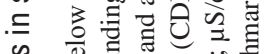

के की

. 잉

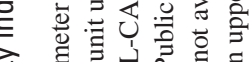

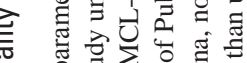

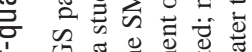

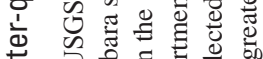

皮

:

•

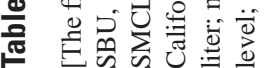

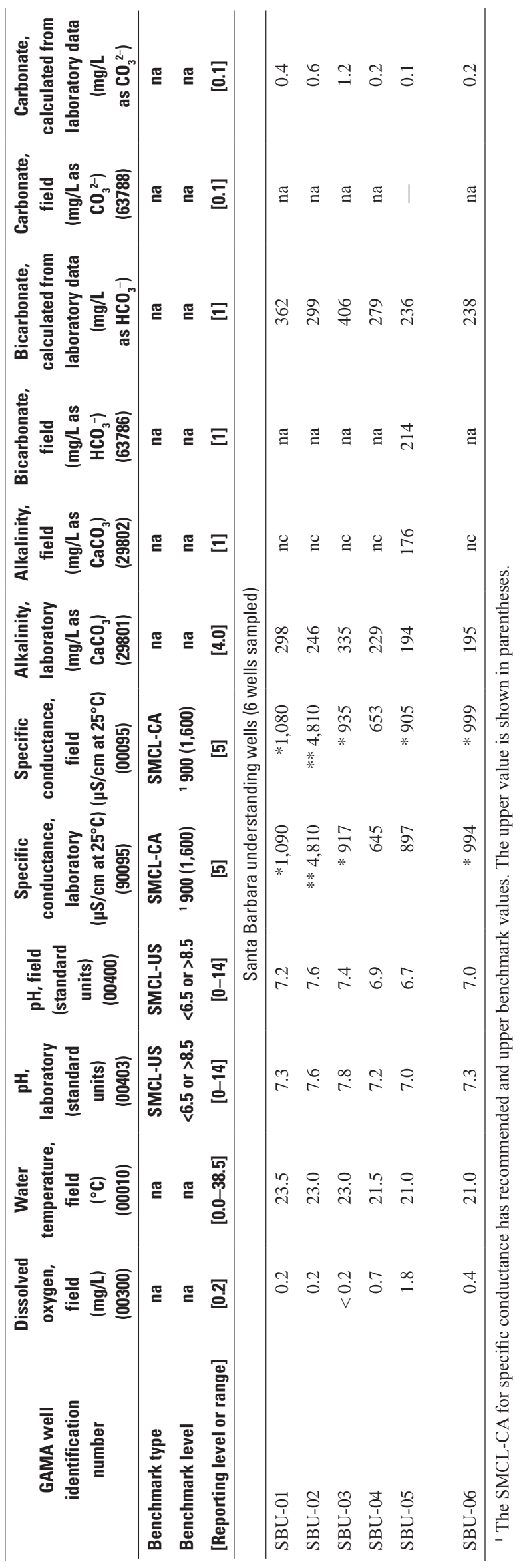



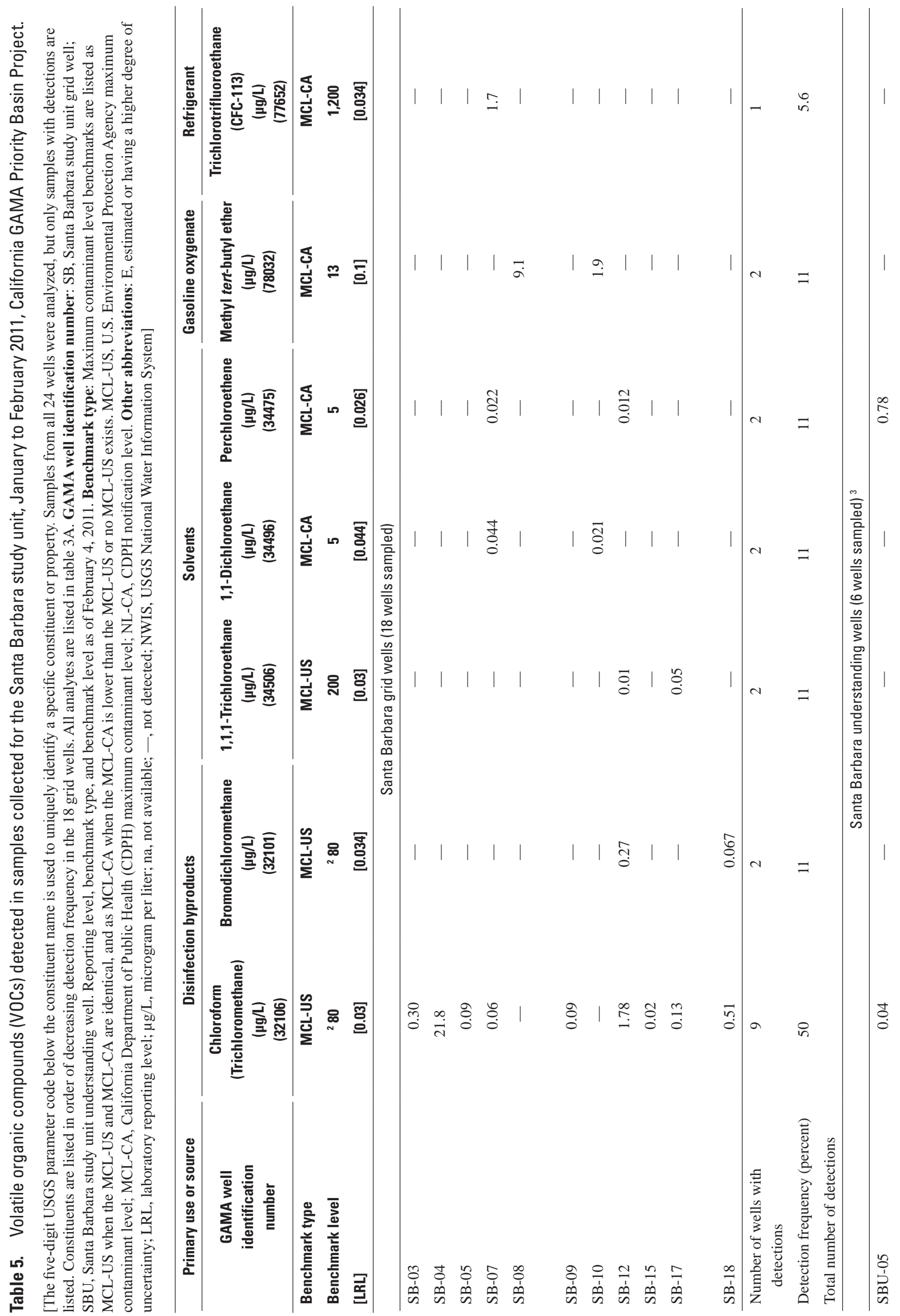


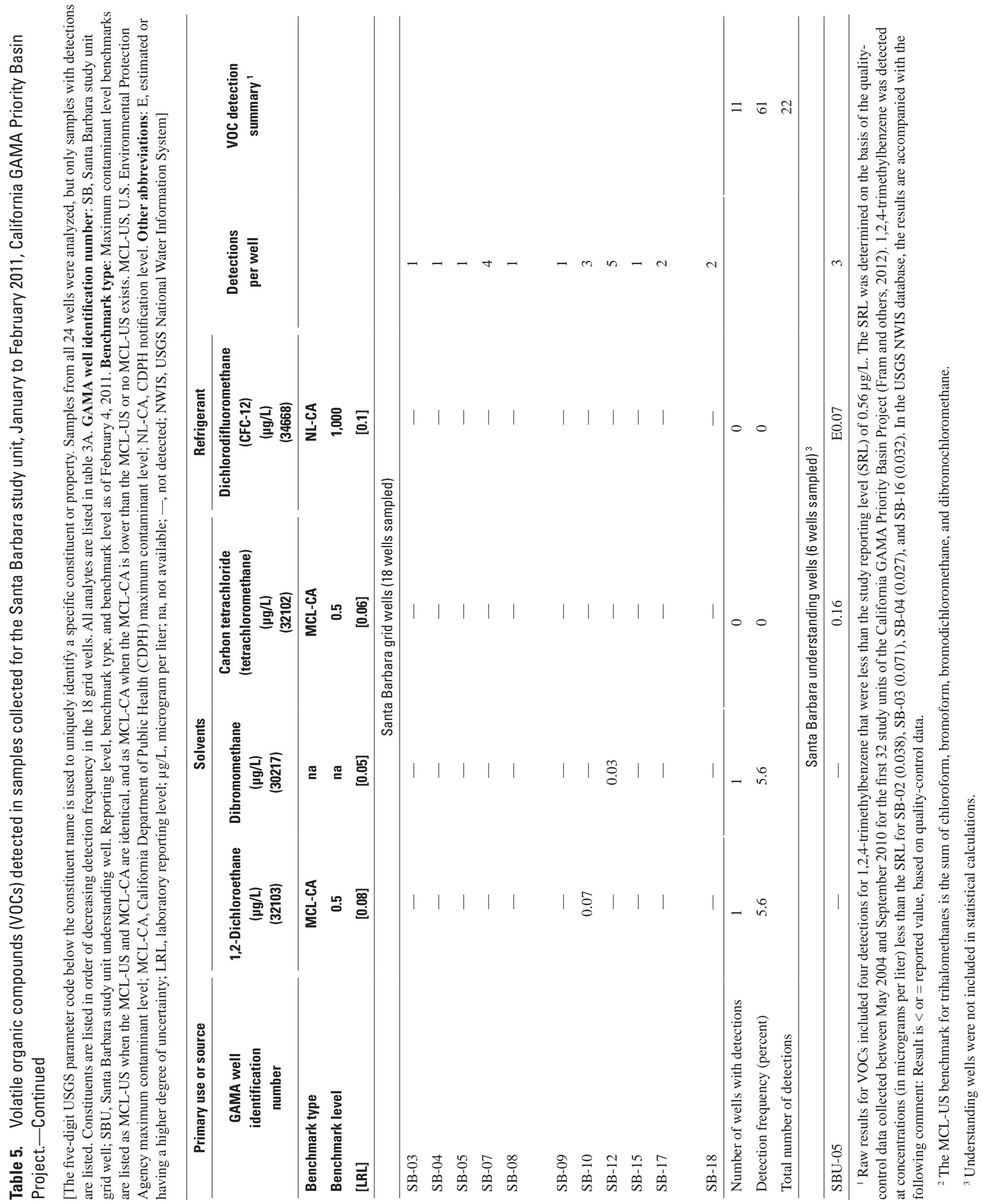


Table 6. Pesticides and pesticide degradates detected in samples collected for the Santa Barbara study unit, January to February 2011, California GAMA Priority Basin Project.

[The five-digit U.S. Geological Survey (USGS) parameter code below the constituent name is used to uniquely identify a specific constituent or property. Samples from 24 wells were analyzed, but only samples with detections are listed. All analytes are listed in table 3B. GAMA well identification number: SB, Santa B arbara study unit grid well. L aboratory reporting level, benchmark type, and benchmark level as of February 4, 2011. Benchmark type: $M$ aximum contaminant level benchmarks are listed as M CL -US when the MCL-US and MCL-CA are identical, and as MCL-CA when the MCL-CA is lower than the MCL-US or no M CL-US exists. MCL-CA, California Department of Public Health (CDPH) maximum contaminant level; M CL-US, U.S. Environmental Protection A gency maximum contaminant level. Other abbreviations: $E$, estimated or having a higher degree of uncertainty; $L R L$, laboratory reporting level; $\mu \mathrm{g} / \mathrm{L}$, micrograms per liter]

\begin{tabular}{|c|c|c|c|}
\hline Primary use or source & Herbicide & \multirow{5}{*}{$\begin{array}{c}\text { Pesticide } \\
\text { detections } \\
\text { per well }\end{array}$} & \multirow{5}{*}{$\begin{array}{l}\text { Pesticide } \\
\text { detection } \\
\text { summary }\end{array}$} \\
\hline $\begin{array}{c}\text { GAMA well } \\
\text { identification } \\
\text { number }\end{array}$ & $\begin{array}{c}\text { Simazine } \\
(\mu \mathrm{g} / \mathrm{L}) \\
(04035)\end{array}$ & & \\
\hline Benchmark type & MCL-US & & \\
\hline Benchmark level & 4 & & \\
\hline [LRL] & {$[0.006]$} & & \\
\hline \multicolumn{4}{|c|}{ Santa Barbara grid wells ( 18 wells sampled) } \\
\hline SB -04 & E0.005 & 1 & \\
\hline SB-17 & E0.004 & 1 & \\
\hline Number of wells with detections & 2 & & 2 \\
\hline Detection frequency (percent) & 11 & & 11 \\
\hline Total number of detections & & & 2 \\
\hline
\end{tabular}

Table 7. Perchlorate detected in the samples collected for the Santa Barbara study unit, January to February 2011, California GAMA Priority Basin Project.

[The five-digit U.S. Geological Survey (USGS) parameter code below the constituent name is used to uniquely identify a specific constituent or property. Information about the constituent is given in table $3 \mathrm{E}$. Samples from all 24 wells were analyzed for perchlorate, but only samples with detections are listed. GAMA well identification number: SB, Santa B arbara study unit grid well; SBU, Santa B arbara study unit understanding well. M inimum reporting level, benchmark type, and benchmark level as of February 4, 2011. Benchmark type: M aximum contaminant level benchmarks are listed as MCL-US when the MCL-US and MCL-CA are identical, and as $M C L-C A$ when the M CL-CA is lower than the MCL-US or no M CL-US exists. M CL-CA, California Department of Public Health (CDPH) maximum contaminant level. Other abbreviations: $M R L$, minimum reporting level; $\mu \mathrm{g} / \mathrm{L}$, microgram per liter]

\begin{tabular}{|c|c|}
\hline $\begin{array}{c}\text { GAMA well } \\
\text { identification } \\
\text { number }\end{array}$ & $\begin{array}{c}\text { Perchlorate } \\
(\mu \mathrm{g} / \mathrm{L}) \\
(63790)\end{array}$ \\
\hline Benchmark type & MCL-CA \\
\hline Benchmark level & 6 \\
\hline [MRL] & {$[0.10]$} \\
\hline \multicolumn{2}{|c|}{ Santa Barbara grid wells (18 wells sampled) } \\
\hline SB-05 & 3.90 \\
\hline SB-07 & 1.65 \\
\hline SB -08 & 0.34 \\
\hline SB -09 & 1.09 \\
\hline SB -10 & 1.03 \\
\hline SB-11 & 0.54 \\
\hline SB-12 & 0.88 \\
\hline SB-13 & 2.18 \\
\hline SB -15 & 1.32 \\
\hline SB -16 & 2.54 \\
\hline SB -17 & 0.57 \\
\hline SB-18 & 0.90 \\
\hline Number of wells with detections & 12 \\
\hline Detection frequency (percent) & 67 \\
\hline \multicolumn{2}{|c|}{ Santa Barbara understanding wells (6 wells sampled) } \\
\hline SBU -05 & 1.43 \\
\hline SBU-06 & 0.24 \\
\hline
\end{tabular}


政

उ- 0 व

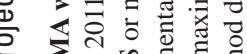

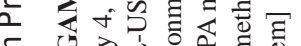

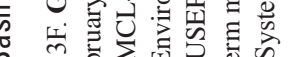

ते एँ

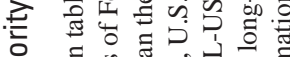

․ㅡㄹ

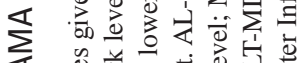

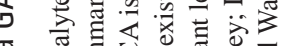

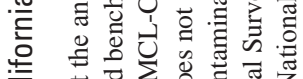

उ

Е 元 \&

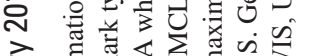

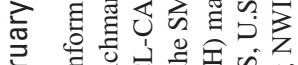

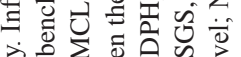

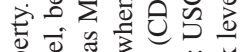

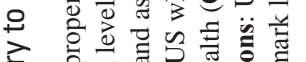

文

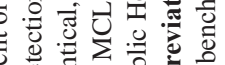

.

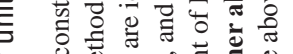

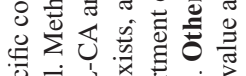

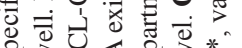

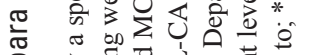

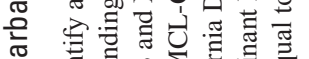

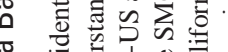

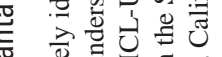

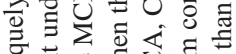

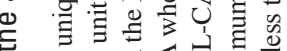

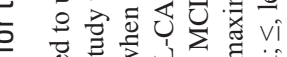

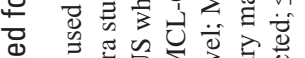

屯. 万ै

言 严

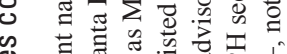

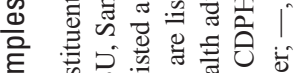

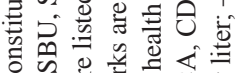

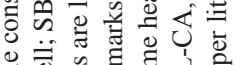

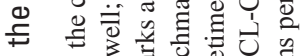

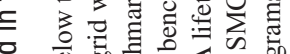

व क

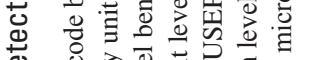

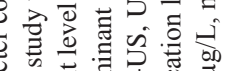

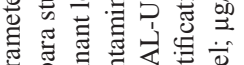

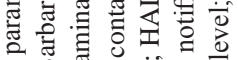

की

Ð

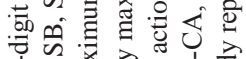

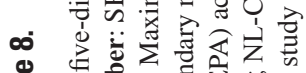

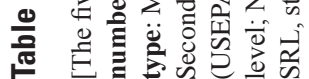

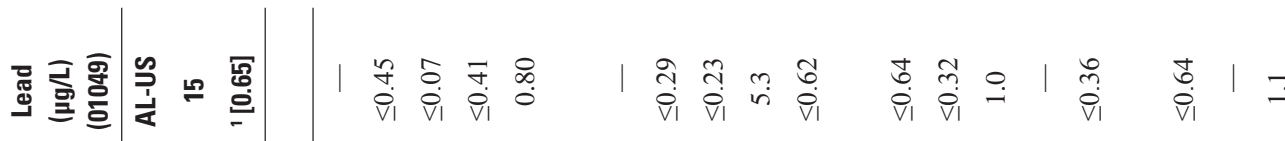

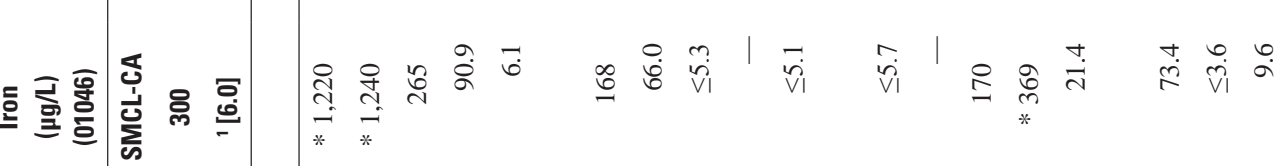

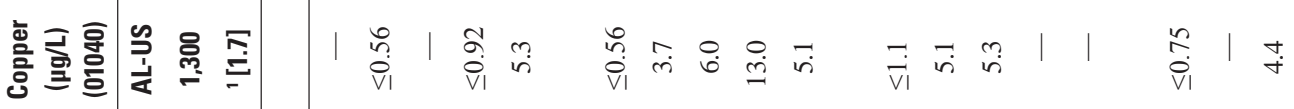

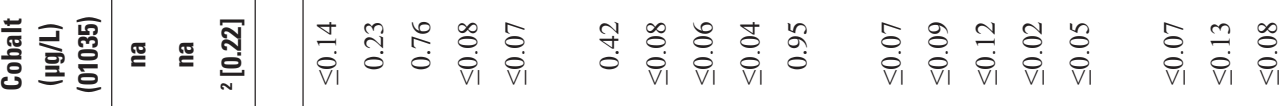

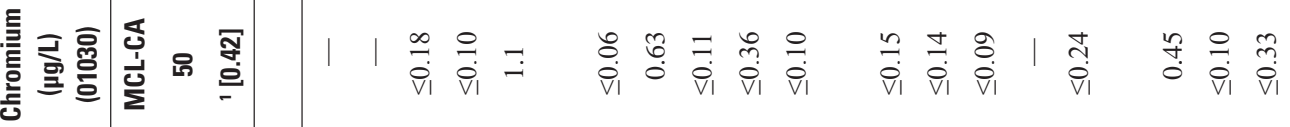

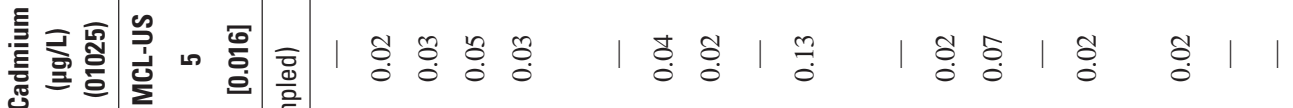

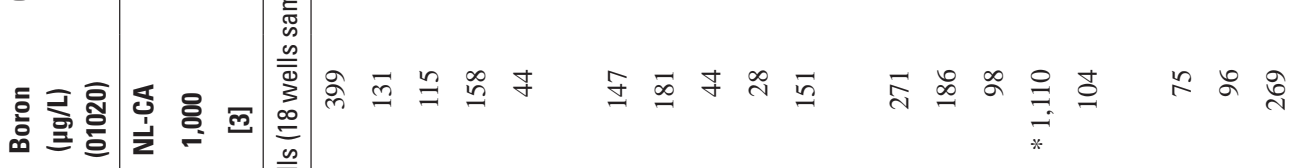

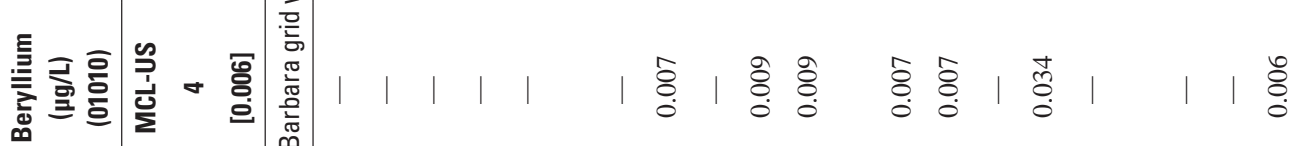

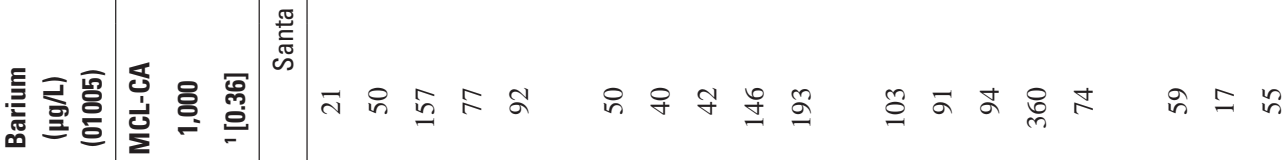

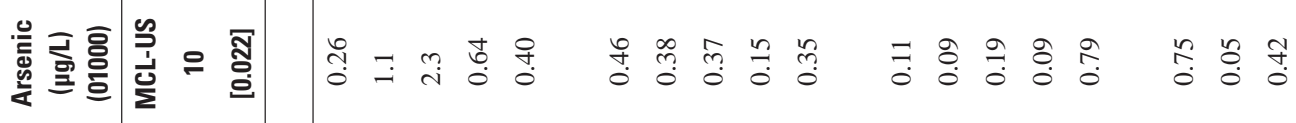

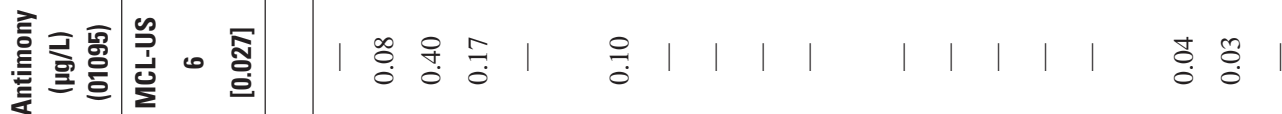

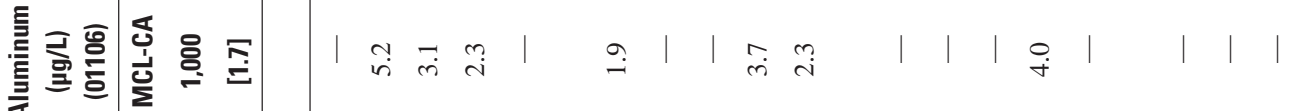

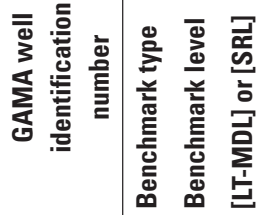

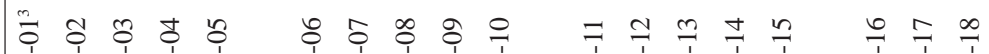

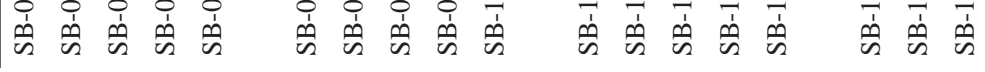




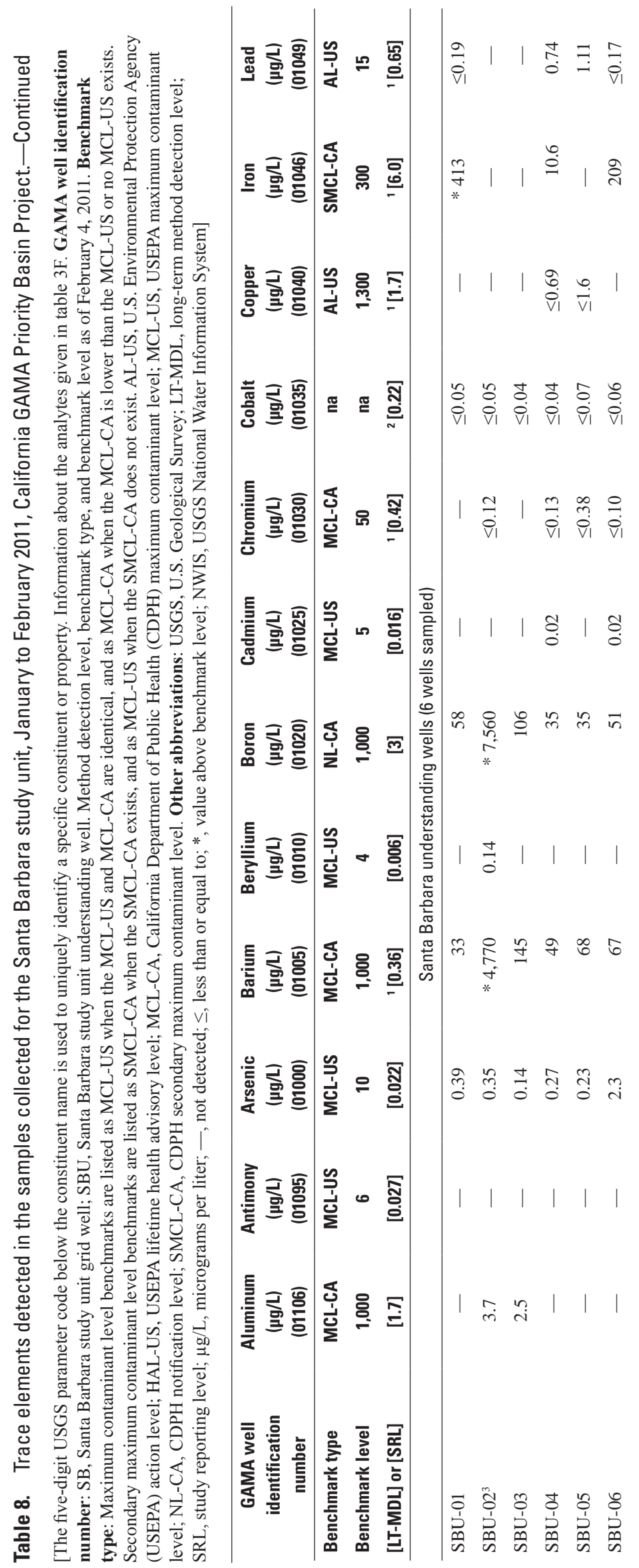




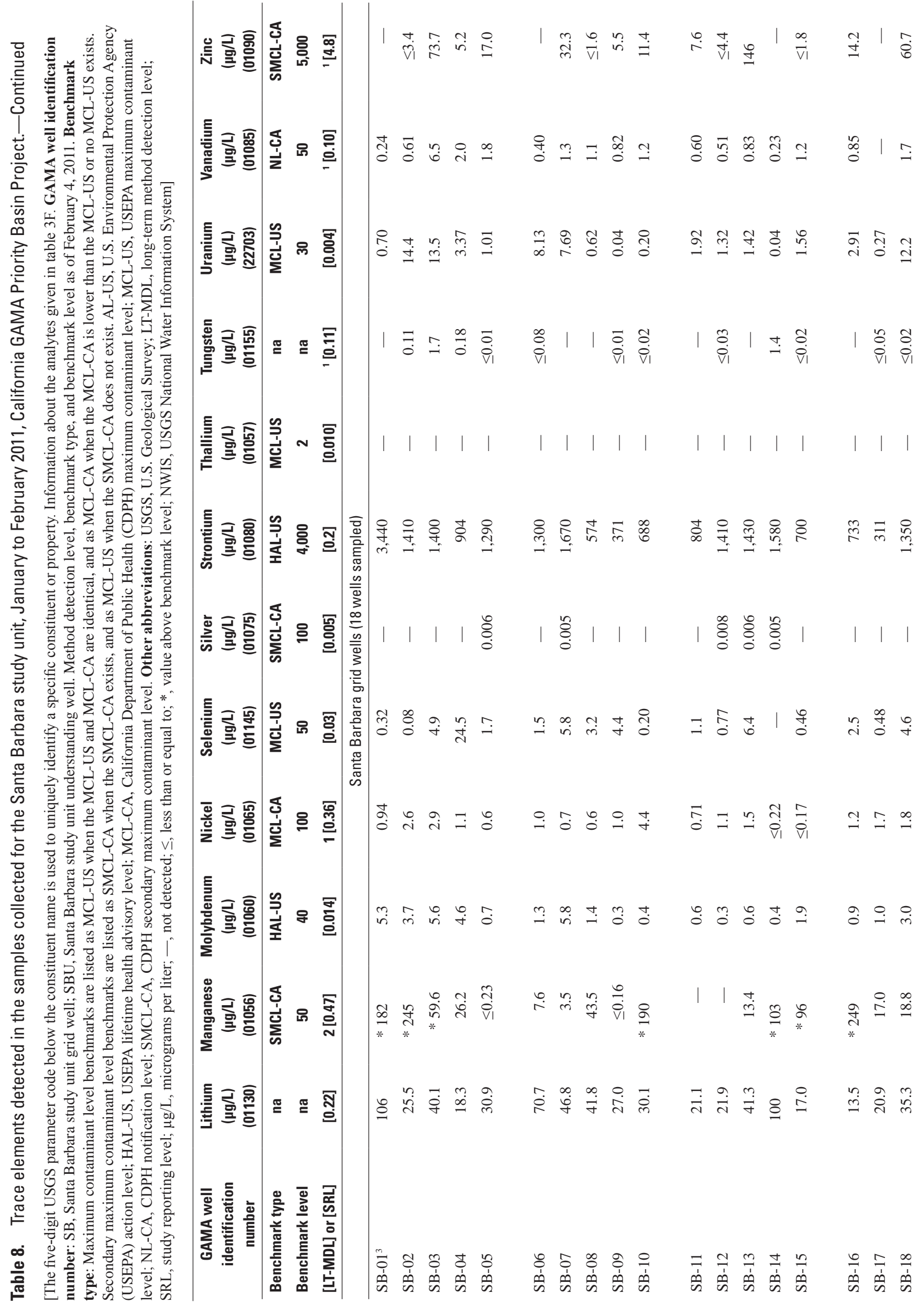




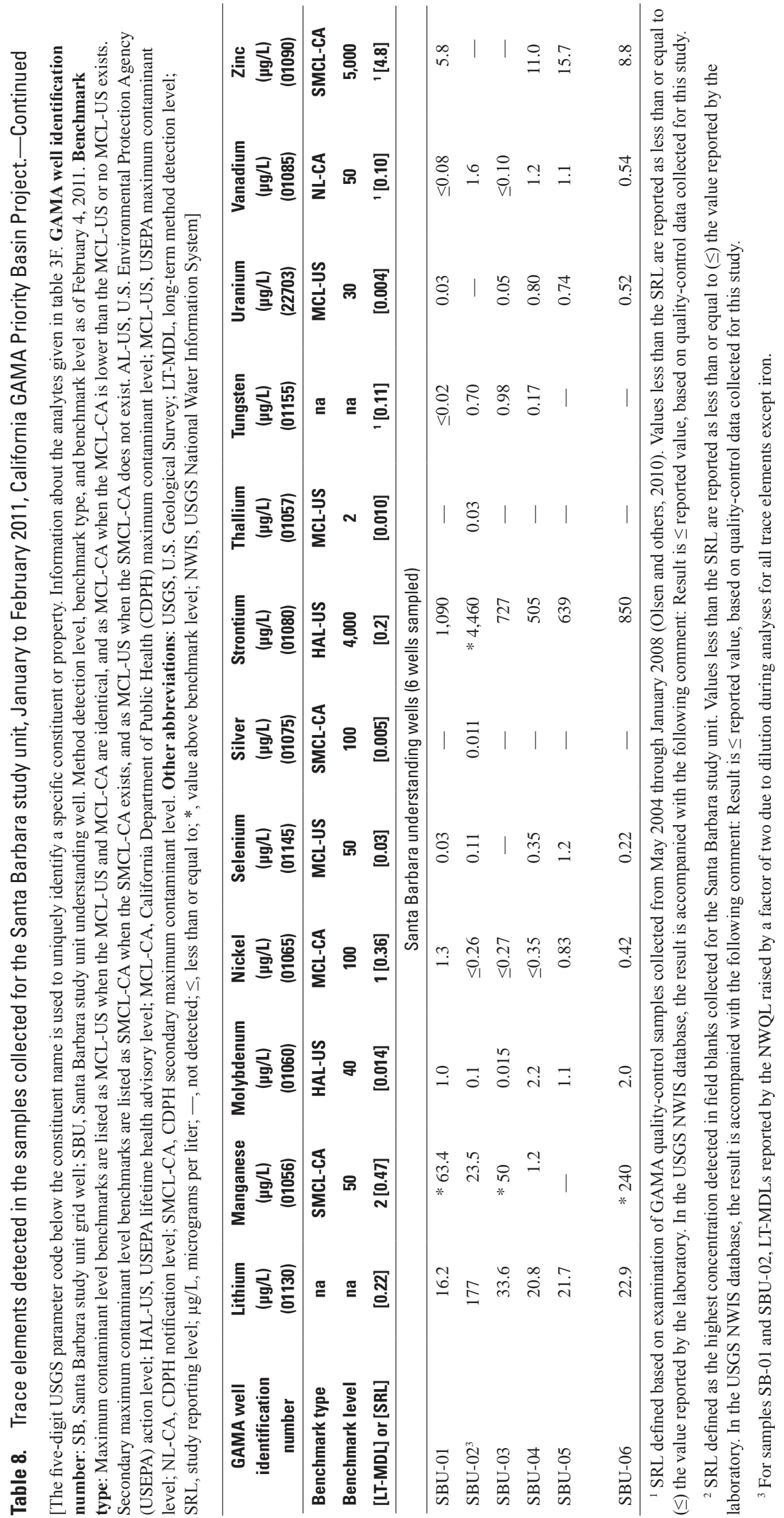


Table 9. Nutrients detected in samples collected for the Santa Barbara study unit, January to February 2011, California GAMA Priority Basin Project.

[The five-digit U.S. Geological Survey parameter code below the constituent name is used to uniquely identify a specific constituent or property. Information about the analytes given in table 3G. GAMA well identification number: SB, Santa B arbara study unit grid well; SBU, Santa B arbara study unit understanding well. L ong-term method detection level, benchmark type, and benchmark level as of February 4, 2011. Benchmark type: M aximum contaminant level benchmarks are listed as M CL-US when the M CL-US and M CL-CA are identical, and as M CL-CA when the M CL-CA is lower than the M CL-US or no M CL-US exists. HAL-US, U.S. Environmental Protection A gency (USEPA) lifetime health advisory level; M CL-US, USEPA maximum contaminant level. Other abbreviations: LT-M DL, long-term method detection level; SRL, study unit reporting level; mg/L, milligrams per liter; na, not available; - , not detected]

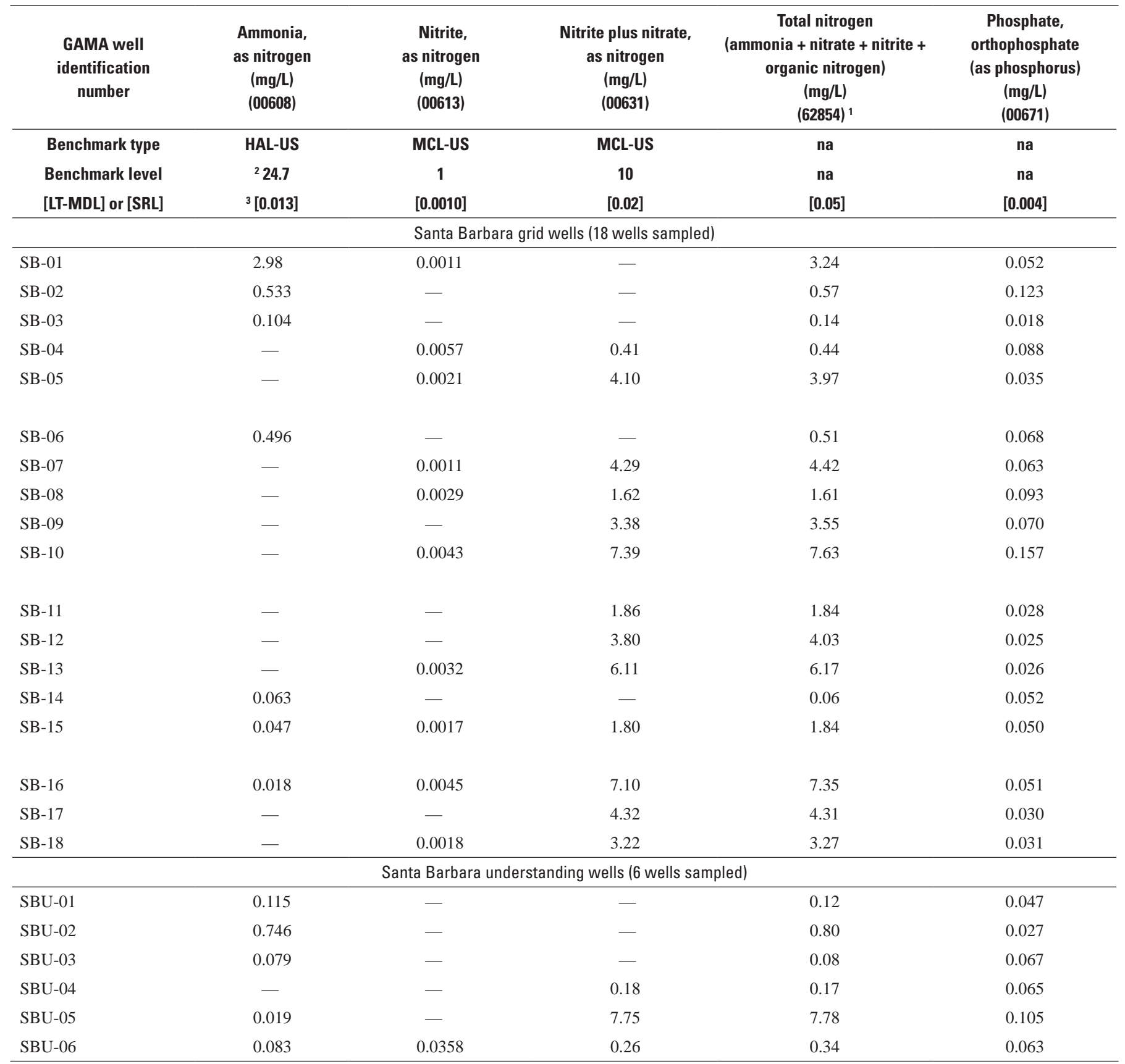

${ }^{1} U$ sing the raw results, total nitrogen concentration was compared with the sum of ammonia concentration and nitrite plus nitrate concentration: for total nitrate concentration greater than $0.25 \mathrm{mg} / \mathrm{L}$ ( 5 times LT-M DL), relative standard deviation less than 10 percent indicates acceptable results; for total nitrate concentration less than or equal to $0.25 \mathrm{mg} / \mathrm{L}$, standard deviation less than $0.025 \mathrm{mg} / \mathrm{L}(1 / 2 \mathrm{LT}-\mathrm{M} \mathrm{DL})$ indicates acceptable results. A II nutrient results for the Santa B arbara study unit met the acceptablility criteria.

${ }^{2}$ The HAL -US is $30 \mathrm{mg} / \mathrm{L}$ "as ammonia." To facilitate comparison to the analytical results, we have converted and reported this HA L-US as $24.7 \mathrm{mg} / \mathrm{L}$ "as nitrogen."

${ }^{3}$ SRL defined for ammonia as the highest concentration detected in field blanks collected for the Santa Barbara study unit. All detections of ammonia reported by the laboratory were greater than the SRL. 
Table 10. Major and minor ions, silica, and total dissolved solids (TDS) detected in samples collected for the Santa Barbara study unit, January to February 2011, California GAMA Priority Basin Project.

[The five-digit U.S. Geological Survey parameter code below the constituent name is used to uniquely identify a specific constituent or property. Information about the analytes given in table 3H. GAMA well identification number: SB, Santa B arbara study unit grid well; SBU, Santa B arbara study unit understanding well. Laboratory reporting level, benchmark type, and benchmark level as of February 4, 2011. Benchmark type: M aximum contaminant level benchmarks are listed as M CL-US when the M CL-US and M CL-CA are identical, and as M CL-CA when the M CL-CA is lower than the M CL-US or no M CL-US exists. Secondary maximum contaminant level benchmarks are listed as SM CL-CA when the SM CL-CA exists, and as SM CL-US when the SM CL-CA does not exist. M CL-CA, California Department of Public Health (CDPH) maximum contaminant level; SM CL-CA, CD PH secondary maximum contaminant level. Other abbreviations: LT-M DL, long-term method detection level; M RL, minimum reporting level; mg/L, milligrams per liter; $\mathrm{SiO}_{2}$, silicon dioxide; - , not detected; *, value above benchmark level; **, value above upper benchmark level]

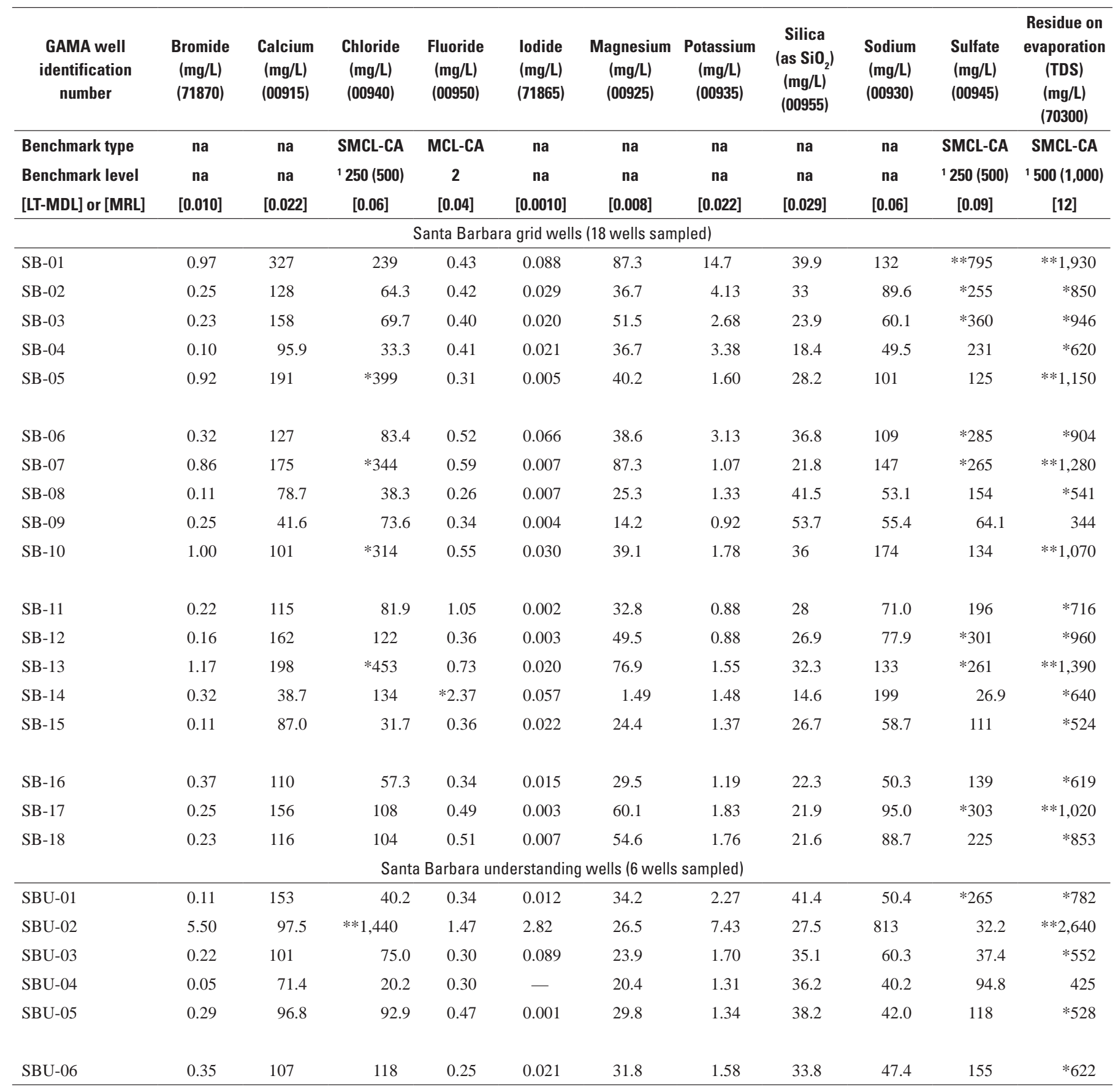

${ }^{1}$ The SM CL-CA for chloride, sulfate, and TDS have recommended and upper benchmark values. The upper value is shown in parentheses. 
Table 11. Arsenic, chromium, and iron species detected in samples collected for the Santa Barbara study unit, January to February 2011, California GAMA Priority Basin Project.

[D ata in this table analyzed at U.S. Geological Survey (USGS) Trace M etals L aboratory using research methods. Information about the analytes given in table 3I. The five-digit USGS parameter code below the constituent name is used to uniquely identify a specific constituent or property. GAM A well identification number: SB, Santa B arbara study unit grid well; SBU, Santa B arbara study unit understanding well. M ethod detection level, benchmark type, and benchmark level as of February 4, 2011. Benchmark type: M aximum contaminant level benchmarks are listed as M CL-US when the M CL-US and MCL-CA are identical, and as M CL-CA when the M CL-CA is lower than the M CL-US or no M CL-US exists. Secondary maximum contaminant level benchmarks are listed as SM CL-CA when the SM CL-CA exists, and as the SM CL-US when the SM CL-CA does not exist. M CL-US, U.S. Environmental Protection A gency (USEPA) maximum contaminant level; M CL -CA, California Department of Public Health (CDPH) maximum contaminant level;

SM CL-CA , CDPH secondary maximum contaminant level. Other abbreviations: M DL, method detection limit; na, not available; $\mu \mathrm{g} / \mathrm{L}$, micrograms per liter; - , not detected; *, greater than the benchmark level]

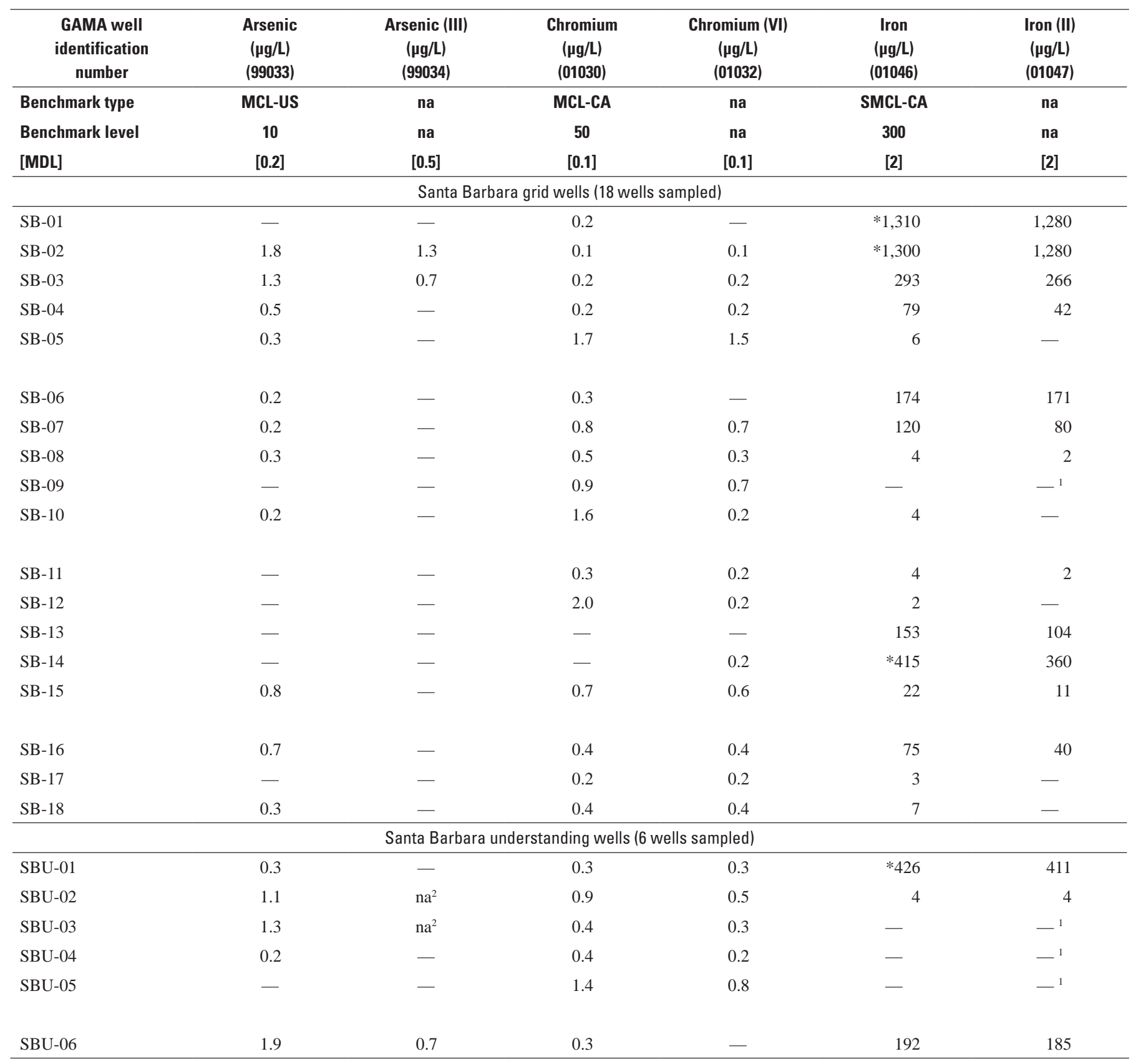

\footnotetext{
${ }^{1}$ Iron (II) is not measured if iron (total) is a non-detection.
}

${ }^{2}$ Values censored by the laboratory due to suspected positive interference during analysis. 
Table 12. Results for analyses of stable isotope ratios, tritium activity, and carbon-14 abundance detected in samples collected for the Santa Barbara study unit, January to February 2011, California GAMA Priority Basin Project.

[The five-digit U.S. Geological Survey parameter code below the constituent name is used to uniquely identify a specific constituent or property. Information about the analytes given in table 3J. Stable isotope ratios are reported in the standard delta notation $(\delta)$, the ratio of a heavier isotope to more common lighter isotope of that element, relative to a standard reference material. Measured values of tritium less than the sample-specific critical level (ssL $\mathrm{s}_{\mathrm{c}}$ ) are reported as non-detections (- ). GAMA well identification number: SB, Santa Barbara study unit grid well; SBU, Santa B arbara study unit understanding well. B enchmark type and benchmark level as of February 4, 2011. Benchmark type: M aximum contaminant level benchmarks are listed as M CL-US when the MCL-US and M CL-CA are identical, and as M CL-CA when the MCL-CA is lower than the M CL-US or no M CL-US exists. M CL-CA, California Department of Public Health (CDPH) maximum contaminant level. Elements: $\mathrm{H}$, hydrogen; $\mathrm{O}$, oxygen; $\mathrm{C}$, carbon. Other abbreviations: CSU, 1-sigma combined standard uncertainty; \pm , plus or minus; $\mathrm{pCi} / \mathrm{L}$, picocuries per liter; na, not available]

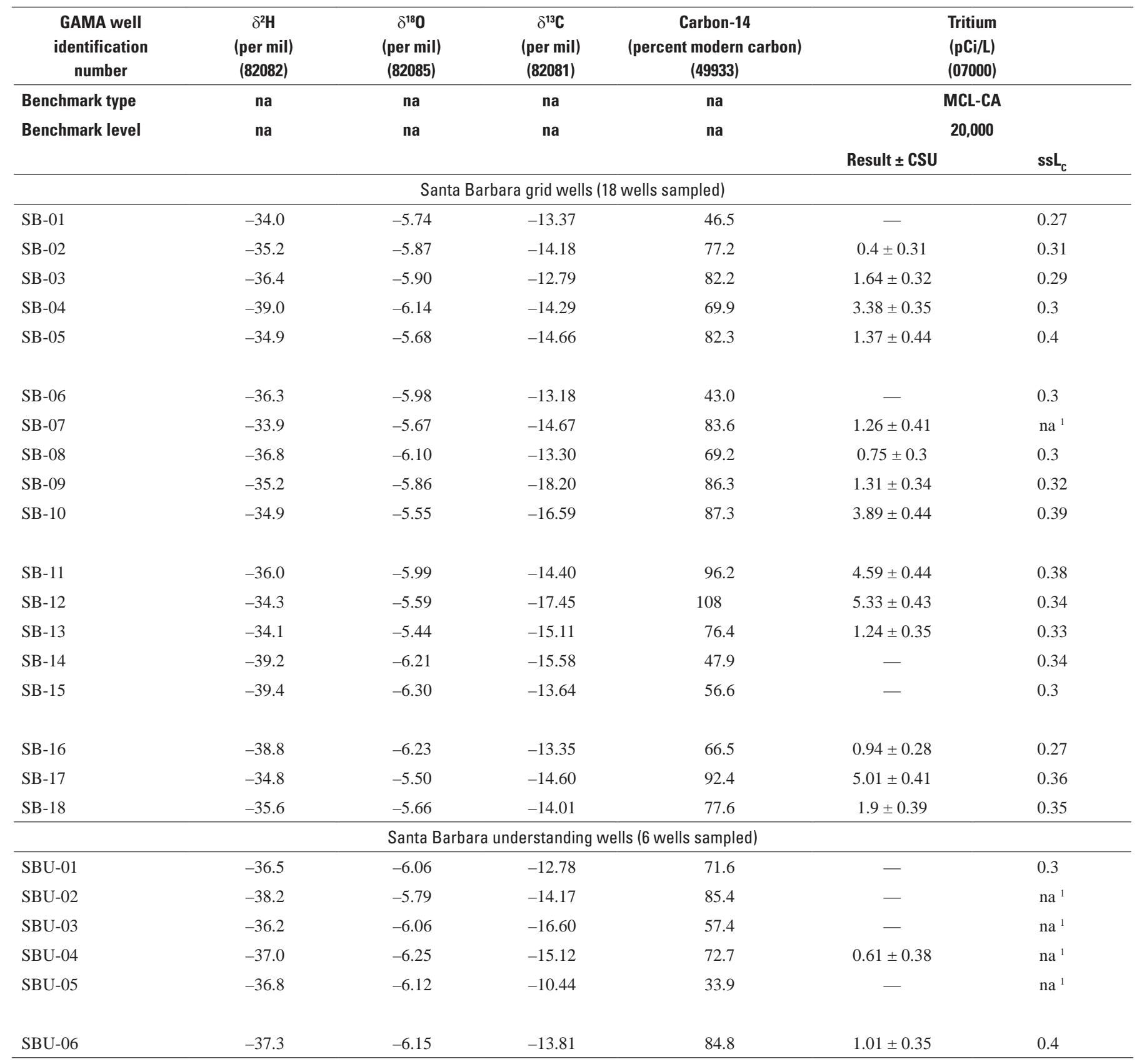

\footnotetext{
${ }^{1}$ Some $s s L_{c} s$ were not reported by the laboratory in time for inclusion in this report. For these results, measured values of tritium less than the 1-sigma combined standard uncertainty (SBU-02: 0.41; SBU -03: 0.41; SBU -05: 0.38) were reported as non-detections.
} 
Table 13A. Radon-222 detected in samples collected for the Santa Barbara study unit, January to February 2011, California GAMA Priority Basin Project.

[The five-digit number in parentheses below the constituent name is the U.S. Geological Survey parameter code used to uniquely identify a specific constituent or property. Samples from 22 wells were analyzed. Information about the analytes are given in table 3 3. The reporting levels for radioactive constituents are given as sample-specific critical levels $\left(\mathrm{ssL}_{c}\right)$. GAMA well identification number: SB, Santa B arbara study unit grid well; SBU, Santa $B$ arbara study unit understanding well. B enchmark type and benchmark level as of February 4, 2011. Benchmark type: M aximum contaminant level benchmarks are listed as M CL-US when the M CL-US and M CL-CA are identical, and as MCL-CA when the MCL-CA is lower than the M CL-US or no M CL-US exists. M CL-US, U.S. Environmental Protection A gency (USEPA) maximum contaminant level. Other abbreviations: CSU, 1-sigma combined standard uncertainty; pCi/L, picocuries per liter; \pm , plus or minus]

\begin{tabular}{|c|c|c|}
\hline $\begin{array}{c}\text { GAMA well } \\
\text { identification } \\
\text { number }\end{array}$ & \multicolumn{2}{|c|}{$\begin{array}{c}\text { Radon-222 } \\
\text { (pCi/L) } \\
(82303)\end{array}$} \\
\hline Benchmark type & \multicolumn{2}{|c|}{ Proposed MCL-US } \\
\hline \multirow[t]{2}{*}{ Benchmark level } & \multicolumn{2}{|c|}{4,000} \\
\hline & Result \pm CSU & $\mathrm{ssL}_{\mathrm{c}}$ \\
\hline \multicolumn{3}{|c|}{ Santa Barbara grid wells ( 16 wells sampled) ${ }^{1}$} \\
\hline SB-01 & $139 \pm 13$ & 12 \\
\hline SB-03 & $840 \pm 49$ & 13 \\
\hline SB-04 & $274 \pm 19$ & 12 \\
\hline SB -05 & $1,150 \pm 66$ & 14 \\
\hline SB-07 & $860 \pm 50$ & 10 \\
\hline SB-08 & $1,070 \pm 60$ & 10 \\
\hline SB -09 & $1,500 \pm 83$ & 12 \\
\hline SB -10 & $760 \pm 44$ & 12 \\
\hline SB-11 & $1,080 \pm 61$ & 11 \\
\hline SB-12 & $1,990 \pm 110$ & 14 \\
\hline SB -13 & $1,460 \pm 82$ & 14 \\
\hline SB-14 & $520 \pm 32$ & 11 \\
\hline SB-15 & $390 \pm 26$ & 14 \\
\hline SB-16 & $330 \pm 22$ & 12 \\
\hline SB-17 & $1,180 \pm 67$ & 14 \\
\hline SB -18 & $660 \pm 39$ & 12 \\
\hline \multicolumn{3}{|c|}{ Santa Barbara understanding wells ( 6 wells sampled) } \\
\hline SBU -01 & $212 \pm 16$ & 12 \\
\hline SBU -02 & $470 \pm 30$ & 14 \\
\hline SBU -03 & $840 \pm 50$ & 14 \\
\hline SBU -04 & $350 \pm 23$ & 12 \\
\hline SBU -05 & $630 \pm 38$ & 12 \\
\hline SBU -06 & $850 \pm 49$ & 12 \\
\hline
\end{tabular}

${ }^{1}$ Sample-collection syringe broke before radon samples from SB-02 and SB-06 could be collected. 
Table 13B. Gross alpha and gross beta radioactivity detected in samples collected for the Santa Barbara study unit, January to February 2011, California GAMA Priority Basin Project.

[The five-digit number in parentheses below the constituent name is the U.S. Geological Survey parameter code used to uniquely identify a specific constituent or property. Information about the analytes given in table 3]. The reference nuclide for measurement of gross al pha radioactivity is thorium-230, and the reference nuclide for measurement of gross beta radioactivity is cesium-137. The reporting levels for radioactive constituents are given as sample-specific critical levels $\left(s s L_{c}\right)$. M easured values less than the $s s L_{c}$ are reported as non-detections $(-)$. GAMA well identification number: $S B$, Santa B arbara study unit grid well; SBU, Santa B arbara study unit understanding well. B enchmark type and benchmark level as of February 4, 2011. Benchmark type: M aximum contaminant level benchmarks are listed as MCL-US when the MCL-US and M CL-CA are identical, and as M CL-CA when the MCL-CA is lower than the M CL-US or no M CL-US exists. M CL-US, U.S. Environmental Protection A gency (USEPA) maximum contaminant level. Other abbreviations: CSU, 1-sigma combined standard uncertainty; $\mathrm{pCi} / \mathrm{L}$, picocuries per liter; \pm , plus or minus]

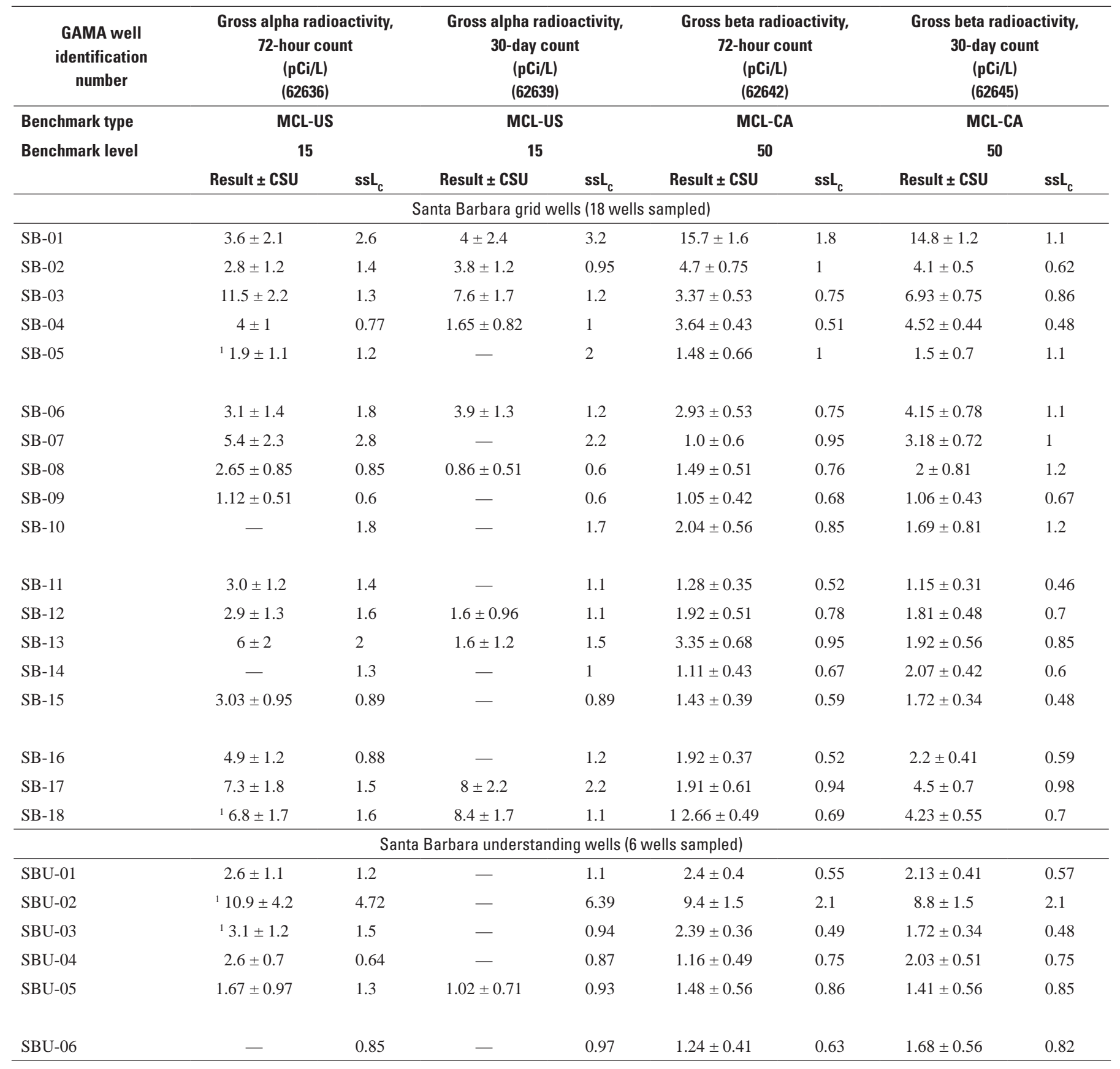

${ }^{1} 72$-hour holding time exceeded by 4 to 5 days from time of sample collection. 


\section{Appendix}

This appendix includes discussions of the methods used to collect and analyze groundwater samples and report the resulting water-quality data. These methods were selected to obtain representative samples of the groundwater from each well and to minimize the potential for contamination of the samples or bias in the data. Procedures used to collect and assess QC data and the results of the QC assessments also are discussed.

In the Santa B arbara study unit, groundwater samples were collected, and QA procedures were implemented by using standard and modified USGS protocols from the NAW QA Program (K oterba and others, 1995), the NFM (U.S. Geological Survey, variously dated), and protocols described by Shelton and others (2001) and Wright and others (2005). The QA plan followed by the NW QL, the primary laboratory used to analyze samples for this study, is described in M aloney (2005) and Pirkey and Glodt (1998).

\section{Sample Collection and Analysis}

Wells were pumped continuously to purge at least three casing volumes of water from the well prior to sampling (Wilde and others, 1999). Wells were sampled using Teflon ${ }^{\circledR}$ tubing with brass and stainless-steel fittings attached to a sampling point (usually a hose-bib fitting) on the well discharge pipe as close to the well head as possible. The sampling point was located upstream from water-storage tanks and upstream from the well-head treatment system (if a system existed). If a chlorinating system was attached to the well, the chlorinator was shut off, when possible, before the well was purged and sampled, in order to clear all chlorine out of the system. The absence of free chlorine was verified by using a $\mathrm{Hach}^{\circledR}$ field test kit. All monitoring wells sampled for the Santa B arbara study unit were artesian wells, and special monitoring-well sampling equipment was not used. A II samples were collected outdoors by connecting a 1- to 3-foot length of Teflon ${ }^{\circledR}$ tubing to the sampling point (L ane and others, 2003). All fittings and lengths of tubing were cleaned between samples (Wilde, 2004).

For the field measurements, groundwater was pumped through a flow-through chamber that was attached to the sampling point and fitted with a multi-probe meter that simultaneously measures the field water-quality indicatorsdissolved oxygen, temperature, $\mathrm{pH}$, and specific conductance. Field measurements were made in accordance with protocols in the NFM (Radtke and others, 2005; Wilde and R adtke, 2005; Lewis, 2006; Wilde, 2006; Wilde and others, 2006). All sensors on the multi-probe meter were calibrated daily. Measured dissolved oxygen, temperature, $\mathrm{pH}$, and specificconductance values were recorded at 5-minute ( $\mathrm{min}$ ) intervals, and when these values remained stable for a minimum of $30 \mathrm{~min}$, samples for laboratory analyses then were collected.
Field measurements and instrument calibrations were recorded by hand on field record sheets and electronically in the Personal Computer Field Form (PCFF) program. A nalytical service requests also were managed by PCFF, whereas analytical service requests for non-NW Q L analysis were entered into laboratory-specific spreadsheets. Information from PCFF was uploaded directly into NWIS at the end of every week of sample collection.

Prior to sample collection, polyethylene sample bottles were pre-rinsed three times using deionized water, and then once with native sample water before sample collection. Samples requiring acidification were acidified to a $\mathrm{pH}$ of between 2 and 1 with the appropriate acids using ampoules of certified, traceable concentrated acids obtained from the NWQL.

Temperature-sensitive samples were stored on ice prior to and during daily shipping to the various laboratories. The non-temperature-sensitive samples for tritium, stable isotopes of hydrogen and oxygen in water, and dissolved noble gases were shipped monthly. Temperature-sensitive or time-sensitive samples for V OCs, pesticides (including polar pesticides) and pesticide degradates, pharmaceutical compounds, perchlorate, NDM A, trace elements, nutrients, major and minor ions, silica, TDS, laboratory al kalinity, radon-222, and gross alpha and gross beta radioactivity were shipped daily whenever possible. Samples to be analyzed for arsenic, chromium, and iron species were shipped weekly. The temperature-sensitive samples for stable isotopes of carbon in dissolved inorganic carbon and carbon-14 abundance were stored on ice, archived in a laboratory refrigerator, and shipped after all of the laboratory al kalinity measurements were received. I sotopes of dissolved boron and strontium in water samples were stored at room temperature in the office until all groundwater samples were collected and results from the trace el ement analyses were obtained; a subset of samples was selected for analyses, based on total boron and strontium concentrations.

Detailed sampling protocols for individual analyses and groups of analytes are described in $\mathrm{K}$ oterba and others (1995), the NFM (Wilde and others, 1999, 2004), and in the references for analytical methods listed in table A 1; only brief descriptions are given here. $\mathrm{VOC}$ samples were collected in three 40-milliliter $(\mathrm{mL})$ sample vials that were purged with three vial volumes of unfiltered groundwater before bottom filling to eliminate atmospheric contamination. One to one (1:1) hydrochloric acid to water $\left(\mathrm{HCl} / \mathrm{H}_{2} \mathrm{O}\right)$ solution was added as a preservative to the $\mathrm{V} O \mathrm{C}$ samples. Each sample to be analyzed for perchlorate was collected in a $125-\mathrm{mL}$ polystyrene bottle and then filtered in two or three $20-\mathrm{mL}$ aliquots of groundwater through a 0.20 -micrometer $(\mu \mathrm{m})$ poresize Corning ${ }^{\circledR}$ syringe-tip disk filter into a sterilized $125-\mathrm{mL}$ bottle. Tritium samples were collected by bottom filling one 1-liter (L) polyethylene bottle and one 1-L glass bottle with unfiltered groundwater, after first overfilling the bottles with three volumes of unfiltered groundwater. Samples for analysis of stable isotopes of hydrogen and oxygen in water were 
collected in a $60-\mathrm{mL}$ clear glass bottle filled with unfiltered groundwater, sealed with a conical cap, and secured with electrical tape to prevent leakage and evaporation.

Samples for analysis of pesticides (including polar pesticides), pesticide degradates, and pharmaceutical compounds were collected in 1-L baked amber glass bottles. These samples were filtered through a $0.7-\mu \mathrm{m}$ nominal poresize glass fiber filter during collection. NDMA samples were collected in $500-\mathrm{mL}$ baked amber glass bottles treated with 0.05 gram of sodium thiosulfate $\left(\mathrm{Na}_{2} \mathrm{~S}_{2} \mathrm{O}_{3}\right)$ as a preservative and were filtered at Weck Laboratories, Inc., prior to analysis.

Groundwater samples for trace el ements, major and minor ions, silica, laboratory alkalinity, and TDS analyses required filling one $250-\mathrm{mL}$ polyethylene bottle with unfiltered groundwater and one $500-\mathrm{mL}$ and one $250-\mathrm{mL}$ polyethylene bottle with filtered groundwater (Wilde and others, 2004). Filtration was done using a $0.45-\mu \mathrm{m}$ poresize PA LL ${ }^{\circledR}$ unvented capsule filter that was pre-rinsed with $2 \mathrm{~L}$ of dei onized water, then rinsed with $1 \mathrm{~L}$ of groundwater prior to sampling. Each $250-\mathrm{mL}$ filtered sample then was preserved with 7.5-N ormal (N) nitric acid. Nutrient samples were collected by filtering groundwater into $125-\mathrm{mL}$ brown polyethylene bottles. A rsenic and iron species samples were filtered into $250-\mathrm{mL}$ polyethylene bottles that were covered with tape to prevent light exposure, and samples were preserved with 6-N hydrochloric acid. Samples to be analyzed for isotopes of dissolved boron and strontium in water were filtered into $250-\mathrm{mL}$ polyethylene bottles after bottles were rinsed with filtered groundwater and secured with electrical tape to prevent leakage and evaporation. Samples to be analyzed for gross al pha and gross beta particle activities were filtered into 1-L polyethylene bottles and acidified with 7.5-N nitric acid. Stable isotopes of carbon in dissolved inorganic carbon and carbon-14 abundance samples were filtered and bottom filled into $500-\mathrm{mL}$ glass bottles that first were overfilled with three bottle volumes of filtered groundwater. These samples had no headspace and were sealed with conical caps to avoid atmospheric contamination.

Chromium species samples were collected at the well head using a $10-\mathrm{mL}$ syringe with an attached $0.45-\mu \mathrm{m}$ poresize M IL LEX ${ }^{\circledR} \mathrm{HA}$ disk filter. After the syringe was rinsed thoroughly and filled with groundwater, the first $4 \mathrm{~mL}$ of water were forced through the filter to waste (to condition the filter), and the next $2 \mathrm{~mL}$ were filtered slowly into a small centrifuge vial for analysis of total chromium. Hexaval ent chromium then was collected by attaching a small cation-exchange column to the syringe filter and, after conditioning the column with $2 \mathrm{~mL}$ of sample water, an additional $2 \mathrm{~mL}$ of sample water was collected in a second centrifuge vial. B oth vials were preserved with 10 microliters $(\mu \mathrm{L})$ of $7.5-\mathrm{N}$ nitric acid (Ball and M cCleskey, 2003a, b).

For the collection of radon-222 samples, a stainless-steel and Teflon ${ }^{\circledR}$ valve assembly was attached to the sampling port at the well head (Wilde and others, 2004). The valve was closed partially to create back pressure, and a $10-\mathrm{mL}$ groundwater sample was taken through a Teflon ${ }^{\circledR}$ septum on the valve assembly by using a glass syringe affixed with a stainless-steel needle. The sample was then injected into a 25 -mL vial partially filled with a scintillation mixture (mineral oil and 1,2,4-trimethylbenzene) and shaken. The vial then was placed in an insulated cardboard tube to protect the sample during shipping.

Dissolved noble gases were collected in $3 / 8$-inch-diameter copper tubes using reinforced nylon tubing connected to the hose bib at the well head. Groundwater was flushed through the tubing to dislodge bubbles before the flow was restricted with a back-pressure valve. Clamps on either side of the copper tube then were tightened, trapping a sample of groundwater for analyses of dissolved noble gases (Weiss, 1968).

Field alkalinity was measured in the mobile laboratory at the well site. Samples for field alkalinity titrations were collected by filtering groundwater into a $500-\mathrm{mL}$ polyethylene bottle. Alkalinity was measured on filtered samples by Gran's titration method (Gran, 1952). Titration data were entered directly into PCFF, and the concentrations of bicarbonate $\left(\mathrm{HCO}_{3}^{-}\right)$and carbonate $\left(\mathrm{CO}_{3}{ }^{2-}\right)$ automatically were calculated from the titration data using the advanced speciation method (http://or.water.usgs.gov/alk/methods.html) with $\mathrm{pK}_{1}=6.35$, $\mathrm{pK}_{2}=10.33$, and $\mathrm{pK}_{\mathrm{w}}=14$. Concentrations of $\mathrm{HCO}_{3}{ }^{-}$and $\mathrm{CO}_{3}{ }^{2-}$ also were calculated from the laboratory alkal inity and laboratory $\mathrm{pH}$ measurements.

$\mathrm{N}$ ine laboratories performed chemical analyses for this study (table A 1), although most of the analyses were performed at the NW Q $L$ or by laboratories contracted by the NW QL. The NW QL maintains a rigorous QA program (Pirkey and Glodt, 1998; M aloney, 2005). Laboratory QC samples, including method blanks, continuing calibration verification standards, standard reference samples, reagent spikes, external certified reference materials, and external blind proficiency samples are analyzed regularly. M ethod detection limits are tested continuously, and laboratory reporting levels updated accordingly. The NW QL maintains National Environmental L aboratory A ccreditation Program (N ELAP) and other certifications (http://www.nelac-institute.org/accred-labs. php). The USGS B ranch of Q uality Systems (BQS) maintains independent oversight of QA at the NWQ L and laboratories contracted by the NW QL. The BQS also runs the National Field Quality A ssurance Program (NFQA) that includes annual testing of all USGS field personnel for proficiency in making field water-quality measurements (http://qadata. cr.usgs.gov/nfqa/). Results for analyses made at the NW QL or by laboratories contracted by the NW QL are uploaded directly into the USGS NWIS database. Results of analyses made at other laboratories are compiled in a project database and uploaded from there into NWIS. 


\section{Data Reporting}

The following section gives details for the laboratory reporting conventions and the constituents that are determined by multiple methods or by multiple laboratories.

\section{Reporting Limits}

The USGS NW QL uses different conventions for reporting results for organic and inorganic constituents. For organic constituents, a laboratory reporting level ( $L R L)$ and a long-term method detection level (LT-M DL) are used as thresholds for reporting analytical results. The $L R L$ is set to minimize the reporting of false negatives (not detecting a compound when it actually is present in a sample) to less than 1 percent (Childress and others, 1999). The LRL usually is set at two times the LT-M DL. The LT-M DL is derived from the standard deviation of at least 24 method detection limit (MDL) determinations made over an extended period of time. The M DL is the minimum concentration of a substance that can be measured and reported with 99-percent confidence that the concentration is greater than zero (at the M DL there is less than 1 percent chance of a false positive) (Childress and others, 1999; U.S. Environmental Protection A gency, 2002). Concentrations less than the LT-M DL are reported as nondetections with a dash (-) in the data tables.

The USGS NWQL updates LRL and LT-M DL values regularly, and the values listed in this report were in effect during the period that analyses were made for groundwater samples from the Santa B arbara study unit (J anuary to February 2011).

For organic constituents, concentrations between the $L R L$ and the LT-MDL are reported as having a higher degree of uncertainty (coded by the letter " $E$ " preceding the values in the tables and text). For information-rich methods, detections less than the LT-M DL have a high certainty of presence, but the precise concentration is uncertain. These values are also E-coded. Information-rich methods are those that utilize gas chromatography or high-performance liquid chromatography (HPLC) with mass spectrometry detection, such as those methods used to analyze V OCs and pesticides. Compounds are identified by presence of characteristic fragmentation patterns in their mass spectra in addition to being quantified by measurement of peak areas at their associated chromatographic retention times. E-coded values also may result from detections outside the range of calibration standards, from detections that did not meet all laboratory QC criteria, and from samples that were diluted prior to analysis (Childress and others, 1999).

For reporting detections of pharmaceutical compounds, GA M A uses more conservative reporting limits than are used by the NW QL. The M DL for each compound was selected as the maximum of up to five LT-MDLs used by the laboratory during the time period M ay 2004 through M arch 2010 (table 3D). Detections reported by the NW Q L with concentrations less than the selected M DL $s$ are reported as less than the MDL and are not considered detections when calculating detection frequencies (Fram and B elitz, 2011).

For most inorganic constituents, the LT-M DL is the only threshold used by the NW Q L for reporting analytical results. A II non-detections for inorganics constituents are reported in the N WIS database as less than the LT-M D L (except for non-detections of bromide, which are reported as less than the M DL); E-codes are not used to designate results with concentrations less than LRLS or LT-M DLS.

Total dissolved solids, perchlorate, and NDMA are reported by using minimum reporting levels (M RLs). The $M R L$ is the smallest measurable concentration of a constituent that may be reliably reported using a given analytical method (Timme, 1995).

I sotopes of hydrogen, oxygen, carbon, boron, and strontium are reported using method uncertainties (M U s). The MU generally indicates the precision of a particular analytical measurement; it gives a range of values wherein the true value will be found.

Results for most constituents are presented using the $L R L$, LT-MDL, MDL, MRL, or MU values provided by the analyzing laboratories. Results for some organic and inorganic constituents are presented using study reporting levels (SR Ls) derived from assessment of data from QC samples associated with groundwater samples collected as part of the GAMAPBP (see the appendix section titled "D etections in Field Blanks and A pplication of SR $L s^{\prime \prime}$ ).

The reporting limits for radiochemical constituents (carbon-14, tritium, radon-222, and gross alpha and gross beta radioactivity) are based on sample-specific critical levels (ssL ${ }_{c}$ ) (M cCurdy and others, 2008). The critical level is analogous to the LT-M DL used for reporting analytical results for organic and non-radioactive inorganic constituents. Here, the critical level is defined as the minimum measured activity that indicates a positive detection of the radionuclide in the sample with less than a 5-percent probability of a false positive detection. Sample-specific critical levels are used for radiochemical measurements because the critical level is sensitive to sample size and sample yield during analytical processing and is dependent on instrument background, on counting times for the sample and background, and on the characteristics of the instrument being used and the nuclide being measured. A $n s s L_{c}$ is calculated for each sample, and the measured activity in the sample is compared to the $s s L_{\text {c }}$ associated with that sample. M easured activities less than the $s s L_{C}$ are reported as non-detections with a dash (-) in the data tables.

The analytical uncertainties associated with measurement of activities also are sensitive to sample-specific parameters, including sample size, sample yield during analytical processing, and time elapsed between sample collection and various steps in the analytical procedure, as well as parameters associated with the instrumentation. Therefore, measured activities of radioactive constituents are reported with samplespecific combined standard uncertainties (CSUs). The CSU is reported at the 68-percent confidence level (1-sigma). The 
SSL was not reported by the laboratory for some tritium results, in which case the CSU was used as an estimated reporting level.

\section{Notation}

Stable isotopic compositions of oxygen, carbon, boron, and hydrogen are reported as relative isotope ratios in units of per mil using the standard delta notation (Coplen and others, 2002):

$$
\delta^{i} E=\left[\frac{R_{\text {sample }}}{R_{\text {reference }}}-1\right] \times 1,000 \text { per mil }
$$

where

$$
\begin{gathered}
\text { i is the atomic mass of the heavier isotope of } \\
\text { the element, } \\
\text { is the element ( } \mathrm{H} \text { for hydrogen, } \mathrm{O} \text { for oxygen, } \\
\mathrm{B} \text { for boron, } \mathrm{C} \text { for carbon), } \\
\text { is the ratio of the abundance of the heavier } \\
\text { isotope of the element }\left({ }^{2} \mathrm{H},{ }^{18} \mathrm{O},{ }^{11} \mathrm{~B},{ }^{13} \mathrm{C}\right) \text { to } \\
\text { the lighter isotope of the element }\left({ }^{1} \mathrm{H},{ }^{16} \mathrm{O},\right. \\
\left.{ }^{10} \mathrm{~B},{ }^{12} \mathrm{C}\right) \text { in the sample, and } \\
\text { is the ratio of the abundance of the heavier } \\
\text { isotope of the element to the lighter isotope } \\
\text { of the element in the reference material. }
\end{gathered}
$$

The reference material for oxygen and hydrogen is Vienna Standard M ean Ocean Water (V SM OW), which is assigned $\delta^{18} \mathrm{O}$ and $\delta^{2} \mathrm{H}$ values of 0 per mil (note that $\delta^{2} \mathrm{H}$ is sometimes written as $\delta \mathrm{D}$ because the common name of the heavier isotope of hydrogen, hydrogen-2, is deuterium) (Coplen and others, 2002). The reference material for carbon is Vienna Pee Dee B elemnite (V PDB ), which is assigned a $\delta^{13} \mathrm{C}$ value of 0 per mil (Coplen and others, 2002). Positive values indicate enrichment of the heavier isotope, and negative values indicate depletion of the heavier isotope, compared to the ratios observed in the standard reference material.

The isotopic composition of strontium is presented as the abundance of atoms of the heavier isotope $\left({ }^{87} \mathrm{Sr}\right)$ to the lighter isotope $\left({ }^{86} \mathrm{Sr}\right)$ of the element.

\section{Constituents on Multiple Analytical Schedules}

Thirteen constituents targeted in this study were measured by more than one analytical method or by more than one laboratory (table A 2). Preferred analytical methods generally were selected on the basis of better performance or sensitivity for the constituent, or (in some cases) to provide consistency with historical data from the same method. Six organic constituents (atrazine, deethylatrazine, tebuthiuron, caffeine, metalaxyl, and carbaryl; table 3) each were analyzed by two analytical methods for the Santa B arbara study unit; however, none of the six constituents were detected by either method.
The field water-quality indicators alkalinity, $\mathrm{pH}$, and specific conductance were measured in the field and at the NW Q L (table 4). Field measurements are generally preferred because they are considered more representative of groundwater conditions by limiting the amount of time for reactions in the water and exposure to the atmosphere to occur (Hem, 1985). Field values of $\mathrm{pH}$ and specific conductance were measured at each Santa B arbara well. D ue to time constraints, field alkalinities were measured at 12 percent of the wells in order to confirm that differences between lab and field alkalinity values are negligible for the purpose of this study.

For total arsenic, chromium, and iron concentrations, the approved method used by the NW Q L, Schedule 1948 (table 3F), is preferred over the research methods used by the USGS Trace M etal L aboratory (table 31).The concentrations measured by the USGS Trace M etal Laboratory only are used to calculate ratios of redox species for arsenic, chromium, and iron.

For example,

$$
\frac{\mathrm{Cr}(\mathrm{III})}{\mathrm{Cr}(\mathrm{VI})}=\frac{\mathrm{Cr}(\mathrm{T})-\mathrm{Cr}(\mathrm{VI})}{\mathrm{Cr}(\mathrm{VI})},
$$

where

$\mathrm{Cr}(\mathrm{T})$ is the total chromium concentration (measured);

$\mathrm{Cr}(\mathrm{VI})$ is the concentration of hexavalent chromium (measured); and

$\mathrm{Cr}(\mathrm{III})$ is the concentration of trivalent chromium (cal culated).

A dditionally, tritium was measured at two laboratories: LLNL and USGS Stable Isotope and Tritium L aboratory (SITL), although only tritium data from the SITL were available for reporting at the time of this publication.

\section{Quality-Control Methods and Results}

The purpose of QC is to identify which data best represent environmental conditions and which may have been affected by contamination or bias during sample collection, processing, storage, transportation, and (or) laboratory analysis. Four types of QC tests were evaluated in this study: (1) blank samples were collected to assess positive bias as a result of contamination during sample handling or analysis, (2) replicate samples were collected to assess variability, (3) matrix-spike tests were done to assess positive or negative bias, and (4) surrogate compounds were added to samples analyzed for organic constituents to assess potential bias of laboratory analytical methods. 


\section{Blanks}

The primary purposes of collecting blanks are to evaluate the magnitude of potential contamination of samples with compounds of interest during sample handling or analysis and to identify and mitigate the sources of sample contamination. Results from blanks collected for the Santa B arbara study unit and for previous GAM A study units were used to establish study reporting levels (SRLs) for some constituents detected in blanks. SRLs have higher concentrations than the reporting levels used by the laboratory. Detections reported by the laboratory with concentrations less than SRLs may have significant contamination bias. These data were flagged with an appropriate remark code (described in subsequent sections).

\section{Blank Collection and Analysis}

Blanks were collected using blank water certified by the NW Q L to contain less than the reporting levels for selected constituents investigated in the study (J ames A. L ewis, National Water Quality Laboratory, written commun., 2012). Nitrogen-purged, organic-free blank water was used for blanks of organic constituents, and inorganic-free blank water was used for blanks of other constituents.

Source-solution blanks are collected at the beginning of a study or when using a new lot of blank water to assess potential contamination of samples during transport and analysis and potential contamination of the certified blank water obtained from the NW Q L. Source-solution blanks were collected in the USGS San Diego Projects Office laboratory by pouring blank water directly into sample containers that were preserved, stored, shipped, and analyzed in the same manner as the groundwater samples. Source-solution blanks were analyzed for VOCs, perchlorate, pharmaceutical compounds, NDM A, perchlorate, trace elements, major and minor ions, silica, and TDS. Three additional source-solution blanks were collected at sampling sites for perchlorate analysis.

Field blanks were collected to assess potential contamination of samples during collection, processing, transport, and analysis. To collect field blanks at the sampling sites, blank water was either pumped or poured through the sampling equipment (fittings and tubing) used to collect groundwater samples, then processed and transported using the same protocols used for the groundwater samples. Four liters of blank water were pumped or poured through the sampling equipment before each field blank was collected. Field blanks were analyzed for V OCs, pesticides (including polar pesticides) and pesticide degradates, pharmaceutical compounds, NDMA, perchlorate, trace el ements, nutrients, major and minor ions, silica, TDS, and arsenic, chromium, and iron species.

Field or source-solution blanks were not collected for gross al pha and gross beta radioactivity or radon because the laboratory determines an $\mathrm{Ss}_{\mathrm{C}}$ value for each sample. The $\mathrm{SsL}_{c}$ is the minimum measured value that indicates a non-zero amount of the radionuclide in the sample, in other words, an amount of the radionuclide that is statistically significantly greater than the amount in a blank. B lanks were not collected for tritium and dissolved noble gases. Tritium and dissolved noble gases are in the atmosphere and would dissolve into any solution used in collecting a blank, making it impractical to collect a blank for these analytes. Isotopic ratios of carbon, boron, hydrogen, oxygen, and strontium are an intrinsic property of any of these elements; therefore, the concept of a blank does not apply to these ratios.

\section{Study Reporting Levels (SRLs)}

SRLs for VOCs detected in field blanks collected for the first 32 GAMA-PBP study units (May 2004 through September 2010) were defined by Fram and others (2012) on the basis of assessment of results from field blanks, source-solution blanks, laboratory instrument blanks, and groundwater samples. Detections of V OCs having concentrations less than the SR L $s$ are reported as nondetections in table 5 .

SRLs for trace elements detected in field blanks collected in the first 20 GAMA-PBP study units (May 2004 through January 2008) were defined by Olsen and others (2010) on the basis of statistical assessment of results from the field blanks. The assessment used order statistics and binomial probabilities to construct an upper confidence limit (Hahn and M eeker, 1991) for the maximum concentration of constituents possibly introduced while groundwater samples were collected, handled, transported, and analyzed. Detections of trace elements having concentrations less than the SRLS are marked with a symbol preceding the reported value in table 8 to indicate that the true value may be less than or equal to the reported value (including the possibility of being a non-detection).

SRLs for other classes of constituents detected in field blanks collected for the Santa Barbara study unit were defined as equal to the highest concentration measured in the field blanks.

\section{Detections in Field Blanks and Application of SRLs}

Table A 3 presents a summary of detections in the field blanks and the SRL s applied for the Santa B arbara study unit. Three field blanks (representing approximately 12 percent of the sampled sites) were collected in the Santa B arbara study unit. No constituents were detected in the source-solution blanks collected during the Santa Barbara study.

VOCs were not detected in the field blanks for the Santa Barbara study unit (table A 3). Of the $10 \mathrm{~V} \mathrm{OCs} \mathrm{with} \mathrm{SRLs}$ defined by Fram and others (2012), only two were detected in groundwater samples from the Santa B arbara study unit: 1,2,4-trimethyl benzene and chloroform. All four detections for 1,2,4-trimethyl benzene had concentrations less than the SRL of $0.56 \mu \mathrm{g} / \mathrm{L}$ and were thus reclassified as non-detections in the Santa B arbara study unit dataset (table 5). For the GA M A $\mathrm{PBP}$, concentrations of 1,2,4-trimethyl benzene in blanks and groundwater samples less than $0.56 \mu \mathrm{g} / \mathrm{L}$ were found to be 
correlated with the presence of equipment used for collecting radon samples in field vehicles (Fram and others, 2012). The vials used to collect radon samples contain a scintillation cocktail made of mineral oil and 1,2,4-trimethylbenzene. Samples for radon analysis were collected at 22 sites in the Santa B arbara study unit.

The SRL of $0.20 \mu \mathrm{g} / \mathrm{L}$ for chloroform was defined by Fram and others (2012) for monitoring wells that require special sampling equipment. The length and complexity of the lines used with the equipment, such as the G runfos ${ }^{\circledR}$ submersible pump, are much greater than for the long and short lines sampling configurations. However, the monitoring wells sampled for the Santa B arbara study unit were artesian (groundwater under positive pressure) and were sampled with short lines similar to those used for the other 20 wells. Therefore, the SRL was not applied to any chloroform detections in the Santa B arbara study unit dataset.

The application and concentration of an SRL for each trace element were determined primarily by $O \mathrm{Isen}$ and others (2010) based on a statistical assessment of quality-control results from 2004 to 2008. GA M A SRLs from Olsen and others (2010) were used for barium, chromium, copper, iron, lead, nickel, tungsten, vanadium, and zinc for the Santa B arbara study unit (table A 3). Of these trace elements, four were detected in at least one Santa Barbara field blank: copper, iron, lead, and zinc. Field blank detections were at concentrations below the $S R L$ for each constituent, with the exception of one iron detection $(7.2 \mu \mathrm{g} / \mathrm{L})$ and one lead detection $(0.87 \mu \mathrm{g} / \mathrm{L})$.

For the trace elements cobalt and manganese, the concentrations and detection frequencies in field blanks collected for the Santa B arbara study unit suggest that the dataset of field blanks used by Olsen and others (2010) may not be representative of conditions encountered during collection of samples in the Santa B arbara study unit. Cobalt was detected in all three field blanks at concentrations ranging from 0.05 to $0.22 \mu \mathrm{g} / \mathrm{L}$; manganese was detected at concentrations ranging from 0.24 to $0.47 \mu \mathrm{g} / \mathrm{L}$ (table A 3). SRLs for cobalt and manganese were defined based on these results, at $0.22 \mu \mathrm{g} / \mathrm{L}$ and $0.47 \mu \mathrm{g} / \mathrm{L}$, respectively. M easured concentrations in groundwater samples that were less than the SRLs were flagged with a $\leq$ symbol in table 8 .

Olsen and others (2010) also assigned an SRL of $1.6 \mu \mathrm{g} / \mathrm{L}$ for al uminum; however, the NW QL has since raised the detection level to $1.7 \mu \mathrm{g} / \mathrm{L}$ based on laboratory performance. (See the appendix section titled "Other Quality-Control Results" for analysis of BQS data for al uminum.) No SRL was defined for aluminum for the Santa Barbara study unit.

Ammonia was detected in one field blank at a concentration of $0.013 \mathrm{mg} / \mathrm{L}$ (table A 3). This concentration was used as the SRL for ammonia for the Santa B arbara study unit dataset. The SRL resulted in the censoring of no detections because there were no measured concentrations of ammonia less than $0.013 \mathrm{mg} / \mathrm{L}$ in the groundwater samples (table 9).
Constituents were not detected in field blanks for the following analyte groups: pesticides (including polar pesticides) and pesticide degradates; pharmaceutical compounds; perchlorate; NDM A; major and minor ions, silica, and TDS; and arsenic, chromium, and iron species.

\section{Replicates}

Sequential replicate samples were collected to assess the precision of the water-quality data. Estimates of data precision are needed to assess whether differences between concentrations in samples are because of differences in groundwater quality or because of variability that may result from collecting, processing, and analyzing the samples.

\section{Assessment of Replicate Samples}

Two methods for measuring variability were needed to adequately assess precision over the broad range of measured concentrations of most constituents. The variability between measured concentrations in the pairs of sequential replicate samples was represented by the standard deviation (SD) for low concentrations and by relative standard deviation (RSD) for high concentrations (A nderson, 1987; M ueller and Titus, 2005). The RSD is defined as the SD divided by the mean concentration for each replicate pair of samples expressed as a percentage. The boundary between concentrations for which variability is assessed with SD and concentrations for which variability is assessed with RSD was defined as five times the reporting level $(R L)$ for each constituent. The $R L$ may be an $L R L, S R L, M D L$, or $M R L$ for each constituent.

Replicate pairs of analyses of all constituents except for radiochemical constituents were evaluated as follows:

- If both values were reported as detections, the SD was calculated if the mean concentration was $<5 \mathrm{RL}$ for the constituent, or the RSD was calculated if the mean concentration was $\geq 5 \mathrm{RL}$ for the constituent. Acceptable precision is defined as an $\mathrm{SD}$ of less than $1 / 2 R L$ or an RSD of less than 10 percent. For comparison, an RSD of 10 percent is equivalent to a relative percent difference (RPD) of 14 percent.

- If both values were reported as non-detections, the variability was set to zero by definition.

- If one value was reported as a non-detection and the other value was reported as a detection less than the $R L$, then a value of zero was substituted for the nondetection and the SD was calculated. Substituting zero for the non-detection yielded the maximum estimate of variability for the replicate pair. 
- If one value for a sample pair was reported as a nondetection and the other value was reported as a $\leq$-coded value (less than or equal to the $S R L$ ), or if both values were reported as $\leq$-coded values (less than or equal to the $S R L$ ), the SD was not calculated because the values may be analytically identical. The $\leq$ code indicates that the value is a maximum potential concentration, and that concentration may be low enough to be reported as a non-detection.

- If one value was reported as a non-detection and the other value was reported as a detection greater than the $R L$, the variability for the pair was considered unacceptable.

Replicate pairs of analyses of radiochemical constituents were evaluated using the following equation ( $\mathrm{M} \mathrm{cC}$ urdy and others, 2008) to calculate the normalized absolute difference, NAD:

$$
N A D=\frac{\left|R_{1}-R_{2}\right|}{\sqrt{\left(C S U_{1}^{2}+C S U_{2}^{2}\right)}},
$$

where

$R_{1}, R_{2}$ are the results for the two samples in the replicate pair, and

$\mathrm{CSU}_{1}, \mathrm{CSU}_{2}$ are the combined standard uncertainties associated with the results.

Values of NAD $<1.65$ correspond to a significance levels $(\alpha)$ of 5 percent $(\alpha=0.05)$, indicating differences that are acceptably small and not statistically significant.

If results from replicate sample pairs indicate that precision is unacceptable for a constituent and no specific reason can be identified, then this greater variability must be considered when interpreting the data. If measured concentrations are slightly greater than a water-quality benchmark, then actual concentrations could be slightly less than that benchmark. Similarly, if measured concentrations are slightly less than a water-quality benchmark, then actual concentrations could be slightly greater than a benchmark. Also, if a constituent has high variability in replicate sample pairs, then a larger difference between concentrations measured in two samples is required to conclude that the two samples have significantly different concentrations.

\section{Variability in Replicate Samples}

Tables A 4A-C summarize the results of replicate analyses for constituents detected in groundwater samples collected in the Santa Barbara study unit. Replicate analyses were made at three sites, representing approximately 12 percent of all of the samples collected.

Of the 854 replicate pairs of constituents analyzed, 198 pairs had a detection in one or both samples of the pair. Of these 198 pairs, 8 pairs (simazine, iron, total chromium [three pairs], chromium [VI], iron [II], and gross al pha radioactivity [30-day count]) were outside the limits for acceptable precision. Results for replicate analyses for constituents that were not detected in groundwater samples are not reported in tables A 4 A - C.

A II replicate pairs of samples analyzed for VOC s were within limits for acceptable precision. One V OC replicate pair had non-detections with different $L R L s$ for two constituents (carbon disulfide and trans-1,4-dichloro-2-butene) due to interference caused by high levels of sulfur in a previous sample set at the NW QL.

Replicate pairs of samples were analyzed for 120 pesticides (including polar pesticides) and pesticide degradates and 13 pharmaceutical compounds. All pairs of samples analyzed were composed of non-detections with the exception of one replicate pair of simazine. The replicate pair consisted of a non-detection $(<0.006 \mu \mathrm{g} / \mathrm{L})$ and a value above the $L R L(0.007 \mu \mathrm{g} / \mathrm{L})$, yielding variability considered unacceptable (table A 4A).

Three replicate pairs of samples were analyzed for the 24 trace elements. Of the 72 replicate pairs, 17 were composed of either two values reported as non-detections, a value reported as a non-detection and a value reported as less than or equal to the $S R L$, or two values reported as less than or equal to the $S R L$. Of the remaining 55 pairs of constituents, the SD value was greater than half of the LT-M DL for iron $(10.6 \mu \mathrm{g} / \mathrm{L}$ and - ) for one replicate pair (table A 4B).

Replicate pairs analyzed for nutrients, major ions, TDS, and isotope tracers resulted in SD and RSD values within acceptable precision. Three replicate sets of samples were analyzed for arsenic, chromium, and iron species. Twelve pairs were composed of non-detections and (or) were within the acceptable range of precision, and 5 pairs (total chromium [3 pairs], chromium [VI], and iron [II]) had RSD or SD values outside the limits for acceptable precision (table A 4B).

Replicate pairs of radioactive constituents were analyzed for variability, including one radon pair with a sample volume discrepancy caused during sample collection. M ost pairs yielded statistically similar results $(\mathrm{p} \leq 0.05)$ and were, therefore, considered acceptable. The exception was one gross al pha radioactivity (30-day count) pair that was considered unacceptable $(p>0.05)$ (table A 4C).

Environmental detections were not modified on the basis of the replicate analyses.

\section{Matrix Spikes}

The addition of a known concentration of a constituent (spike) to a replicate environmental sample enables the laboratory to determine the effect of the matrix, in this case groundwater, on the analytical technique used to measure the constituent. The known compounds added in matrix spikes are the same as those analyzed in the environmental samples. This enables an analysis of matrix interferences on a compoundby-compound basis. For this study, matrix spikes were added by the laboratory performing the analysis rather than in the field. Low matrix-spike recovery may indicate that the 
compound might not be detected in some samples if it were present at very low concentrations. Low and high matrix-spike recoveries may be a potential concern if the concentration of a compound in a groundwater sample is close to the healthbased benchmark; a low recovery could result in a falsely measured concentration less than the health-based benchmark, whereas a high recovery could result in a falsely measured concentration greater than the health-based benchmark.

The GAMA-PBP defined the data-quality objective range for acceptable median matrix-spike recoveries as 70 to 130 percent. Only constituents with median matrixspike recoveries outside of this range were flagged as having unacceptable recoveries. For some constituents, an acceptable range of 70 to 130 percent for median matrix-spike recovery was more restrictive than the acceptable control limits for laboratory-set spike recoveries. L aboratory-set spikes are al iquots of laboratory blank water to which the same spike solution used for the matrix spikes has been added. One set spike is analyzed with each set of samples. Acceptable control limits for set spikes are defined relative to the long-term variability in recovery. For example, for many NW QL analyses, acceptable set-spike recovery is within \pm 3 F-pseudosigma of the median recovery for at least 30 set spikes (Connor and others, 1998). The F-pseudosigma is calculated by dividing the fourth-spread (analogous to interquartile range) by 1.349; therefore, the smaller the F-pseudosigma, the more precise the determinations (H oaglin, 1983).

$M$ atrix-spike tests were performed for VOCs, pesticides (including polar pesticides), pesticide degradates, pharmaceutical compounds, and NDM A because the analytical methods for these constituents may be susceptible to matrix interferences.

\section{Matrix-Spike Recoveries}

Tables A 5A-E present a summary of matrix-spike recoveries for the Santa Barbara study unit. Replicate samples for spike additions of organic constituents were collected at three sites, representing approximately 12 percent of all the wells sampled.

Groundwater samples were spiked with 85 V OCs to calculate matrix-spike recoveries. M edian matrix-spike recoveries were between 70 and 130 percent for all VOCs, except for one constituent detected in groundwater samples: dichlorodifluoromethane (CFC-12). This compound had two matrix spike recoveries less than 70 percent (table A 5A).

Groundwater samples were spiked with 63 pesticides and pesticide degradates to calculate matrix-spike recoveries. Twenty compounds had median matrix-spike recoveries less than 70 percent, none of which were detected in groundwater samples (table A 5B).

Groundwater samples were spiked with 56 polar pesticides and degradates to calculate matrix-spike recoveries. Ten compounds had median matrix-spike recoveries less than 70 percent, and 6 had recoveries greater than 130 percent, none of which were detected in groundwater samples (table A 5C). Results for the compounds included in spiking solutions for both pesticide schedules are reported for the preferred method only (NW Q L Schedule 2003, table A 5B) and were omitted from table A 5 C.

$G$ roundwater samples were spiked with 14 pharmaceutical compounds to calculate matrix-spike recoveries. Four compounds had median matrix-spike recoveries less than 70 percent, none of which were detected in groundwater samples (table A 5D). Results for the compounds included in spiking solutions of multiple analytical schedules are reported for the preferred method only (N W Q L Schedule 2060, table A 5C) and were omitted from table A 5D. A Il three matrix-spike recoveries for NDM A were within the acceptable range of 70 to 130 percent (table A 5D).

Environmental detections were not modified on the basis of the matrix-spike recovery analysis.

\section{Surrogates}

Surrogate compounds are added to environmental samples in the laboratory prior to analysis to evaluate the recovery of similar constituents. Surrogate compounds were added in the laboratory to all groundwater and QC samples that were analyzed by the NWQL for VOCs, pesticides (including polar pesticides), and pesticide degradates. Surrogates are used to identify general problems that may arise during laboratory sample analysis that could affect the results for all compounds in that sample. Potential problems include matrix interferences (such as high levels of dissolved organic carbon) that produce a positive bias or incomplete laboratory recovery (possibly because of improper maintenance and calibration of analytical equipment) that produces a negative bias. A 70 to 130 percent recovery of surrogates, in general, is considered acceptable; values outside this range indicate possible problems with the processing and analysis of samples (Connor and others, 1998; Sandstrom and others, 2001).

\section{Surrogate Compound Recoveries}

Table $A 6$ presents a summary of the surrogate recoveries for the Santa Barbara study unit. The table lists the surrogates, the analytical schedule for which each surrogate was used, the number of analyses for field blanks and environmental samples, the number of surrogate recoveries less than 70 percent, and the number of surrogate recoveries greater than 130 percent for the blank and environmental samples. Field blanks and environmental samples were considered separately to assess whether or not the matrixes present in environmental samples affect surrogate recoveries.

Most surrogate recoveries for the field blanks and environmental samples were within the acceptable range of 70 to 130 percent. For VOC analyses, 100 percent of the field blank and 99 percent of the environmental sample surrogate recoveries were within the acceptable range. For pesticides and pesticide degradates, 100 percent of the field blank and 
98 percent of the environmental sample surrogate recoveries were within the acceptable range. For polar pesticides and degradates, 89 percent of the blank and 90 percent of the environmental sample surrogate recoveries were within the acceptable range. For pharmaceutical compounds, 100 percent of the blank and 92 percent of the environmental sample surrogate recoveries were within the acceptable range (tableA 6). There were no significant differences between surrogate recoveries in field blanks and environmental samples (Wilcoxon rank-sum test, $p<0.05$ ).

Environmental detections were not modified on the basis of the surrogate recovery analysis.

\section{Other Quality-Control Results}

Two other laboratory QC issues arose during the analysis of samples collected for the Santa B arbara study unit: the effect of holding-time violations on the results of radioactive constituent data and the effect of internal laboratory QC tests indicating bias on the results of trace el ement data.

$\mathrm{H}$ olding time refers to the time in calendar days from sample collection to the analysis of the sample. A holdingtime violation occurs when a sample is analyzed past the given holding time for a particular analysis. A nalyses for some samples in the Santa B arbara study unit were completed after the given holding time due to a scheduling error at the laboratory or a shipping error. A delay in the analysis at the laboratory may result in different measured activities or concentrations than what may have been present in the sample.

NDMA has a holding time of 7 days to minimize the risk of the compound degrading prior to analysis. One groundwater sample and the associated field blank for NDMA analysis (table $3 \mathrm{E}$ ) exceeded this holding time due to a shipping error. NDM A was not detected in this sample, but if the sample had been analyzed on time, NDM A may have been detected at very low concentrations.

The gross alpha and beta radioactivity reported result is the amount measured in the sample. Radioactive decay occurs between the time of sample collection and measurement; therefore, gross al pha and gross beta radioactivity can change with time. A t least one result from the analysis of gross alpha and beta radioactivity (72-hour counts) was analyzed past the holding time in each of five groundwater and quality-control samples. The results for these five samples are footnoted in tables 13B or A 4C. G ross al pha radioactivity (72-hour) may be lower and gross beta radioactivity (72-hour) may be lower or higher in samples analyzed past the holding time than they would have been if analyzed on time. One of the Santa B arbara study unit samples had a gross al pha radioactivity result near the benchmark and was analyzed 5 days past the collection time.

L aboratory bias as indicated from internal laboratory QC tests is another issue that must be investigated to determine whether or not the data are affected. The BQS operates independent, external quality-assurance projects called the Inorganic Blind Sample Project (IBSP) and Blind
Blank Program (BBP) to monitor and evaluate the quality of results for analyses of trace elements, nutrients, major and minor ions, silica, and TDS by the NW QL. The IBSP submits standard reference samples consisting of natural matrix water samples spiked with reagent chemicals to contain known concentrations of the inorganic constituents (Farrar and L ong, 1997). The IBSP samples are disguised as regular environmental samples for submission to the NW QL ; the B B P samples are disguised as regular blank samples. The $B Q S$ uses results from the IBSP and BBP samples to evaluate potential bias in the results reported by the NWQL on a continuous basis. The BQS data are readily available on the $B Q S$ website, and the BQS issues summaries of the results, reporting the amount of bias (if any) observed in the results (U.S. Geological Survey, 2011c, d, website at http://bqs.usgs. gov/ibsp/).

The A pril 2011 BQS summary, which includes a review of data for the time period September 1, 2010, through $M$ arch 31, 2011, was examined. The B QS reported that three inorganic constituents showed evidence of bias during this period: a positive bias for aluminum in blind blanks, a positive bias for zinc in blind non-blanks, and a negative bias for uranium. Examination of the results for the IBSP samples for these three constituents indicated that the analytical biases reported by the BQS were not significant for the data collected for the Santa Barbara study unit.

During the time which samples for the Santa B arbara study unit were analyzed (J anuary through M arch 2011), 1 of the 15 blind blanks analyzed (6.7 percent) was measured at a concentration greater than the LT-M DL: $2.74 \mu \mathrm{g} / \mathrm{L}$. A dditionally, two of the three replicate pairs for al uminum collected for the Santa B arbara study unit were re-analyzed by the NW Q L due to disagreement between the environmental and replicate samples. The samples, which initially had reported values for al uminum ranging from non-detection to $22.1 \mu \mathrm{g} / \mathrm{L}$, were all adjusted by the lab to non-detections upon re-analysis.

The B B P and replicate data demonstrated variability for al uminum at low concentrations; however, the IBSP data indicate that the variability is not significant for this particular study. The IBSP non-blank samples for al uminum, analyzed J anuary through $M$ arch 2011, had concentrations ranging from $33.8 \mu \mathrm{g} / \mathrm{L}$ to $144 \mu \mathrm{g} / \mathrm{L}$. The average difference between the measured and expected concentrations was $-0.5 \mu \mathrm{g} / \mathrm{L}$ (standard deviation $=3 \mu \mathrm{g} / \mathrm{L}$ ). The maximum concentration of aluminum for the Santa B arbara study unit was $5.2 \mu \mathrm{g} / \mathrm{L}$ (table 8), and a difference of $0.5 \mu \mathrm{g} / \mathrm{L}$ does not affect assessment of whether groundwater samples in the Santa $B$ arbara study unit have aluminum concentrations greater than or less than the M CL-CA concentration $(1,000 \mu \mathrm{g} / \mathrm{L})$ or greater than or less than one-half of the M CL-CA concentration.

The IBSP non-blank blind samples for zinc had concentrations ranging from $9 \mu \mathrm{g} / \mathrm{L}$ to $840 \mu \mathrm{g} / \mathrm{L}$, with positive bias demonstrated primarily at the high end due to instruments set to achieve lower detection levels. The average difference 
between the measured and expected concentrations was $37 \mu \mathrm{g} / \mathrm{L}$ (standard deviation $=36 \mu \mathrm{g} / \mathrm{L}$ ), and the average relative percent difference between the measured and expected concentrations was 7 percent (standard deviation $=5$ percent). The maximum concentration of zinc in samples for the Santa Barbara study unit is $73.7 \mu \mathrm{g} / \mathrm{L}$, a value less than $1 / 10$ of the concentrations showing most bias ( $800 \mu \mathrm{g} / \mathrm{L}$ or above), and much lower than the SM CL-CA for zinc $(5,000 \mu \mathrm{g} / \mathrm{L})$. Thus, the estimate of bias from the ISBP samples would not be relevant for assessment of whether groundwater samples have zinc concentrations greater than or less than the SM CL -CA concentration or greater than or less than one-half of the SM CL-CA concentration.

The negative bias for uranium demonstrated by IBSP samples started in December 2010; however, results were within acceptable bias and variability during the time period Santa B arbara study unit samples were analyzed. The IB SP samples for uranium (J anuary through M arch 2011) had concentrations ranging from 0.28 to $1.4 \mu \mathrm{g} / \mathrm{L}$. The average difference between measured and expected concentrations was $-0.03 \mu \mathrm{g} / \mathrm{L}$ (standard deviation $=0.04 \mu \mathrm{g} / \mathrm{L}$ ), and the average relative percent difference between the measured and expected concentrations was -4 percent (standard deviation = 5 percent). However, the maximum concentration of uranium in samples from the Santa B arbara study unit was $14.4 \mu \mathrm{g} / \mathrm{L}$; thus, a potential negative bias of $0.6 \mu \mathrm{g} / \mathrm{L}$, or 4 percent, does not affect assessment of whether groundwater samples in the Santa B arbara study unit have uranium concentrations greater than or less than the M CL -US of $30 \mu \mathrm{g} / \mathrm{L}$. M oreover, the bias observed in the IB SP samples was the highest at concentrations close to the LT-M DL and does not imply that there is equivalent bias at higher concentrations. 


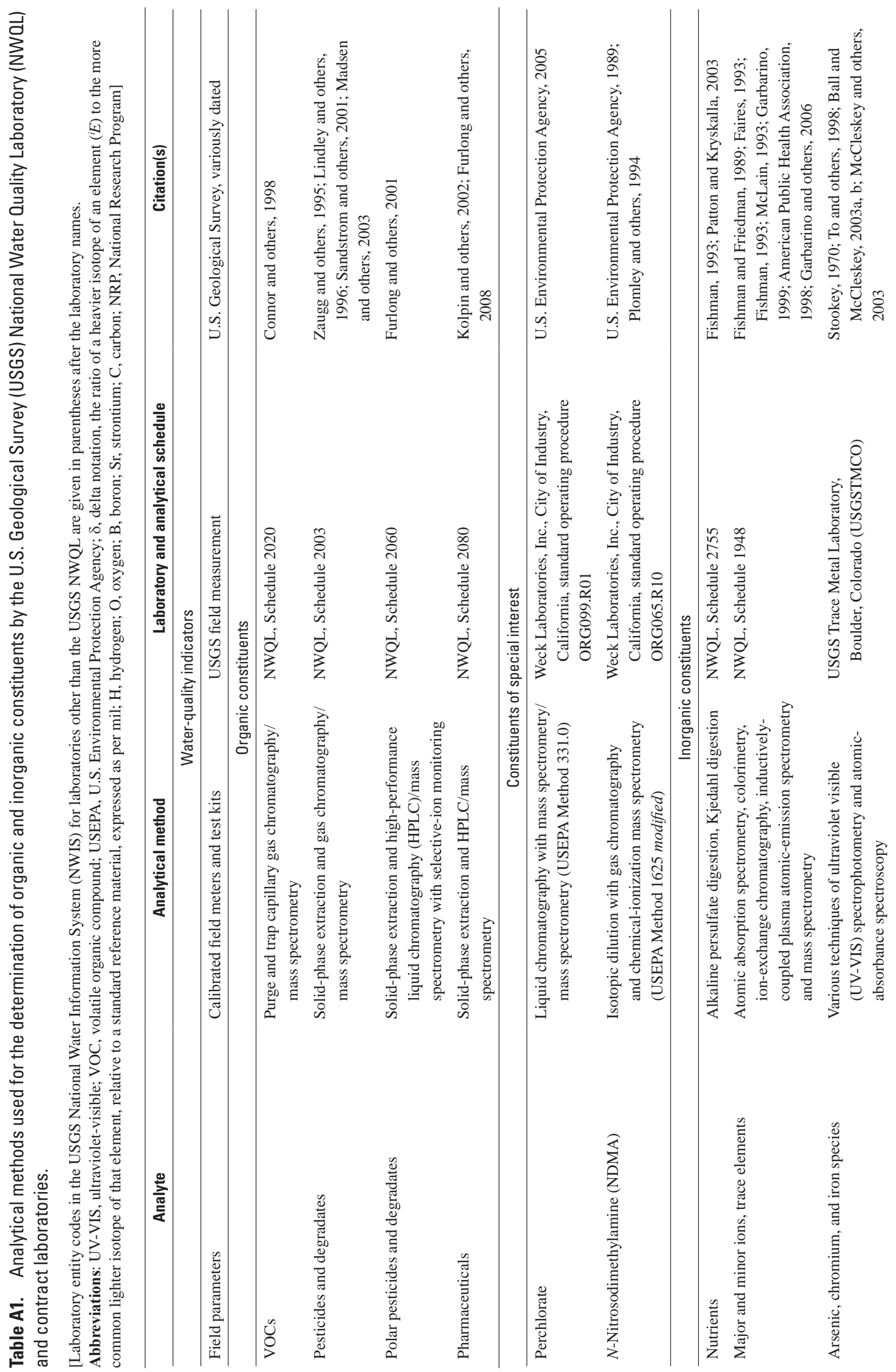




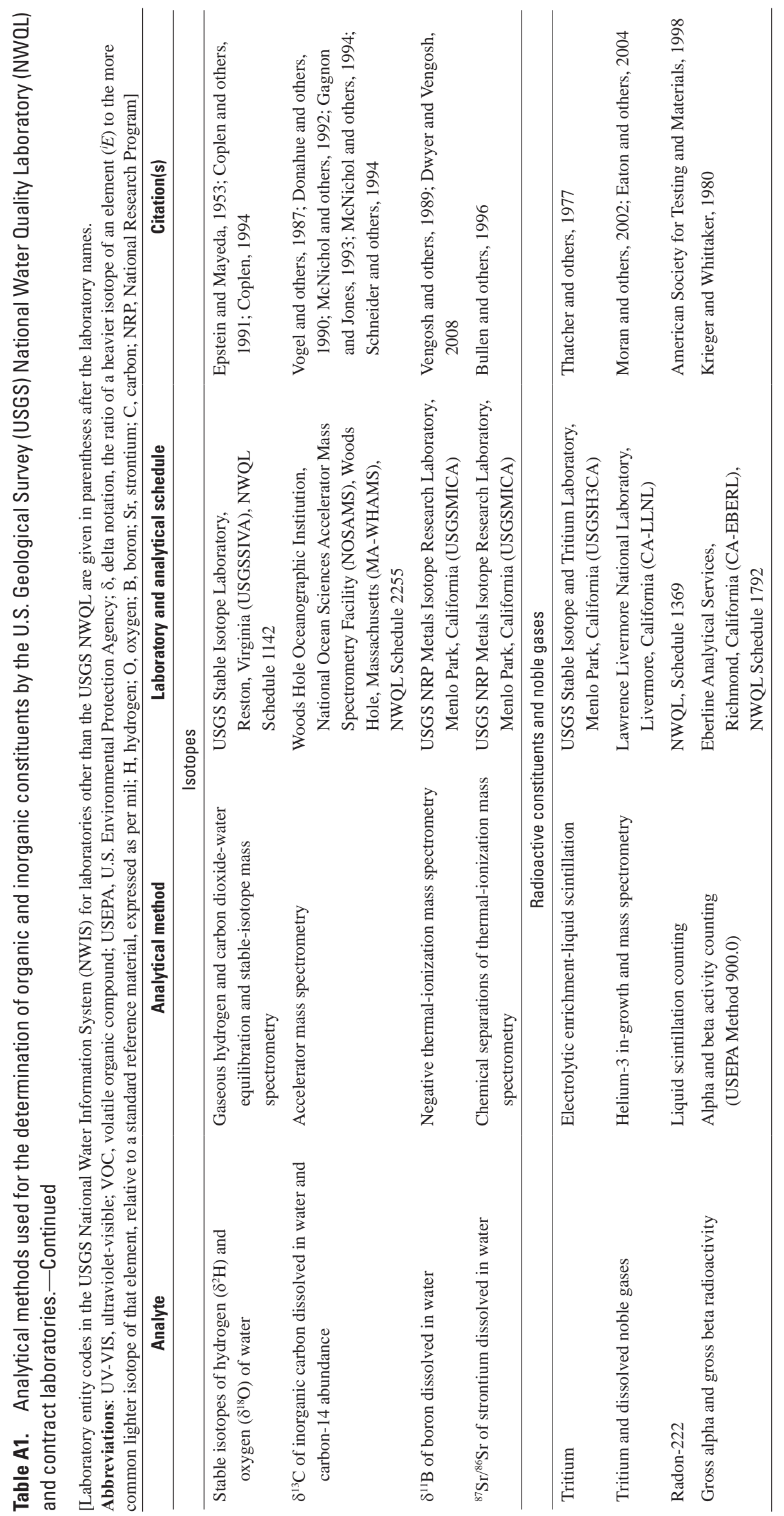


Table A2. Preferred analytical schedules for selected constituents collected for the Santa Barbara study unit, January to February 2011, California GAMA Priority Basin Project.

[Preferred analytical schedules/methods are selected on the basis of the procedure recommended by the U.S. Geological Survey (USGS) National Water Quality L aboratory (NW QL) (http://wwwnwql.cr.usgs.gov/dyn.shtml?Preferred_method_selection_procedure). Abbreviations: TM L, U.S. Geological Survey Trace M etal Laboratory, B oulder, Colorado; LL NL, Lawrence Livermore National L aboratory, Livermore, California; SITL, U.S. Geological Survey Stable Isotope and Tritium Laboratory, Reston, Virginia; np, no preference]

\begin{tabular}{|c|c|c|c|}
\hline Constituent & $\begin{array}{l}\text { Primary constituent } \\
\text { classification }\end{array}$ & $\begin{array}{l}\text { Analytical } \\
\text { schedules }\end{array}$ & $\begin{array}{c}\text { Preferred } \\
\text { analytical schedule }\end{array}$ \\
\hline \multicolumn{4}{|c|}{ Results from preferred method reported } \\
\hline Caffeine & Wastewater indicator & 2060,2080 & 2060 \\
\hline Deethylatrazine (2-Chloro-4-isopropylamino-6-amino-s-triazine) & Pesticide degradate & 2003,2060 & 2003 \\
\hline Tebuthiuron & Pesticide & 2003,2060 & 2003 \\
\hline Alkalinity & Water-quality indicator & field, 1948 & field \\
\hline A rsenic, total & Trace element & 1948, TM L & 1948 \\
\hline Carbaryl & Pesticide & 2003,2060 & $\mathrm{np}$ \\
\hline Chromium, total & Trace element & 1948, TML & 1948 \\
\hline Iron, total & Trace element & 1948, TM L & 1948 \\
\hline Tritium & Inorganic tracer & LLNL, SITL & $\mathrm{np}$ \\
\hline
\end{tabular}

Table A3. Constituents detected in field blanks and study reporting level (SRL) analyses for the Santa Barbara study unit, January to February 2011, California GAMA Priority Basin Project.

[Sources of study reporting level (SRL): Each SRL was selected using one of the three approaches: (1) an analysis of quality-control data from M ay 2004 through September 2010 for volatile organic compounds (Fram and others, 2012), (2) an analysis of quality-control data from M ay 2004 through J anuary 2008 for trace elements (Olsen and others, 2010), or (3) the maximum concentration observed in the field blanks collected for the Santa Barbara study unit. Abbreviations: $\leq$, less than or equal to; $\mu \mathrm{g} / \mathrm{L}$, micrograms per liter; $\mathrm{mg} / \mathrm{L}$, milligrams per liter; —, not detected]

\begin{tabular}{|c|c|c|c|c|c|}
\hline Constituent & $\begin{array}{c}\text { Number of field blank detections/ } \\
\text { total number of field blanks }\end{array}$ & $\begin{array}{c}\text { Concentrations } \\
\text { detected in field blanks }\end{array}$ & $\begin{array}{c}\text { SRL } \\
\text { concentration }\end{array}$ & Source of SRL & $\begin{array}{c}\text { Number of groundwater } \\
\text { detections } \leq \text {-coded }\end{array}$ \\
\hline \multicolumn{6}{|c|}{ Volatile organic compounds (VOCs) ( $\mu \mathrm{g} / \mathrm{L})$} \\
\hline 1,2,4-trimethylbenzene & $0 / 3$ & - & 0.56 & Fram and others, 2012 & 4 \\
\hline \multicolumn{6}{|c|}{ Trace elements $(\mu \mathrm{g} / \mathrm{L})$} \\
\hline Barium & $0 / 3$ & - & 0.36 & Olsen and others, 2010 & 0 \\
\hline Chromium & $0 / 3$ & - & 0.42 & OIsen and others, 2010 & 16 \\
\hline Copper & $2 / 3$ & $1.0,1.2$ & 1.7 & Olsen and others, 2010 & 7 \\
\hline Iron & $1 / 3$ & 7.2 & 6.0 & OIsen and others, 2010 & 4 \\
\hline Lead & $3 / 3$ & $0.87,0.02,0.06$ & 0.65 & OIsen and others, 2010 & 12 \\
\hline M anganese & $3 / 3$ & $0.31,0.24,0.47$ & 0.47 & Santa Barbara field blanks & 2 \\
\hline Nickel & $0 / 3$ & - & 0.36 & Olsen and others, 2010 & 5 \\
\hline \multicolumn{6}{|c|}{ Nutrients (mg/L) } \\
\hline A mmonia, as nitrogen & $1 / 3$ & 0.013 & 0.013 & Santa Barbara field blanks & 0 \\
\hline
\end{tabular}


Table A4A. Quality-control summary for replicate analyses of organic constituents and perchlorate detected in samples collected for the Santa Barbara study unit, January to February 2011, California GAMA Priority Basin Project.

[Abbreviations: SD, percent standard deviation; RSD, percent relative standard deviation; $\leq$, less than or equal to; RL, reporting level; nv, no value in category; -, not detected]

\begin{tabular}{|c|c|c|c|c|c|c|}
\hline Constituent & $\begin{array}{c}\text { Number of } \\
\text { non- } \\
\text { detects/ } \\
\text { number of } \\
\text { replicates }\end{array}$ & $\begin{array}{c}\text { Number } \\
\text { of } \\
\text { <-coded } \\
\text { replicates }\end{array}$ & $\begin{array}{l}\text { Number of SDs } \\
\text { greater than } \\
1 / 2 R L / \text { number of } \\
\text { replicates with } \\
\text { concentration less } \\
\text { than } 5 \text { times the } R \mathbf{L}\end{array}$ & $\begin{array}{l}\text { Concentrations of } \\
\text { replicates with SDs } \\
\text { greater than } 1 / 2 \mathrm{RL} \\
\text { (environmental, } \\
\text { replicate) }\end{array}$ & $\begin{array}{l}\text { Number of RSDs } \\
\text { greater than } \\
10 \text { percent/number } \\
\text { of replicates with } \\
\text { concentration } \\
\text { greater than } \\
5 \text { times the RL }\end{array}$ & $\begin{array}{l}\text { Concentrations } \\
\text { of replicates with } \\
\text { RSDs greater than } \\
10 \text { percent } \\
\text { (environmental, } \\
\text { replicate) }\end{array}$ \\
\hline Bromodichloromethane & $2 / 3$ & nv & $0 / 1$ & nv & nv & nv \\
\hline 1,1,1-Trichloroethane & $3 / 3$ & nv & nv & nv & nv & nv \\
\hline 1,1-Dichloroethane & $3 / 3$ & nv & nv & nv & nv & nv \\
\hline Perchloroethene & $3 / 3$ & nv & nv & nv & nv & nv \\
\hline Carbon tetrachloride (tetrachloromethane) & $3 / 3$ & nv & nv & nv & nv & nv \\
\hline Dichlorodifluoromethane (CFC-12) & $3 / 3$ & nv & nv & nv & nv & nv \\
\hline \multicolumn{7}{|c|}{ Pesticides and pesticide degradates $(\mu \mathrm{g} / \mathrm{L})$} \\
\hline Simazine & $2 / 3$ & nv & $1 / 1$ &,- 0.007 & nv & nv \\
\hline \multicolumn{7}{|c|}{ Constituent of special interest $(\mu \mathrm{g} / \mathrm{L})$} \\
\hline Perchlorate & $1 / 3$ & nv & nv & nv & $0 / 2$ & nv \\
\hline
\end{tabular}


Table A4B. Quality-control summary for replicate analyses of inorganic constituents, isotope tracers, and radioactivity detected in samples collected for the Santa Barbara study unit, January to February 2011, California GAMA Priority Basin Project.

[Abbreviations: SD, percent standard deviation; RSD, percent relative standard deviation; RL, reporting level; $\mu \mathrm{g} / \mathrm{L}$, micrograms per liter; $\mathrm{mg} / \mathrm{L}$, milligrams per liter; $\leq$, less than or equal to; nv, no value in category; — not detected; $\mathrm{SiO}_{2}$, silicon dioxide]

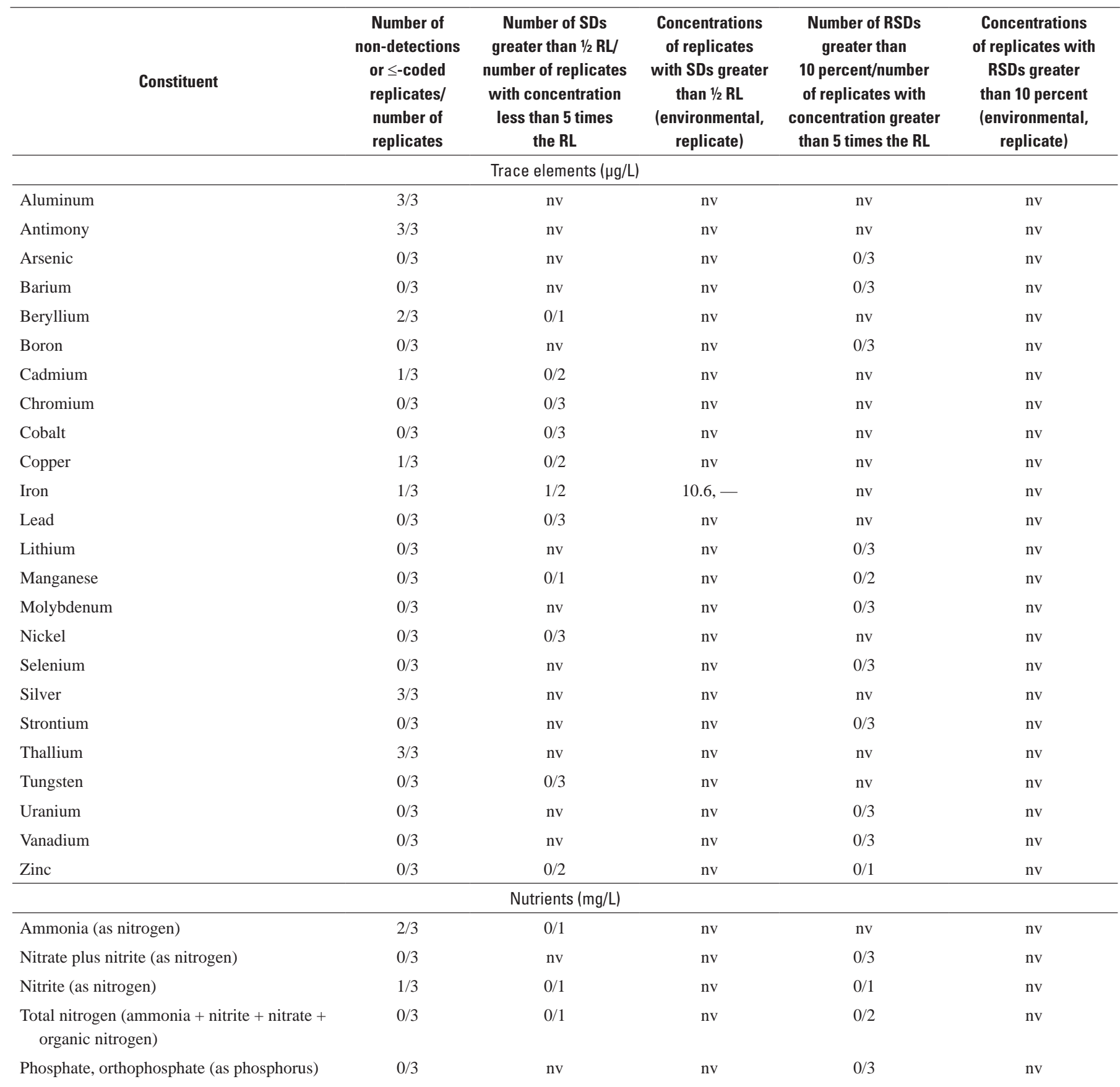


Table A4B. Quality-control summary for replicate analyses of inorganic constituents, isotope tracers, and radioactivity detected in samples collected for the Santa Barbara study unit, January to February 2011, California GAMA Priority Basin Project.—Continued

[Abbreviations: SD, percent standard deviation; RSD, percent relative standard deviation; RL, reporting level; $\mu \mathrm{g} / \mathrm{L}$, micrograms per liter; mg/L, milligrams per liter; $\leq$, less than or equal to; nv, no value in category; — not detected; $\mathrm{SiO}_{2}$, silicon dioxide]

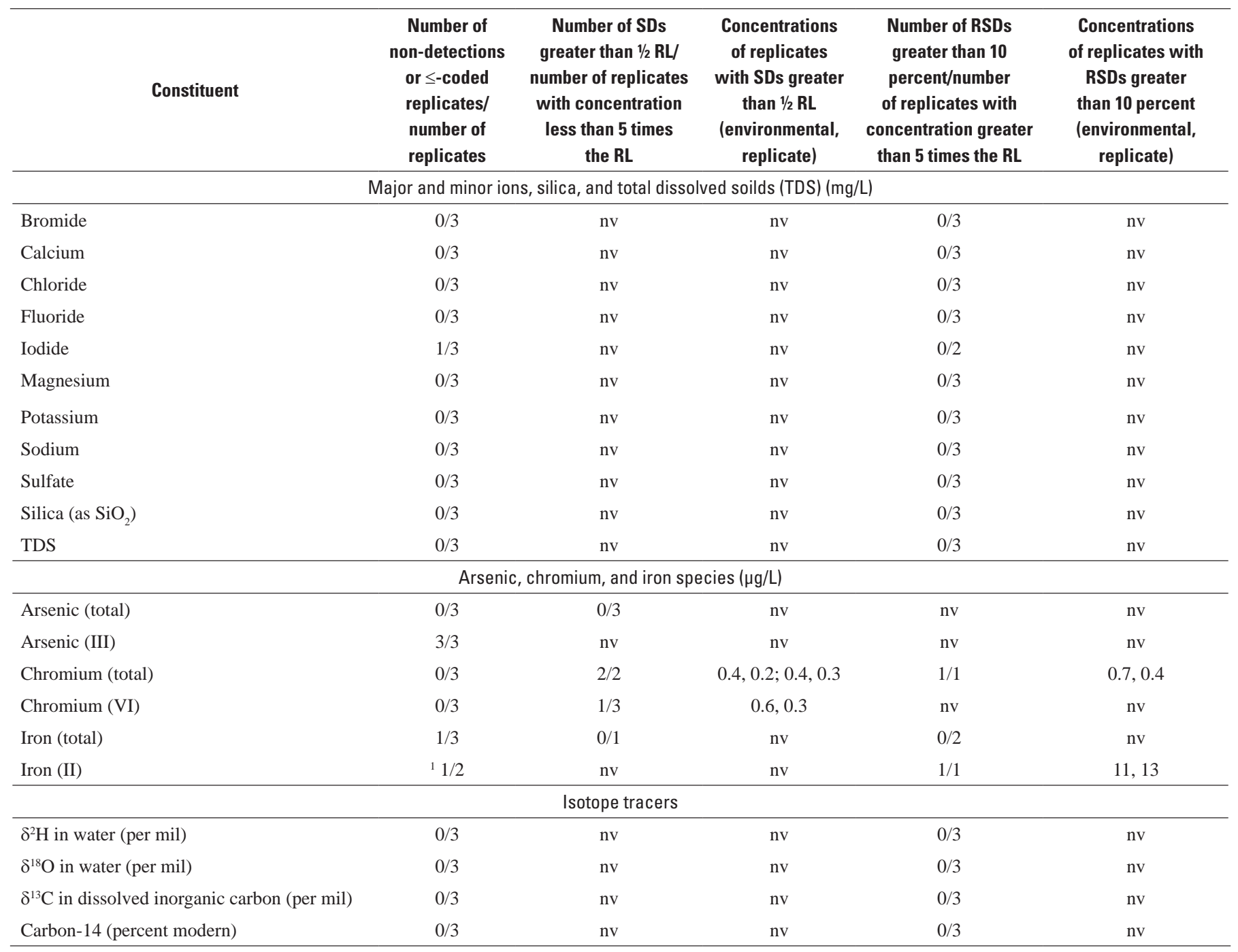

${ }^{1}$ One pair was not analyzed for iron (II) because total iron was not detected. 
Table A4C. Quality-control summary for replicate analyses of radioactive constituents detected in samples collected for the Santa Barbara study unit, January to February 2011, California GAMA Priority Basin Project.

[For activities of radiochemical constituents, a replicate pair of analyses is defined as acceptable if the normalized absolute difference (NAD) is less than 1.65, which corresponds to a significance level of 5 percent $(\alpha=0.05)$. Abbreviations: $>$, greater than; pCi/L, picocuries per liter; - , not detected; \pm , plus or minus; nv, no value in category]

\begin{tabular}{lcc}
\hline \multicolumn{1}{c}{ Constituent } & $\begin{array}{c}\text { Number of pairs } \\
\text { with NAD } \\
\text { (1.65/total number of } \\
\text { replicate pairs }\end{array}$ & $\begin{array}{c}\text { Activities for replicate pairs } \\
\text { with NAD }>\mathbf{1 . 6 5} \\
\text { (environmental, replicate) } \\
\text { (pCi/L) }\end{array}$ \\
\hline Tritium & $0 / 3$ & $\mathrm{nv}$ \\
Radon-222 & $10 / 3$ & $\mathrm{nv}$ \\
Gross al pha radioactivity, 72-hour count & $20 / 3$ & $\mathrm{nv}$ \\
Gross al pha radioactivity, 30-day count & $1 / 3$ & $- \pm 0.55,1.51 \pm 0.57$ \\
Gross beta radioactivity, 72-hour count & $20 / 3$ & $\mathrm{nv}$ \\
Gross beta radioactivity, 30-day count & $0 / 3$ & $\mathrm{nv}$ \\
\hline
\end{tabular}

${ }^{1}$ One of the replicate results was affected by a sample volume discrepancy but was within acceptable precision.

${ }^{2}$ Includes a replicate pair counted 4 days after sample collection.

Table A5A. Quality-control summary for matrix-spike recoveries of volatile organic compounds (VOCs) in samples collected for the Santa Barbara study unit, January to February 2011, California GAMA Priority Basin Project.

[A cceptable recovery range is between 70 and 130 percent]

\begin{tabular}{|c|c|c|c|c|}
\hline Constituent & $\begin{array}{c}\text { Number of } \\
\text { spike samples }\end{array}$ & $\begin{array}{c}\text { Minimum recovery } \\
\text { (percent) }\end{array}$ & $\begin{array}{c}\text { Maximum recovery } \\
\text { (percent) }\end{array}$ & $\begin{array}{l}\text { Median recovery } \\
\text { (percent) }\end{array}$ \\
\hline A cetone & 3 & 101 & 113 & 106 \\
\hline Acrylonitrile & 3 & 104 & 107 & 104 \\
\hline tert-A myl methyl ether (TA M E) & 3 & 88 & 102 & 88 \\
\hline B enzene & 3 & 101 & 105 & 102 \\
\hline B romobenzene & 3 & 92 & 100 & 92 \\
\hline B romodichloromethane ${ }^{1}$ & 3 & 92 & 95 & 94 \\
\hline B romoform (Tribromomethane) & 3 & 85 & 96 & 91 \\
\hline B romomethane (M ethyl bromide) & 3 & 70 & 102 & 84 \\
\hline n-Butylbenzene & 3 & 76 & 83 & 77 \\
\hline sec-Butylbenzene & 3 & 88 & 97 & 88 \\
\hline Chlorobenzene & 3 & 94 & 99 & 95 \\
\hline Chloroethane & 3 & 88 & 107 & 89 \\
\hline Chloroform (Trichloromethane) ${ }^{1}$ & 3 & 106 & 114 & 109 \\
\hline Chloromethane & 3 & 61 & 109 & 74 \\
\hline 3-Chloropropene & 3 & 81 & 97 & 95 \\
\hline 2-Chlorotoluene & 3 & 94 & 96 & 94 \\
\hline 4-Chlorotoluene & 3 & 90 & 100 & 95 \\
\hline Dibromochloromethane & 3 & 85 & 97 & 96 \\
\hline 1,2-Dibromo-3-chloropropane (DBCP) & 3 & 78 & 89 & 86 \\
\hline
\end{tabular}


Table A5A. Quality-control summary for matrix-spike recoveries of volatile organic compounds (VOCs) in samples collected for the Santa Barbara study unit, January to February 2011, California GAMA Priority Basin Project.—Continued

[A cceptable recovery range is between 70 and 130 percent]

\begin{tabular}{|c|c|c|c|c|}
\hline Constituent & $\begin{array}{c}\text { Number of } \\
\text { spike samples }\end{array}$ & $\begin{array}{c}\text { Minimum recovery } \\
\text { (percent) }\end{array}$ & $\begin{array}{c}\text { Maximum recovery } \\
\text { (percent) }\end{array}$ & $\begin{array}{l}\text { Median recovery } \\
\text { (percent) }\end{array}$ \\
\hline Dibromomethane $^{1}$ & 3 & 97 & 104 & 102 \\
\hline 1,2-Dichlorobenzene & 3 & 93 & 101 & 94 \\
\hline 1,3-Dichlorobenzene & 3 & 88 & 95 & 89 \\
\hline 1,4-Dichlorobenzene & 3 & 91 & 97 & 91 \\
\hline trans-1,4-Dichloro-2-butene & 3 & ${ }^{2} 14$ & 107 & 71 \\
\hline 1,1-Dichloroethane $(1,1-D C A)^{1}$ & 3 & 105 & 107 & 106 \\
\hline 1,2-Dichloroethane (1,2-DCA $)^{1}$ & 3 & 103 & 110 & 107 \\
\hline 1,1-Dichloroethene (1,1-DCE) & 3 & 93 & 106 & 97 \\
\hline cis-1,2-Dichloroethene (cis-1,2-DCE) & 3 & 92 & 99 & 93 \\
\hline trans-1,2-Dichloroethene (trans-1,2-DCE) & 3 & 96 & 100 & 96 \\
\hline 1,1-Dichloropropene & 3 & 87 & 94 & 89 \\
\hline cis-1,3-Dichloropropene & 3 & 70 & 96 & 92 \\
\hline trans-1,3-Dichloropropene & 3 & 67 & 89 & 88 \\
\hline Diethyl ether & 3 & 98 & 104 & 102 \\
\hline Diisopropyl ether (DIPE) & 3 & 91 & 103 & 92 \\
\hline Ethylbenzene & 3 & 92 & 99 & 94 \\
\hline Ethyl tert-butyl ether (ETBE) & 3 & 92 & 97 & 94 \\
\hline Ethyl methacrylate & 3 & 90 & 91 & 91 \\
\hline 0 -E thyl toluene (1-Ethyl-2-methyl benzene) & 3 & 92 & 104 & 93 \\
\hline M ethyl acrylate & 3 & 94 & 104 & 99 \\
\hline M ethyl acrylonitrile & 3 & 100 & 107 & 101 \\
\hline M ethyl tert-butyl ether (M TBE) ${ }^{1}$ & 3 & 101 & 105 & 104 \\
\hline M ethyl iso-butyl ketone (MIBK) & 3 & 99 & 103 & 102 \\
\hline M ethylene chloride (Dichloromethane) & 3 & 104 & 109 & 105 \\
\hline M ethyl ethyl ketone (2-butanone, MEK) & 3 & 100 & 108 & 103 \\
\hline M ethyl methacrylate & 3 & 92 & 93 & 92 \\
\hline Naphthalene & 3 & 88 & 96 & 89 \\
\hline Perchloroethene (PCE, Tetrachloroethene) ${ }^{1}$ & 3 & 123 & 139 & 130 \\
\hline n-Propylbenzene & 3 & 85 & 95 & 86 \\
\hline Styrene & 3 & 88 & 92 & 92 \\
\hline 1,1,1,2-Tetrachloroethane & 3 & 94 & 97 & 94 \\
\hline 1,1,2,2-Tetrachloroethane & 3 & 96 & 100 & 99 \\
\hline Tetrahydrofuran & 3 & 94 & 104 & 96 \\
\hline
\end{tabular}


Table A5A. Quality-control summary for matrix-spike recoveries of volatile organic compounds (VOCs) in samples collected for the Santa Barbara study unit, January to February 2011, California GAMA Priority Basin Project.-Continued

[A cceptable recovery range is between 70 and 130 percent]

\begin{tabular}{|c|c|c|c|c|}
\hline Constituent & $\begin{array}{c}\text { Number of } \\
\text { spike samples }\end{array}$ & $\begin{array}{l}\text { Minimum recovery } \\
\text { (percent) }\end{array}$ & $\begin{array}{c}\text { Maximum recovery } \\
\text { (percent) }\end{array}$ & $\begin{array}{l}\text { Median recovery } \\
\text { (percent) }\end{array}$ \\
\hline 1,2,3,4-Tetramethylbenzene & 3 & 85 & 99 & 87 \\
\hline 1,2,3,5-Tetramethylbenzene & 3 & 89 & 100 & 90 \\
\hline Toluene & 3 & 102 & 107 & 104 \\
\hline 1,2,3-Trichlorobenzene & 3 & 92 & 93 & 92 \\
\hline 1,2,4-Trichlorobenzene & 3 & 84 & 88 & 86 \\
\hline 1,1,2-Trichloroethane (1,1,2-TCA) & 3 & 97 & 102 & 97 \\
\hline Trichloroethene (TCE) & 3 & 92 & 97 & 94 \\
\hline Trichlorofluoromethane (CFC-11) & 3 & 102 & 113 & 105 \\
\hline 1,2,3-Trichloropropane (1,2,3-TCP) & 3 & 99 & 103 & 102 \\
\hline Trichlorotrifluoroethane (CFC-113) ${ }^{1}$ & 3 & 90 & 98 & 93 \\
\hline Vinyl bromide (B romoethene) & 3 & 90 & 107 & 94 \\
\hline Vinyl chloride (Chloroethene) & 3 & 81 & 101 & 83 \\
\hline $\mathrm{m}$ - and $\mathrm{p}$-X ylene & 3 & 93 & 101 & 95 \\
\hline $0-X$ ylene & 3 & 92 & 100 & 95 \\
\hline
\end{tabular}

${ }^{1}$ Constituents detected in groundwater samples.

${ }^{2}$ Laboratory reported that this sample had a very low recovery for trans-1,4-dichloro-2-butene due to matrix interference from sulfur in a previous sample set. 
Table A5B. Quality-control summary for matrix-spike recoveries of pesticides and pesticide degradates in samples collected for the Santa Barbara study unit, January to February 2011, California GAMA Priority Basin Project.

[A cceptable recovery range is between 70 and 130 percent]

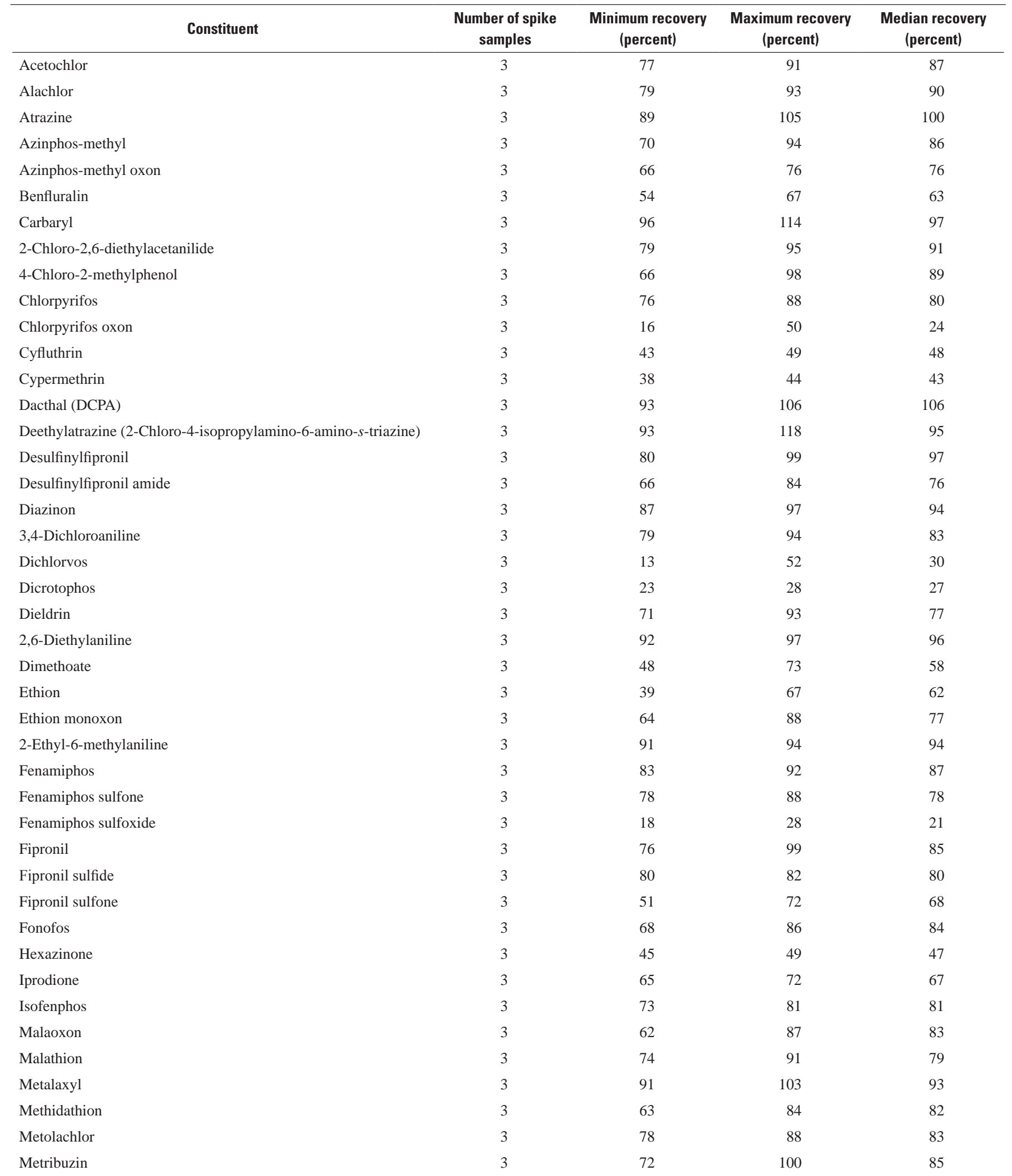


Table A5B. Quality-control summary for matrix-spike recoveries of pesticides and pesticide degradates in samples collected for the Santa Barbara study unit, January to February 2011, California GAMA Priority Basin Project._Continued

[A cceptable recovery range is between 70 and 130 percent]

\begin{tabular}{|c|c|c|c|c|}
\hline Constituent & $\begin{array}{c}\text { Number of spike } \\
\text { samples }\end{array}$ & $\begin{array}{c}\text { Minimum recovery } \\
\text { (percent) }\end{array}$ & $\begin{array}{c}\text { Maximum recovery } \\
\text { (percent) }\end{array}$ & $\begin{array}{l}\text { Median recovery } \\
\text { (percent) }\end{array}$ \\
\hline Myclobutanil & 3 & 70 & 84 & 72 \\
\hline 1-N aphthol & 3 & 33 & 75 & 47 \\
\hline Paraoxon-methyl & 3 & 50 & 76 & 68 \\
\hline Parathion-methyl & 3 & 84 & 99 & 93 \\
\hline Pendimethalin & 3 & 83 & 108 & 85 \\
\hline Phorate & 3 & 57 & 70 & 66 \\
\hline Phorate oxon & 3 & 71 & 92 & 73 \\
\hline Phosmet & 3 & 20 & 33 & 28 \\
\hline Phosmet oxon & 3 & 15 & 39 & 33 \\
\hline Prometon & 3 & 79 & 96 & 88 \\
\hline Tebuthiuron & 3 & 116 & 148 & 117 \\
\hline Terbufos & 3 & 53 & 78 & 69 \\
\hline Terbufos oxon sulfone & 3 & 48 & 75 & 74 \\
\hline Terbuthylazine & 3 & 87 & 102 & 100 \\
\hline Tribufos & 3 & 28 & 44 & 43 \\
\hline Trifluralin & 3 & 62 & 75 & 73 \\
\hline
\end{tabular}

${ }^{1}$ Constituent detected in groundwater samples. 
Table A5C. Quality-control summary for matrix-spike recoveries of polar pesticides and degradates in samples collected for the Santa Barbara study unit, January to February 2011, California GAMA Priority Basin Project.

[A cceptable recovery range is between 70 and 130 percent. A bbreviations: na, not available]

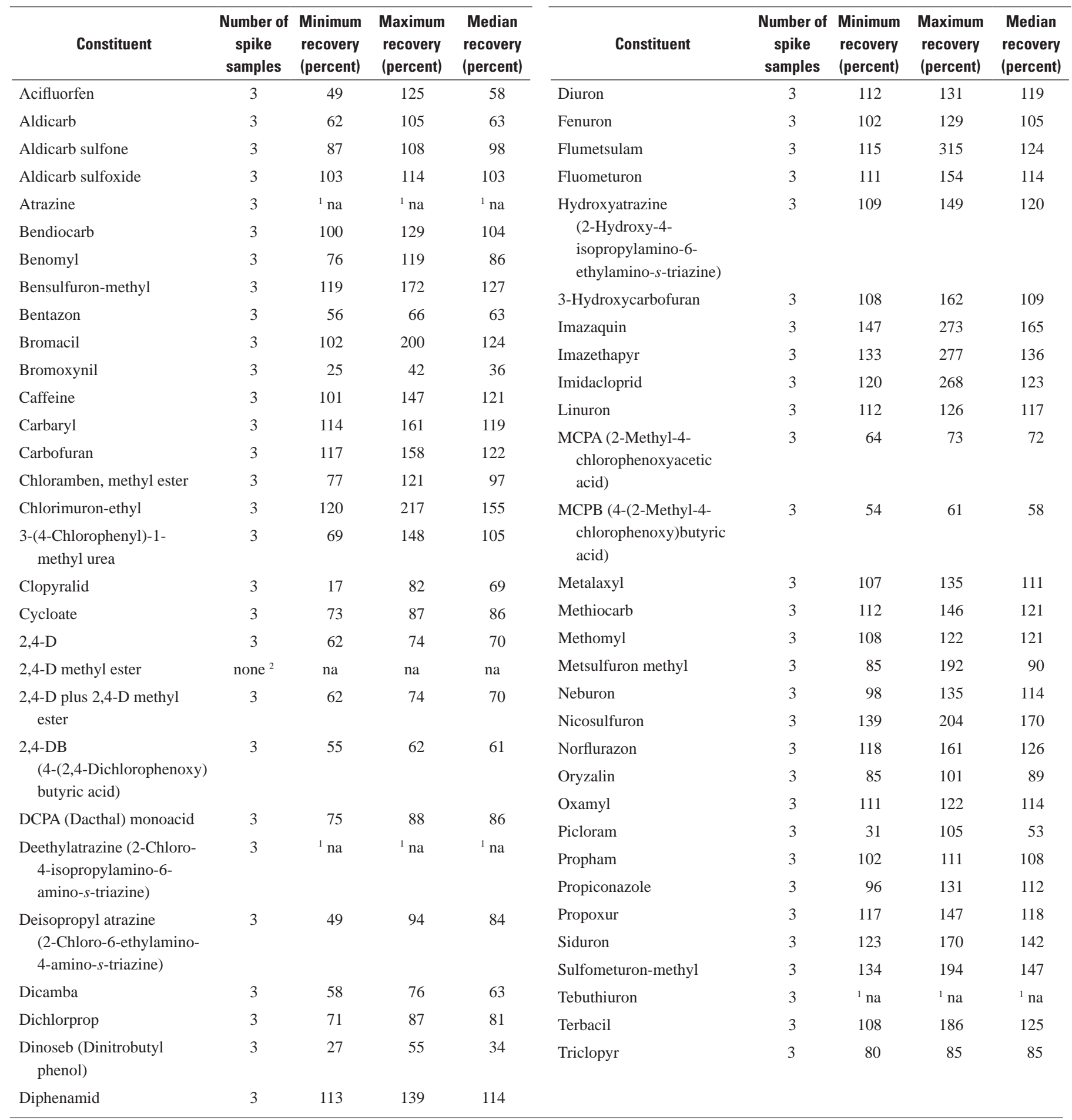

${ }^{1}$ See table A 5B for atrazine, deethylatrazine, and tebuthurion matrix-spike recoveries from the preferred method.

22,4-D methyl ester was not included in the spiking solution. 
Table A5D. Quality-control summary for matrix-spike recoveries of pharmaceutical compounds and $\mathrm{N}$-nitrosodimethylamine (NDMA) in samples collected for the Santa Barbara study unit, January to February 2011, California GAMA Priority Basin Project.

[A cceptable recovery range is between 70 and 130 percent. Abbreviations: na, not available]

\begin{tabular}{lcccc}
\hline \multicolumn{1}{c}{ Constituent } & $\begin{array}{c}\text { Number of } \\
\text { spike } \\
\text { samples }\end{array}$ & $\begin{array}{c}\text { Minimum } \\
\text { recovery } \\
\text { (percent) }\end{array}$ & $\begin{array}{c}\text { Maximum } \\
\text { recovery } \\
\text { (percent) }\end{array}$ & $\begin{array}{c}\text { Median } \\
\text { recovery } \\
\text { (percent) }\end{array}$ \\
\hline A cetaminophen & 3 & 41 & 122 & 109 \\
A lbuterol & 3 & 34 & 82 & 57 \\
Caffeine & 3 & 1 na & 1 na & 1 na \\
Carbamazapine & 3 & 81 & 107 & 89 \\
Codeine & 3 & 76 & 110 & 94 \\
Cotinine & 3 & 79 & 94 & 93 \\
Dehydronifedipine & 3 & 68 & 97 & 91 \\
Diltiazem & 3 & 14 & 32 & 23 \\
1,7-Dimethylxanthine & 3 & 81 & 108 & 94 \\
Diphenydramine & 3 & 47 & 75 & 73 \\
Sulfamethoxazole & 3 & 29 & 44 & 32 \\
Thiabendazole & 3 & 31 & 91 & 86 \\
Trimethoprim & 3 & 78 & 111 & 100 \\
Warfarin & 3 & 38 & 50 & 46 \\
N-Nitrosodimethylamine & 3 & 92 & 104 & 95 \\
$\quad$ (ND M A ) & & & & \\
\hline
\end{tabular}

${ }^{1}$ See table A 5 C for caffeine matrix-spike recoveries from the preferred method. 


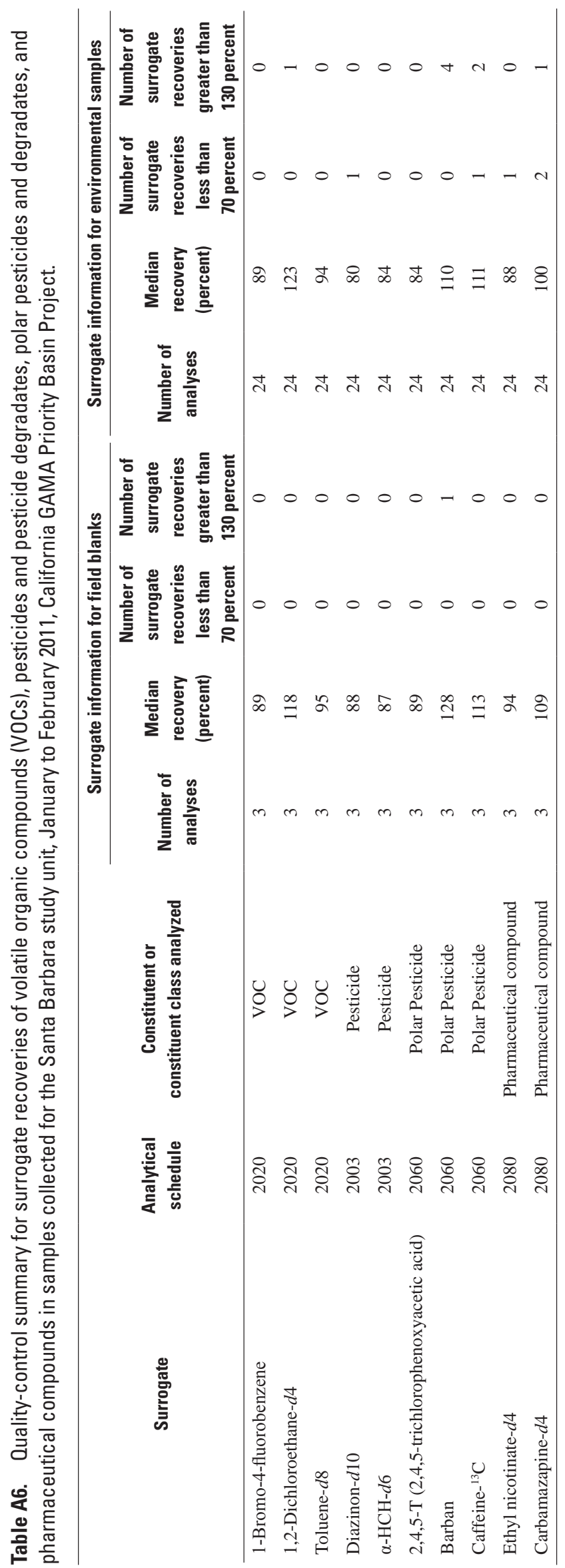


Publishing support provided by the U.S. Geological Survey Science Publishing Network, Sacramento, Tacoma, and Raleigh Publishing Service Centers

For more information concerning the research in this report, contact the

Director, California Water Science Center

U.S. Geological Survey

6000 J Street, Placer Hall

Sacramento, California 95819

http://ca.water.usgs.gov 
